\title{
EUKARYOTIC PHYTOPLANKTON COMMUNITY SPATIOTEMPORAL DYNAMICS AS IDENTIFIED THROUGH GENE EXPRESSION WITHIN A EUTROPHIC ESTUARY
}

\author{
Weida Gong
}

A thesis submitted to the faculty at the University of North Carolina at Chapel Hill in partial fulfillment of the requirements for the degree of Master of Science in the Marine Sciences Department in the College of Arts and Sciences.

Chapel Hill

2017

Approved by:

Adrian Marchetti

Hans Paerl

Marc Alperin

Scott Gifford 
(C) 2017

Weida Gong

ALL RIGHTS RESERVED 


\begin{abstract}
Weida Gong: Eukaryotic phytoplankton community spatiotemporal dynamics as identified through gene expression within a eutrophic estuary

(Under the direction of Adrian Marchetti)

Estuaries are highly dynamic and productive environments. A clear understanding of how phytoplankton, supporting the base of the food web, respond to spatiotemporal dynamics is necessary to ensuring the health and sustainability of these ecosystems. Over the span of a year, we investigated the interactions between biotic and abiotic factors within the eutrophic Neuse River Estuary (NRE). Through metatranscriptomic sequencing in combination with water quality measurements, we show that there are different metabolic strategies deployed along the NRE, and nitrogen availability is the main driving factor for such divergence. In the upper estuary, phytoplankton express more transcripts of genes for synthesis of cellular components and carbon metabolism whereas in the lower estuary, transcripts allocated to nutrient metabolism and transport were more highly expressed. We advocate for the use of molecular sequencing approaches to complement coastal water quality monitoring programs as a way to examine microbial community dynamics in response to changing environmental conditions.
\end{abstract}




\section{ACKNOWLEDGMENTS}

I want to thank J. Browne, J. Braddy and other members of the ModMon Team who assisted with sample collection and analysis. I am grateful to H. Masters for assistance with RNA extractions and C. Stackhouse and J. Roach for assistance with sequence analysis. I also thank N. Cohen, C. Moreno and R. Lampe for their assistance in the development of the bioinformatics pipeline. UNC Research Computing generously provided cluster time for sequence analysis. ModMon is funded by NC-Dept. of Environment and Natural Resources, Division of Water Resources, the Lower Neuse Basin Association and Neuse River Compliance Association and National Fish and Wildlife Foundation. This research was supported by NC Sea Grant projects R/12-HCE-3 - NA10OAR4170080 and R/14-HCE-2 - NA14OAR4170073 to A.M. and H.P. as well as start-up funds to A.M. 


\section{TABLE OF CONTENTS}

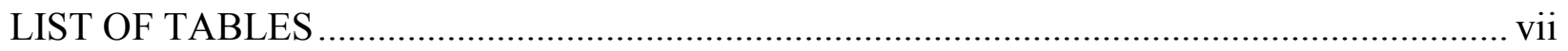

LIST OF FIGURES ….............................................................................................. viii

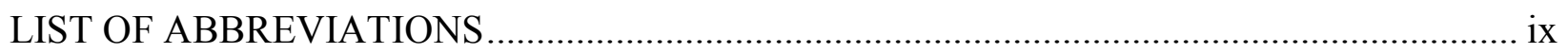

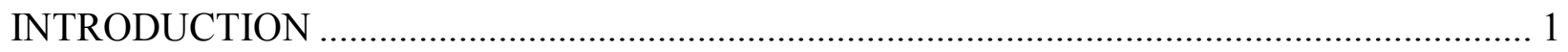

MATERIALS AND METHODS ................................................................................... 5

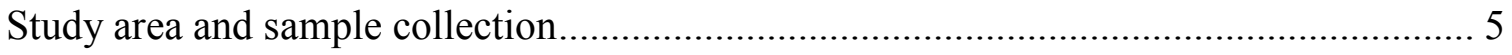

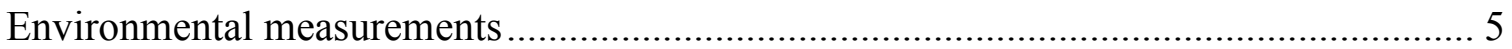

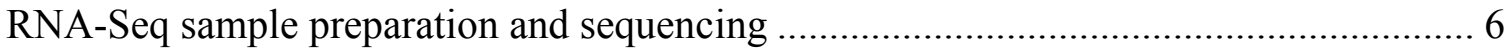

Sequence assembly, taxonomic identification and functional gene annotation pipeline .... 7

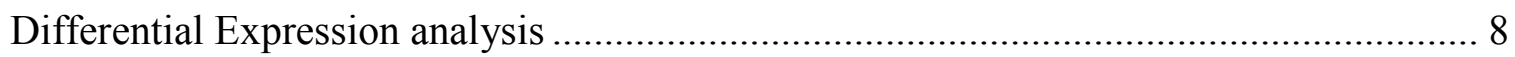

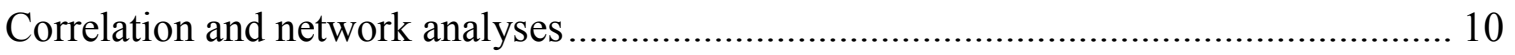

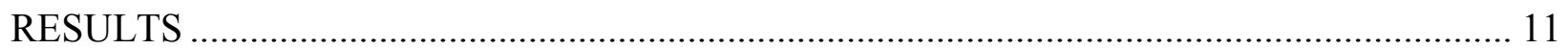

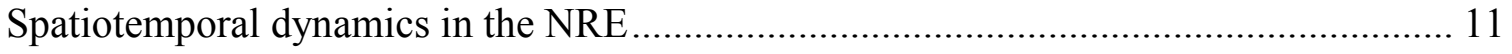

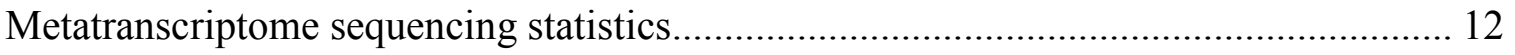

Taxonomic annotation and patterns of gene expression in the NRE .......................... 12

Gene expression differences between the upper and lower estuary ............................ 16

Correlations between metabolic functions and environmental factors .......................... 19

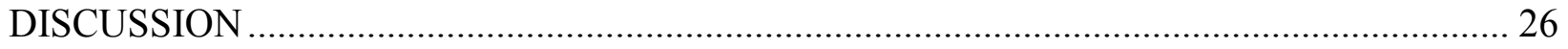

APPENDIX 1: SRA ACCESSION NUMBERS ….......................................................... 32

APPENDIX 2: CUSTOM TAXONOMIC LOOK-UP TABLE …........................................... 33 
APPENDIX 3: RESULT OF DIFFERENTIAL EXPRESSION ANALYSIS

APPENDIX 4: MA PLOT BETWEEN UPPER AND LOWER STATIONS .......................... 50

APPENDIX 5: HEATMAP FOR EXPRESSION PROFILES .............................................. 51

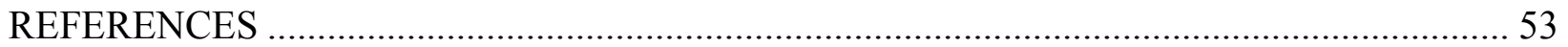




\section{LIST OF TABLES}

Table 1. Environmental parameters measured during the metatranscriptomic sampling events ... 14

Table 2. Statistics of sequencing, assembly, and quality metrics ....................................... 17

Table 3. Enrichment analysis on KEGG clas3 ..................................................................... 23 


\section{LIST OF FIGURES}

Figure 1. Physical, chemical and biological properties in the NRE ........................................ 13

Figure 2. Taxonomic annotation and patterns of gene expression in the NRE .......................... 18

Figure 3. Gene expression differences between the upper and lower estuary .............................20

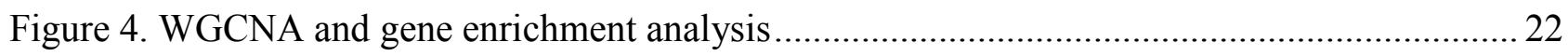

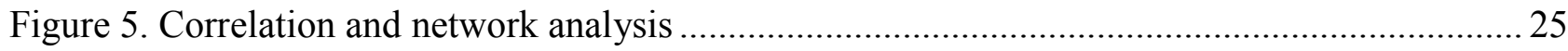




\section{LIST OF ABBRREVIATIONS}

\begin{tabular}{|c|c|}
\hline Chl $a$ & chlorophyll $a$ \\
\hline $\mathrm{Fe}$ & iron \\
\hline $\mathrm{FeT}$ & iron(III) transport system \\
\hline KO & KEGG Orthology \\
\hline MMETSP & Marine Microbial Eukaryote Transcriptome Sequencing Project \\
\hline ModMon & Neuse River Estuary Modeling and Monitoring \\
\hline$M S T$ & putative multiple sugar transporters \\
\hline$N-g l y c a n$ & N-glycan biosynthesis \\
\hline $\mathrm{NO}_{3} \mathrm{As}$ & nitrate assimilation \\
\hline$N R$ & nitrate reduction \\
\hline$N R E$ & Neuse River Estuary \\
\hline$P C A$ & principal component analysis \\
\hline $\mathrm{PO}_{4} \mathrm{~T}$ & phosphate transport system \\
\hline$P S$ & photosynthesis \\
\hline PSR & phosphate starvation response system \\
\hline$S S T$ & putative simple sugar transport system \\
\hline UreaT & urea transport system \\
\hline$W G C N A$ & Weighted Gene Co-expression Network Analysis \\
\hline
\end{tabular}




\section{INTRODUCTION}

Estuaries are semi-enclosed water bodies that link freshwater to marine environments. Cross-estuary and along estuary gradients contribute to strong spatial differences in nutrient profiles (Reed et al. 2004). The highly dynamic hydrological and nutrient cycling properties result in a significant amount of biological variation. Steep spatial gradients often make the upper and lower sections of estuaries very different environments. Apart from spatial variation, temporal variation in precipitation, temperature, wind patterns, and turbidity also contribute to the dynamic nature of estuaries (Hall et al. 2012; Paerl et al. 2014; Day et al. 2012; Peierls et al. 2012). The temporal and spatial variations force biotic components of the ecosystem, including the critically-important phytoplankton which support the base of the estuarine food web, to vary in composition and physiology depending on the environmental conditions. In the Neuse River Estuary (NRE), phytoplankton decrease $\mathrm{NO}_{3}{ }^{-}$uptake along the NRE and depend primarily on recycled $\mathrm{N}$ forms such as ammonium/urea in the lower estuary (Twomey et al. 2005). In summer, phytoplankton increase ammonium utilization in the lower estuary due to the high seasonal stratification-induced remineralization (Twomey et al. 2005; Paerl et al. 1998). This hydrological variability is also reflected in the seasonal pattern of phytoplankton community composition. For example, dinoflagellates are usually a significant part of the community in spring while cyanobacteria can be dominant in summer (Paerl et al. 2010).

Phytoplankton communities in estuaries are directly affected by exogenous nutrient inputs. Increases in anthropogenic-derived nutrients in the past century have led to massive eutrophication and increased frequency and intensity of algal blooms in estuaries around the 
globe (Howarth et al. 1997; Nixon 1995). Increases in natural perturbations such as storms have also contributed to the sporadic nutrient loading in estuaries (Paerl 2006). In fact, anthropogenic nutrient inputs can sometimes be overshadowed by climatic events such as intense storms and hurricanes (Paerl et al. 2010; Paerl et al. 2014). Nutrient loading directly affects phytoplankton communities through increased phytoplankton growth, however, the relationship between nutrient loading and phytoplankton dynamics is complex and often non-linear due to the profound interplay between biological, chemical and physical properties throughout the water column (Peierls et al. 2012; Paerl et al. 2014).

Environmental conditions are quite different along the axis of the NRE. In the upper estuary, the "geochemical filter" caused by flocculation and aggregation of humic acids and metal ions sometimes can lead to light being a limiting factor for phytoplankton growth (Sharp et al. 1984). As this upper section is quite narrow, flow rates are typically high, especially in winter and early spring. Elevated riverine discharge increases nutrient loading and provides a favorable environment for phytoplankton growth. However, when discharge is too high, nutrient loading exceeds phytoplankton's assimilatory and growth rates and advective losses overwhelm production rates so that phytoplankton abundance decreases (Hall et al. 2012). Noticeably, these residual nutrients can be utilized during low flow periods and can sometimes contribute to high phytoplankton biomass in the lower estuary (Paerl et al. 1995; Paerl et al. 2014). As the NRE widens down estuary, water residence time increases. Phytoplankton's assimilatory capacity exceeds the flushing rate, and with sporadic nutrient loading, blooms frequently occur. The relationship between nutrient loading and the phytoplankton community is more complex if biotic components, such as grazing pressure, are also considered (Walz \& Welker 1998; Brussaard 2003; Cloern 2001). 
Phytoplankton community composition also varies spatiotemporally within the estuary as different phytoplankton groups can often display distinct responses to a similar set of environmental conditions. Diatoms, dinoflagellates, cryptophytes, chlorophytes and cyanobacteria are all represented in the NRE (Pinckney et al. 1998), and can display diverse responses to hydrographic conditions. Dinoflagellate blooms are common as their relatively large size and low susceptibility to grazing provide them with a competitive advantage. Their motility also plays an important role in winter/early spring when riverine discharge is high (Graham \& Strom 2010; Demir et al. 2008; Walz \& Welker 1998; Hall \& Pearl 2011). Other than dinoflagellates, cryptophyte and chlorophyte blooms occur throughout the year, primarily coinciding with sporadic nutrient inputs (Hall et al. 2012). In summer months when temperature is high, phytoplankton that have high intrinsic growth rates at elevated temperatures, such as cyanobacteria and chlorophytes, can be abundant (Paerl et al. 1995). Diatoms have high maximum intrinsic growth rates (Smayda 1997) and are also a major component of the phytoplankton community in the NRE, although blooms rarely occur (Pinckney et al. 1998). Unlike dinoflagellates and cryptophytes, diatoms are only weakly linked to riverine inputs and are mostly affected by resuspension frequency (Hall et al. 2012).

Massive nutrient inputs and contemporaneous climatic events pose a severe threat to estuarine water quality and phytoplankton communities (Kennish \& Paerl 2010). To understand how phytoplankton respond to these anthropogenic and natural perturbations, efforts have been made to study the correlation between phytoplankton communities and environmental parameters in the NRE (Paerl et al. 2014; Pinckney et al. 1997; Hall et al. 2012). Bulk plankton community analyses (e.g., chl $a$, primary productivity, nutrient uptake rates, etc.) and water quality measurements incorporated into models to study estuarine phytoplankton dynamics have 
been informative (Carstensen et al. 2007; Pinckney et al. 1997). However, the correlation can sometimes be masked due to the interplay among spatiotemporal dynamics in the system. For example, typically pulses of DIN cause the most significant increase in phytoplankton abundance in the NRE, however there can be periods of high phytoplankton biomass without preceding DIN pulses, and chl $a$ can sometimes be negatively correlated with DIN (e.g., Peierls et al. 2012). Thus, such uncertainties in phytoplankton dynamics based of bulk measurements pose a serious challenge to understanding phytoplankton responses to environmental gradients. Knowledge on the physiology of taxonomic subsets within the plankton community can be informative to detecting distinct responses to environmental gradients and is needed to provide a more comprehensive view to better manage our valuable estuaries and coastal environments.

Metatranscriptomics has proven to be a powerful tool to provide insights into the inferred metabolic physiology of marine plankton within mixed natural assemblages (Cooper et al. 2014; Marchetti et al. 2012). Here, we have conducted a yearlong metatranscriptomic analysis of the plankton communities along a transect in the NRE. Results indicate phytoplankton communities displayed different response patterns to the steep nutrient gradients between the upper and lower estuary, and that different phytoplankton groups generally used similar strategies in such responses. 


\section{MATERIALS AND METHODS}

Study area and sample collection.

Sampling for this study took place in 2012 in conjunction with the Neuse River Estuary Modeling and Monitoring (ModMon) Program (http://www.unc.edu/ims/neuse/modmon) run by the Institute of Marine Sciences, UNC-Chapel Hill and the North Carolina Department of Environmental and Natural Resources (now Deprtment of Environmental Quality) that has collected water samples in the NRE on a bimonthly or monthly basis since 1994.

Metatranscriptomic sampling at four of the 11 routinely sampled stations (Modmon stations 20, 70,120 and 180) were performed in conjunction to the field physical-chemical measurements collected as part of the ModMon program (Fig. 1B).

\section{Environmental measurements.}

Vertical profiles of temperature, salinity, dissolved oxygen, in vivo fluorescence and light were collected with a YSI 6000 multiprobe sonde coupled to a LiCor LI-1925A quantum sensor that records photosynthetically active radiation (PAR; 400-700 nm) (Yellow Springs, Inc., Yellow Springs, $\mathrm{OH}, \mathrm{USA}$ ). Soluble nutrients (including nitrite/nitrate $\left[\mathrm{NO}_{2}^{-} \mathrm{NO}_{3}^{-}\right]$, phosphate $\left[\mathrm{PO}_{4}{ }^{3-}\right]$ and silicate $\left.\left[\mathrm{SiO}_{4}{ }^{2-}\right]\right)$, were measured using a Lachat Quick-chem 8000 auto-analyzer (Lachat, Milwaukee) as described in Peierls et al. (2012). Chl $a$ concentrations were determined using the non-acidification method of Welschmeyer (1994) on a Turner Designs Trilogy fluorometer as described in Peierls et al. (2012) and Welschmeyer (1994). Primary productivity was measured using the $\mathrm{NaH}^{14} \mathrm{CO}_{3}$ incorporation method as modified by 
Mallin and Paerl (1992). Photopigment analysis via HPLC was performed as described by Pinckney et al. (1996) except that the analyses were performed on a Shimadzu LC-20AB HPLC coupled to a Shimad SPD M20A in-line photodiode array spectrophotometer (Shimadzu Inc. USA) (Pinckney et al. 1996).

\section{RNA-Seq sample preparation and sequencing.}

Metatranscriptomic sampling occurred in the months of February, April, June, August and December of 2012 to encompass the seasonal succession of the phytoplankton assemblages in the NRE. Near surface ( $\sim 0.2 \mathrm{~m}$ depth) samples for RNA were collected and immediately filtered onto multiple Millipore isopore membrane filters $(0.45 \mu \mathrm{m}, 142 \mathrm{~mm})$ per station directly using a 3-head Masterflex L/S peristaltic pump with pre-rinsed Tygon tubing and screened from direct sunlight. Filters were changed every 15 minutes or when the flow of water decreased due to particle clogging. Individual filters were placed in Ziploc bags, wrapped in aluminum foil, and immediately placed in liquid nitrogen. A minimum of six filters were collected from each station and sampling date. Based on pump flow rates, an estimated volume of $25 \mathrm{~L}$ was filtered per station. Onshore, filters were stored at $-80^{\circ} \mathrm{C}$ until RNA extractions were performed (typically within one month).

For RNA extractions, filters were briefly thawed on ice. RNA was extracted from individual cut-up filters using the ToTALLY RNA Kit (Ambion) according to the manufacturer's protocols with the additional step that filter pieces were first vortexed in $7 \mathrm{~mL}$ of denaturation solution containing $0.5 \mathrm{~mL}$ of glass beads and the resulting lysate was centrifuged at $8,801 \mathrm{x} g$ and $4^{\circ} \mathrm{C}$ for $3 \mathrm{~min}$. Trace DNA contamination was reduced by DNase 1 (Ambion) digestion at $37^{\circ} \mathrm{C}$ for $45 \mathrm{~min}$. Polyadenosine [poly(A)+] RNA (mRNA) was isolated with the 
MicroPoly(A) Purist Kit (Ambion) according to the manufacturer's instructions. mRNA samples from several filters at each station were then combined to achieve a minimum total of $100 \mathrm{ng}$ of mRNA. Illumina sequence library synthesis using the TruSeq mRNA Library Preparation Kit (San Diego, CA, USA) was performed at the UNC High-throughput Sequencing Facility. Samples of pooled mRNA from each time point were bar-coded and sequenced on a single lane of the Illumina HiSeq2000 platform (San Diego, CA, USA), generating between 53-123 million 100 bp paired-end reads per sample.

Sequence assembly, taxonomic identification and functional gene annotation pipeline.

FastQC was used to assess read quality (Andrews 2010). Paired-end sequence reads from each sample were individually assembled into larger transcripts (termed contigs) using ABySS v 1.3.5 with multiple k-mer sizes (from 52 to 96 with a step of 2). Using Trans-ABySS v1.4.4, contigs were filtered and merged, and reads were mapped to the merged contigs (Simpson et al. 2009; Robertson et al. 2010). The number of sequence reads that aligned to each contig was calculated with SAMtools v0.1.19, and tabulated for differential gene expression analysis using the Caroline package in R (Schruth 2013; Li et al. 2009). MarineRefII (http://ssharma.marsci.uga.edu/Lab/MarineRef2/), a custom-made reference organism database of marine microbial eukaryotes and prokaryotes (maintained by the Moran Lab at the University of Georgia, Athens) was used for taxonomical annotation that includes all sequenced transcriptomes that are part of the Marine Microeukaryote Transcriptome Project (MMETSP) (Keeling et al. 2014). A sequence similarity search of the assembled contigs against MarineRefII was performed through BLASTx (v. 2.2.28), with an $e$-value cutoff of 0.001. Only reference contigs with the lowest $e$-values were kept as best hits for subsequent analysis. Each hit's 
taxonomic ID was used as an entry to obtain taxonomic information from the NCBI Taxonomy Database. Due to discrepancies between the NCBI database and widely-used phytoplankton taxonomic ranks, a manually curated taxonomic table was used to provide consistent taxonomic classifications for organisms with best hits to the assembled contigs (Appendix 2) (Keeling et al. 2014).

For functional gene annotations, the Kyoto Encyclopedia of Genes and Genomes (KEGG) database was used as a reference database. An $e$-value cutoff of 0.001 was similarly applied for KEGG homology searches, where the sequence with the lowest $e$-value was assigned. If this sequence lacked a KEGG module annotation, the next-best sequence reference contigs were screened until a sequence with a KEGG module annotation was identified. Read counts of contigs with an assigned KEGG Orthology $(\mathrm{KO})$ identity were used for differential expression analysis. Best hit results from the taxonomic and functional gene annotation searches were then merged for each contig, along with the quantitative read count information for each sample. Assembled contigs and normalized counts at the module level for all samples were also archived (Dataset 1 and 2; http://marchettilab.web.unc.edu/data/). This final composite dataset includes a list of contigs with associated functional gene and taxonomical annotations as well as quantitative read counts (Dataset 3; http://marchettilab.web.unc.edu/data/).

\section{Differential Expression analysis.}

Samples were clustered based on sampling site (see results), and KOs were normalized using "trimmed means of M (TMM)" normalization procedure available in the edgeR package. The TMM method normalizes reads by computing a scaling factor after excluding genes that have high average counts and/or have large expression differences between samples with the 
assumption that most of the genes are not differentially expressed (Robinson \& Oshlack 2010). Principle component analyses (PCA) were used with environmental measurement data collected over a 5-year period (2007 - 2012) and TMM-normalized KO data (20 metatranscriptomic samples) to visualize the spatiotemporal variability. EdgeR was used to detect differentially expressed KOs between Station 20 (the upper station) and the lower stations by way of the MANTA package as described in Marchetti et al. (2012), and significance of differentially expressed KOs were assigned with the 'exactTest' program (Robinson et al. 2009). Normalized reads for each KO were then grouped into modules using their KO associated "Module ID". Only reads with KEGG module annotations were used for differential expression analysis. A Mann-Whitney U (MWU) test was conducted to determine which modules were significantly enriched (Nielsen et al. 2005). Modules that displayed a significant difference ( $p$-value $<0.05)$ in the combined read count ratio between stations relative to the TMM were considered either overrepresented (above TMM) or under-represented (below TMM) (Appendix 3).

Differential expression analysis was also performed on each of the four dominant eukaryotic phytoplankton functional groups (i.e., diatoms, dinoflagellates, chlorophytes and cryptophytes). KOs were grouped at the KEGG clas3 level. Phytoplankton's responses were represented by the fold change of transcripts at clas 3 level, and fold change values were then used to calculate the variances among the different phytoplankton groups. KEGG clas3 gene groupings with high variances within the upper quarter were defined as metabolic functions with different expression patterns among various phytoplankton groups. KEGG clas3 groupings with lower variances are considered as similarly expressed among groups. 


\section{Correlation and network analyses.}

To assess the correlations between gene expression patterns and environmental measurements, normalized counts of KOs were subjected to a Weighted Gene Correlation Network Analysis (WGCNA) (Langfelder \& Horvath 2008). WGCNA clusters KOs into modules (ME, designated by colors, hereafter denoted as subnetworks to avoid confusion with KEGG modules) based on their expression dissimilarity and demonstrates the correlation between each subnetwork and environmental measurements. Fisher-exact test of the binary measure of a KO's presence was then applied to identify which metabolic functions (KEGG clas3) were enriched within each subnetwork. Correlation analysis was also conducted between KEGG modules and environmental measurements using Pearson correlation with associated $p$ values assigned to construct a similarity matrix. The similarity matrix was then used to build a network map, for which each node is a KEGG module or environmental measurement and each

edge between nodes represents statistically significant correlations. Network maps were created with the R package igraph (v 1.0.0) and graphs were generated using Cytoscape (v 3.3.0, www.cytoscape.org). 


\section{RESULTS}

Spatiotemporal dynamics in the NRE

The NRE is a major tributary of North Carolina's Albemarle-Pamlico Estuarine System, the USA's largest lagoonal estuarine system (Fig. 1A). Characterized by significant seasonal/temporal and spatial variations of hydrologic processes and environmental factors, the NRE constitutes a highly dynamic ecosystem for all organisms, including phytoplankton. Salinity gradually increases from the head to the mouth of the estuary (Fig. 1B, Table 1). In contrast to the salinity profile, as high nutrient riverine runoff is diluted by low nutrient sea water along with nutrient utilization by phytoplankton, nutrient concentrations (e.g., $\mathrm{NO}_{3}{ }^{-}$and $\mathrm{PO}_{4}{ }^{3-}$ ) decrease dramatically moving downstream in the estuary (Fig. 1B, Table 1). In addition to spatial gradients, the NRE also displayed high seasonal/inter-annual variability, which is reflected by high standard deviations of nutrient concentrations particularly in the upper and mid-estuary (Fig. 1B). The high variability of environmental factors and interplay of biological and hydrological processes weakened the relationship with phytoplankton biomass - none of these environmental measurements (apart from POC, which is another indicator of biomass) had strong correlations with chl $a$ (Fig. 1C). We applied a PCA to all the samples collected between 2007 and 2012 to examine how environmental conditions differed spatiotemporally. Clusters that are representative of the lower estuary stations (station 70, 120,180) largely overlap with each other, indicative of similar environmental conditions during our sampling period (Fig. 1D). The cluster for station 20 is separated from the lower estuary stations, with nutrient concentrations being the major driver of the observed divergence (Fig. 1D). The first principle component (PC1) 
is mostly represented by the horizontal components of $\mathrm{NO}_{3}{ }^{-} / \mathrm{NO}_{2}{ }^{-}, \mathrm{NH}_{4}{ }^{+}$and salinity profiles, which are reflective of spatial variation in the NRE. The second principle component (PC2) is mainly represented by the vertical components of dissolved oxygen (DO) and temperature, which are reflective of temporal variations in the NRE (Fig. 1D). Nutrient-driven spatial gradients explain $41.7 \%$ of the variance among samples while temperature/DO-driven temporal gradients explain $27.5 \%$, indicating that spatial differences are more significant than temporal ones.

\section{Metatranscriptome sequencing statistics.}

Numbers of paired-end raw reads sequenced within each of the metatranscriptomic samples used in this study ranged between 53-123 million per sample (Table 2). Assembly of reads yielded 0.4-1.2 million contigs for each sample. Between 47-63\% and 41-56\% of raw reads had sequence similarity hits to the reference sequences in the taxonomic annotation database, MarineRefII, and functional annotation database, KEGG, respectively. Between 7-11\% of raw reads in each sequence library were mapped to KEGG reference sequences containing at least one KEGG module annotation (Table 2).

Taxonomic annotation and patterns of gene expression in the NRE.

Diatoms, dinoflagellates, chlorophytes and cryptophytes are typically the most abundant eukaryotic phytoplankton groups, each commonly contributing equally (around 20\%) to the total phytoplankton chl $a$ in the NRE (Pinckney et al. 1998). Coincidently, more transcripts were allocated to these four groups than any others, although diatom and dinoflagellate-associated transcripts were more abundant than chlorophytes and cryptophytes (Fig. 2A). Analysis of 
A

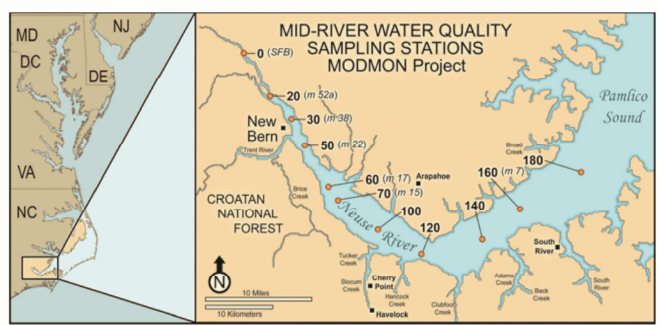

Stations

B

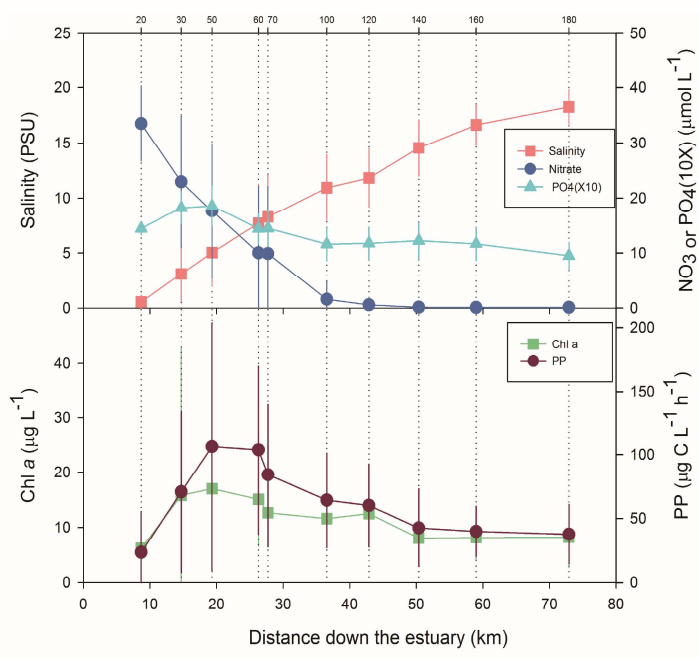

C
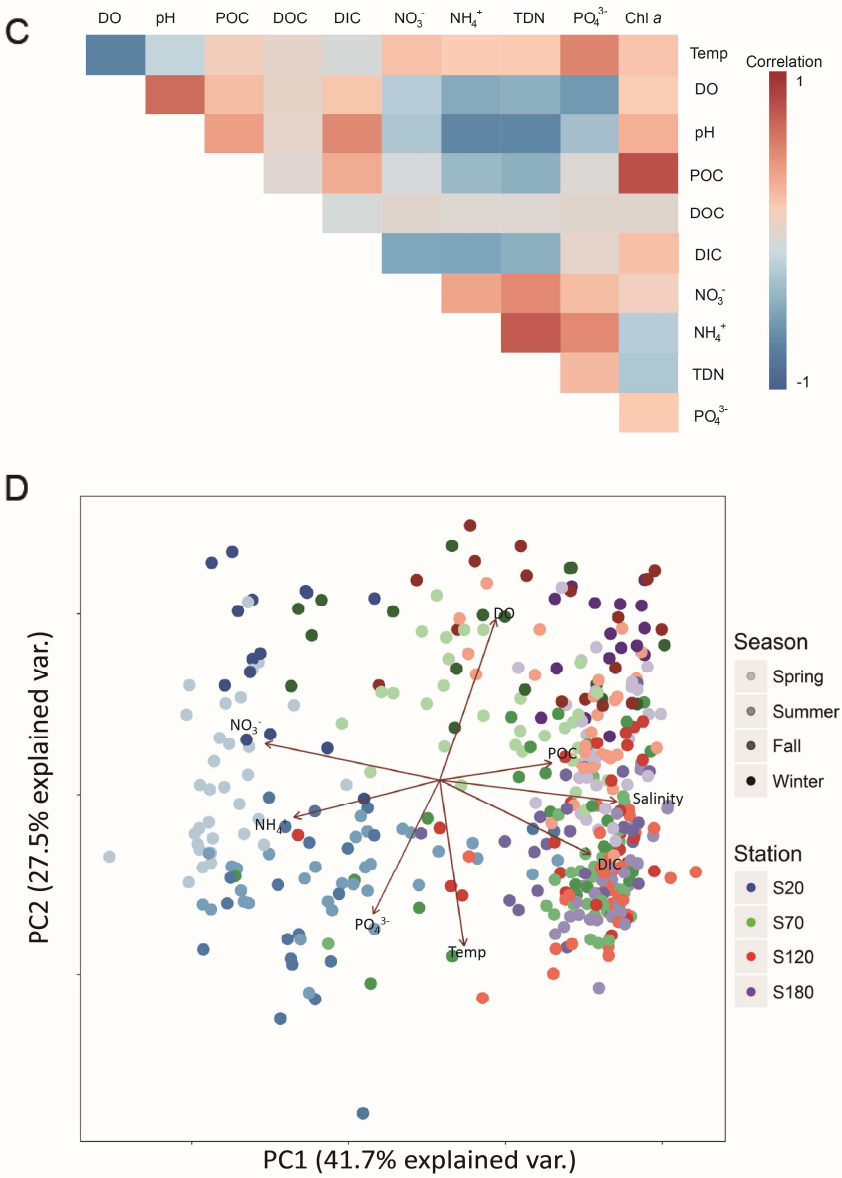

Fig. 1. Physical, chemical and biological properties in the NRE. (A) Location of ModMon stations $(20,70,120$ and 180) for metatranscriptomics sampling in the NRE. (B) Water quality parameters measured in 2012. Plotted are the annual averages and associated standard deviations of surface samples. (C) Correlations between environmental parameters measured in 2012. Temp, surface temperature; DO, dissolved oxygen; POC, particulate organic carbon; DOC, dissolved organic carbon; DIC, dissolved inorganic carbon; $\mathrm{NO}_{3}{ }^{-}$, nitrate; $\mathrm{NH}_{4}{ }^{+}$, ammonium; TDN, total dissolved nitrogen; $\mathrm{PO}_{4}{ }^{3-}$, phosphate; $\mathrm{Chl} a$, chlorophyll $a$. (D) PCA on environmental measurements from 2007-2012, with stations coded by color and seasons coded by level of shading. 
Table 1. Environmental parameters measured during the metatranscriptomic sampling events.

\begin{tabular}{cccccccc}
\hline Sampling Time & Station & Temperature $\left({ }^{\circ} \mathrm{C}\right)$ & Salinity & $\mathrm{Chl} a\left(\mu \mathrm{g} \mathrm{L}^{-1}\right)$ & $\mathrm{NO}_{3}^{-}\left(\mu \mathrm{mol} \mathrm{L}^{-1}\right)$ & $\mathrm{PO}_{4}{ }^{3-}\left(\mu \mathrm{mol}^{-1}\right)$ & $\mathrm{PPR}\left(\mathrm{mg} \mathrm{C} \mathrm{L}^{-1} \mathrm{~h}^{-1}\right)$ \\
\hline Feb & 20 & 7.74 & 0.47 & 6.90 & 40.07 & 0.95 & 5.06 \\
& 70 & 8.64 & 12.23 & 26.00 & 0.05 & 0.42 & 100.60 \\
& 120 & 7.85 & 13.73 & 9.60 & 0.03 & 0.24 & 20.37 \\
& 180 & 8.44 & 19.43 & 4.10 & 0.00 & 0.10 & 10.26 \\
Apr & 20 & 19.46 & 0.10 & 5.00 & 46.64 & 1.28 & 18.95 \\
& 70 & 16.68 & 9.30 & 10.50 & 0.00 & 0.30 & 75.57 \\
& 120 & 16.98 & 11.39 & 9.60 & 0.00 & 0.28 & 61.50 \\
& 180 & 17.48 & 18.47 & 7.40 & 0.00 & 0.13 & 54.70 \\
Jun & 20 & 24.31 & 1.09 & 6.00 & 33.93 & 1.11 & 50.88 \\
& 70 & 25.09 & 9.34 & 12.80 & 0.00 & 0.52 & 52.06 \\
& 120 & 24.09 & 9.74 & 12.80 & 0.03 & 0.62 & 71.51 \\
& 180 & 23.53 & 15.94 & 6.30 & 0.05 & 0.41 & 41.37 \\
Aug & 20 & 26.67 & 0.60 & 7.00 & 24.79 & 1.86 & 22.81 \\
& 70 & 27.17 & 7.60 & 16.10 & 11.29 & 3.68 & 220.12 \\
& 120 & 27.03 & 14.01 & 10.40 & 0.00 & 3.48 & 130.30 \\
& 180 & 27.54 & 21.51 & 5.00 & 0.00 & 2.65 & 56.82 \\
Dec & 20 & 14.76 & 1.29 & 2.50 & 21.29 & 0.93 & 3.15 \\
& 70 & 14.68 & 14.28 & 12.10 & 0.00 & 0.24 & 48.28 \\
& 120 & 14.42 & 15.67 & 6.40 & 0.00 & 0.15 & 28.09 \\
& 180 & 13.21 & 18.54 & 3.70 & 0.00 & 0.15 & 13.91 \\
\hline
\end{tabular}


Similarity (ANOSIM) was used to detect spatial/temporal differences in taxonomic composition inferred through transcript abundance of taxonomically assigned contigs in the NRE (Anderson $\&$ Walsh 2013). Taxonomic composition was significantly different spatially $(p=0.002)$ while there was not a significant difference temporally in our 2012 samples $(p=0.405)$ (Fig. 2B). The similarity percentages program (SIMPER) was then used to identify phytoplankton groups that contribute most to the spatial differences in taxonomic composition (Clarke \& Warwick 2001). Diatoms, dinoflagellates, chlorophytes and cryptophytes were found to be the top four groups that make the most contribution to such spatial variation, with transcripts associated with diatoms and dinoflagellates more abundant in the lower estuary and chlorophytes and cryptophytes more abundant in the upper estuary (Fig. 2C).

To detect whether different phytoplankton groups deploy similar strategies to adjust metabolic physiology along the NRE, we applied differential expression analysis to the four dominant eukaryotic phytoplankton functional groups. Of the four groups, gene expression profiles for diatoms were most closely clustered, while chlorophytes and cryptophytes showed the greatest variance (Fig. 2D), which suggests diatoms exhibit a less variable response to changing environmental conditions throughout the estuary when compared to the chlorophytes and cryptophytes.

For most metabolic functions, the four phytoplankton groups shared similar expression patterns along the sampled transect of the NRE. For example, all four groups highly expressed genes involved in central carbohydrate metabolism and carbon fixation at upper estuary sites while genes involved in nitrogen metabolism $\left(\mathrm{NO}_{3}{ }^{-}\right.$assimilation, $\mathrm{NO}_{3}{ }^{-}$reduction) were highly expressed at the lower estuary stations. However, there were some metabolic functions that showed distinct patterns among groups (Fig. 2E). For example, chlorophytes, unlike the other 
main phytoplankton groups, showed increased expression of genes involved in photosynthesis in the lower estuary stations.

Gene expression differences between the upper and lower estuary.

Phytoplankton metabolic physiology can be inferred through gene expression analysis. A PCA was used to examine the differences in gene expression profiles among the different sites and sampling time points. Consistent with environmental factors separating upper and lower sections of the NRE, phytoplankton gene expression in the upper estuary station (St. 20) also differed from the lower estuary stations (Fig. 3A).

Given the high degree of variability found along the NRE stations (Fig .1), we applied a TMMbased differential expression analysis to understand differences in phytoplankton's metabolic physiology between upper and lower estuary stations as perceived through gene expression patterns. Genes with a KEGG Orthology $(\mathrm{KO})$ annotation were grouped into KEGG modules to provide a more holistic analysis of patterns in gene expression. Normalized counts, fold change, and $p$-values for each module are provided in Appendix 3. Photosynthesis (M00161 Photosystem II, M00163 Photosystem I), ATP synthesis (M00158 F-type ATPase, M00160 V-type ATPase, M00162 Cytochrome b6f complex), carbohydrate metabolism (M00001 Glycolysis, M00004 Pentose phosphate pathway, M00009 Citrate cycle), carbon fixation (M00165) and ribosomes (M00177) were over-represented (i.e., increased transcript abundance) at upper stations while at the lower stations, modules for nitrate assimilation (M00615), assimilatory nitrate reduction (M00531), urea transport system (M00323), iron transport system (M00190), N-glycan biosynthesis (M00075), putative multiple sugar transporter (M00207) and putative single sugar transporter (M00221) were over-represented (Fig. 3B). Noticeably, transcripts for Crassulacean 
Table 2. Statistics of sequencing, assembly, and quality metrics.

\begin{tabular}{|c|c|c|c|c|c|c|c|c|}
\hline \multirow[b]{2}{*}{ Sample } & \multirow[b]{2}{*}{ Number Raw Reads } & \multicolumn{3}{|c|}{ Assembly } & \multicolumn{2}{|c|}{ MarineRef } & \multicolumn{2}{|c|}{ KEGG } \\
\hline & & N50 & $\begin{array}{c}\text { mapped } \\
\text { reads }\end{array}$ & $\begin{array}{l}\text { mapped } \\
\text { reads\% }\end{array}$ & $\begin{array}{c}\text { Reads } \\
\text { with hits }\end{array}$ & Reads\% & $\begin{array}{c}\text { Reads with functional } \\
\text { annotations }\end{array}$ & $\begin{array}{l}\text { Reads with functional } \\
\text { annotations } \%\end{array}$ \\
\hline Sample_1_020 & $76,546,982$ & 296 & $47,245,829$ & $61.72 \%$ & $36,945,820$ & $48.27 \%$ & $7,641,989$ & $9.98 \%$ \\
\hline Sample_1_070 & $68,114,590$ & 339 & $48,679,661$ & $71.47 \%$ & $40,930,325$ & $60.09 \%$ & $5,652,406$ & $8.30 \%$ \\
\hline Sample_1_120 & $98,163,280$ & 414 & $73,360,652$ & $74.73 \%$ & $61,556,898$ & $62.71 \%$ & $9,075,583$ & $9.25 \%$ \\
\hline Sample_1_180 & $84,547,412$ & 384 & $48,833,258$ & $57.76 \%$ & $41,330,582$ & $48.88 \%$ & $7,541,212$ & $8.92 \%$ \\
\hline Sample_2_020 & $80,153,398$ & 198 & $53,408,959$ & $66.63 \%$ & $40,696,191$ & $50.77 \%$ & $5,331,874$ & $6.65 \%$ \\
\hline Sample_2_070 & $77,195,916$ & 355 & $62,285,449$ & $80.68 \%$ & $52,091,800$ & $67.48 \%$ & $8,386,073$ & $10.86 \%$ \\
\hline Sample_2_120 & $108,465,152$ & 353 & $87,573,330$ & $80.74 \%$ & $64,068,014$ & $59.07 \%$ & $9,469,846$ & $8.73 \%$ \\
\hline Sample_2_180 & $53,484,164$ & 305 & $37,044,804$ & $69.26 \%$ & $2,396,444$ & $4.48 \%$ & $5,166,408$ & $9.66 \%$ \\
\hline Sample_3_020 & $67,497,776$ & 229 & $46,553,365$ & $68.97 \%$ & $39,333,296$ & $58.27 \%$ & $4,664,818$ & $6.91 \%$ \\
\hline Sample_3_070 & $88,682,934$ & 351 & $64,160,437$ & $72.35 \%$ & $55,802,712$ & $62.92 \%$ & $8,042,761$ & $9.07 \%$ \\
\hline Sample_3_120 & $83,132,158$ & 299 & $56,390,689$ & $67.83 \%$ & $44,495,449$ & $53.52 \%$ & $6,974,708$ & $8.39 \%$ \\
\hline Sample_3_180 & $62,073,318$ & 213 & $35,567,596$ & $57.30 \%$ & $31,625,608$ & $50.95 \%$ & $4,121,288$ & $6.64 \%$ \\
\hline Sample_4_020 & $101,367,318$ & 310 & $80,797,029$ & $79.71 \%$ & $61,911,608$ & $61.08 \%$ & $9,183,073$ & $9.06 \%$ \\
\hline Sample_4_070 & $85,816,112$ & 246 & $61,162,553$ & $71.27 \%$ & $46,484,770$ & $54.17 \%$ & $5,233,581$ & $6.10 \%$ \\
\hline Sample_4_120 & $123,064,946$ & 450 & $85,646,123$ & $69.59 \%$ & $69,918,493$ & $56.81 \%$ & $10,499,186$ & $8.53 \%$ \\
\hline Sample_4_180 & $78,494,978$ & 269 & $46,593,559$ & $59.36 \%$ & $37,111,577$ & $47.28 \%$ & $6,263,143$ & $7.98 \%$ \\
\hline Sample_6_020 & $65,853,028$ & 466 & $39,711,379$ & $60.30 \%$ & $31,063,644$ & $47.17 \%$ & $5,857,446$ & $8.89 \%$ \\
\hline Sample_6_070 & $98,742,678$ & 476 & $74,270,668$ & $75.22 \%$ & $62,047,209$ & $62.84 \%$ & $8,674,277$ & $8.78 \%$ \\
\hline Sample_6_120 & $128,778,094$ & 376 & $128,778,094$ & $79.79 \%$ & $78,068,697$ & $60.62 \%$ & $8,982,001$ & $6.97 \%$ \\
\hline Sample_6_180 & $63,402,458$ & 460 & $44,421,790$ & $70.06 \%$ & $34,340,809$ & $54.16 \%$ & $4,944,770$ & $7.80 \%$ \\
\hline
\end{tabular}


A

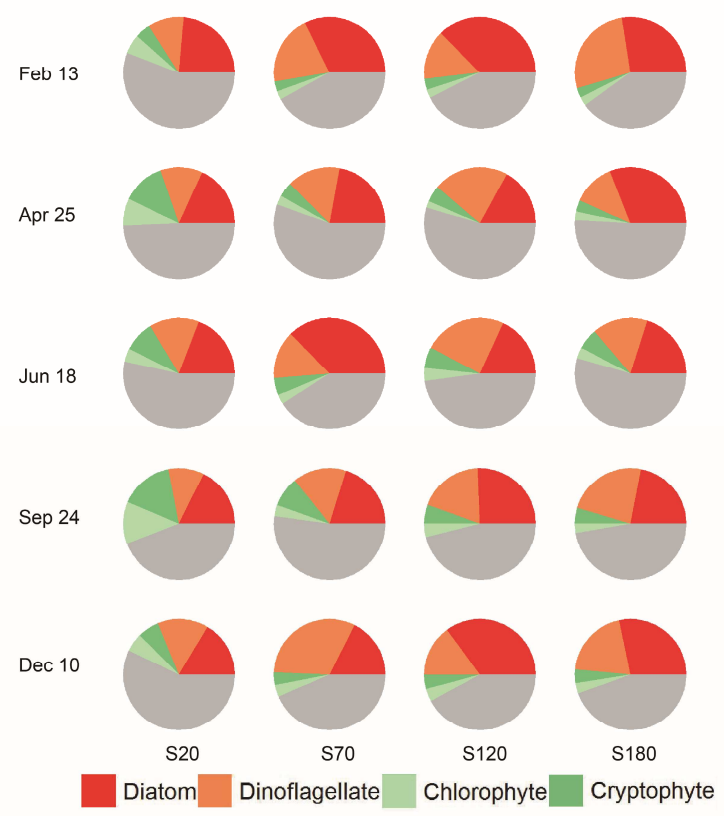

B

\begin{tabular}{ccccc}
\hline & \multicolumn{2}{c}{ Spatial } & \multicolumn{2}{c}{ Temporal } \\
\hline & $\mathrm{R}$ & $\mathrm{P}$ & $\mathrm{R}$ & $\mathrm{P}$ \\
Taxonomic & 0.3317 & 0.002 & 0.018 & 0.405 \\
\hline
\end{tabular}

C

\begin{tabular}{|c|c|c|c|}
\hline Class & \multicolumn{2}{|c|}{ Higher abundance } & Contribution \\
\hline & Upper & Lower & \\
\hline Diatoms & & $\sqrt{ }$ & 0.1668 \\
\hline Dinoflagellates & & $\sqrt{ }$ & 0.1554 \\
\hline Chlorophytes & $\sqrt{ }$ & & 0.1117 \\
\hline Cryptophytes & $\sqrt{ }$ & & 0.0833 \\
\hline
\end{tabular}

D

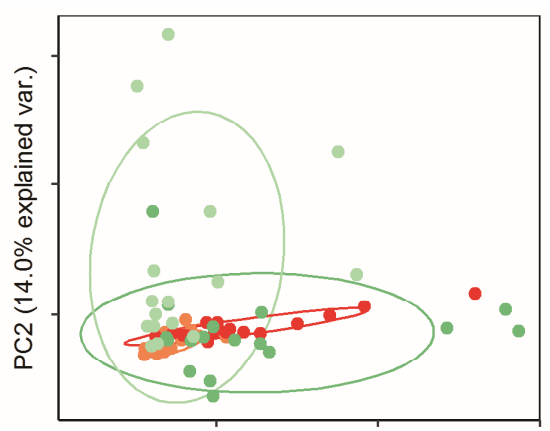

PC1 (26.7\% explained var.)

$E$

Diatom Dinoflagellate Chlorophyte Cryptophyte

Fig. 2. Taxonomic annotation and patterns of gene expression in the NRE (A) Taxonomic proportions of read counts. Grey indicates all other groups (B) Anosim on taxonomy composition. (C) Simper analysis on taxonomy composition between upper and lower estuary. (D) PCA on gene expression profiles of different phytoplankton, with taxonomy coded by color as shown in A. (E) Heatmap for differential expression analysis between upper and lower estuary stations. Each row represents the expression level of a KO with warm colors (positive fold change) indicating overrepresentation in the lower estuary stations and cooler colors (negative fold change) indicating under-representation in the lower estuary. KOs were clustered by expression similarity as follows: grey, low variances among differential expression patterns of all four major phytoplankton groups; red, orange, light green, and dark green, KOs that are differentially expressed for diatoms, dinoflagellates, chlorophytes, and cryptophytes, respectively. 
acid metabolism $(\mathrm{CAM}) / \mathrm{C}_{4}$ were detected at all sites (Appendix 3). Phosphoenolpyruvate carboxylase (PEPC), which catalyzes the first reaction in $\mathrm{CAM} / \mathrm{C}_{4}$ process, was over-represented at stations 70 and 120, and underrepresented (i.e., decreased transcript abundance) at station 20 .

\section{Correlations between metabolic functions and environmental factors}

To assess the correlations between metabolic processes, environmental factors, and sampling sites and time, expression of genes with $\mathrm{KO}$ annotations were subjected to Weighted Gene Correlation Network Analysis (WGCNA) (Langfelder \& Horvath 2008). In brief, WGCNA clusters KOs into different modules (ME, designated by colors, hereafter denoted subnetworks to avoid confusion with KEGG modules) based on expression dissimilarity, and correlations between each subnetwork and environmental factors were then used to infer relationships between functional KOs and environmental factors (Fig. 4A-B). MEmagenta and MEgreenyellow were positively correlated with nutrient concentrations (surface/bottom $\mathrm{NH}_{4}{ }^{+}$, $\mathrm{NO}_{3}{ }^{-}$and $\mathrm{PO}_{4}{ }^{3-}$ ), and $\mathrm{KOs}$ within MEmagenta and MEgreenyellow were highly expressed at station 20 (S20). There are $275 \mathrm{KOs}$ assigned into the MEmagenta group and $352 \mathrm{KOs}$ assigned to MEgreenyellow group. MEred, MEturquiose and MEblack are associated with lower estuary stations 120 and 180 (S120 and S180), and were negatively correlated with nutrient concentrations (Fig. 4A-B). There are 344, 184 and 274 KOs assigned into MEturquiose, MEred and MEbrown, respectively. Genes in each subnetwork encompass a wide spectrum of metabolic functions. A fisher-exact test enrichment analysis was applied to assess which metabolic processes are most representative of each subnetwork. KOs involved in fatty acid metabolism, carbon fixation, photosynthesis, sugar metabolism, ATP synthesis, branched-chain amino acid 
A
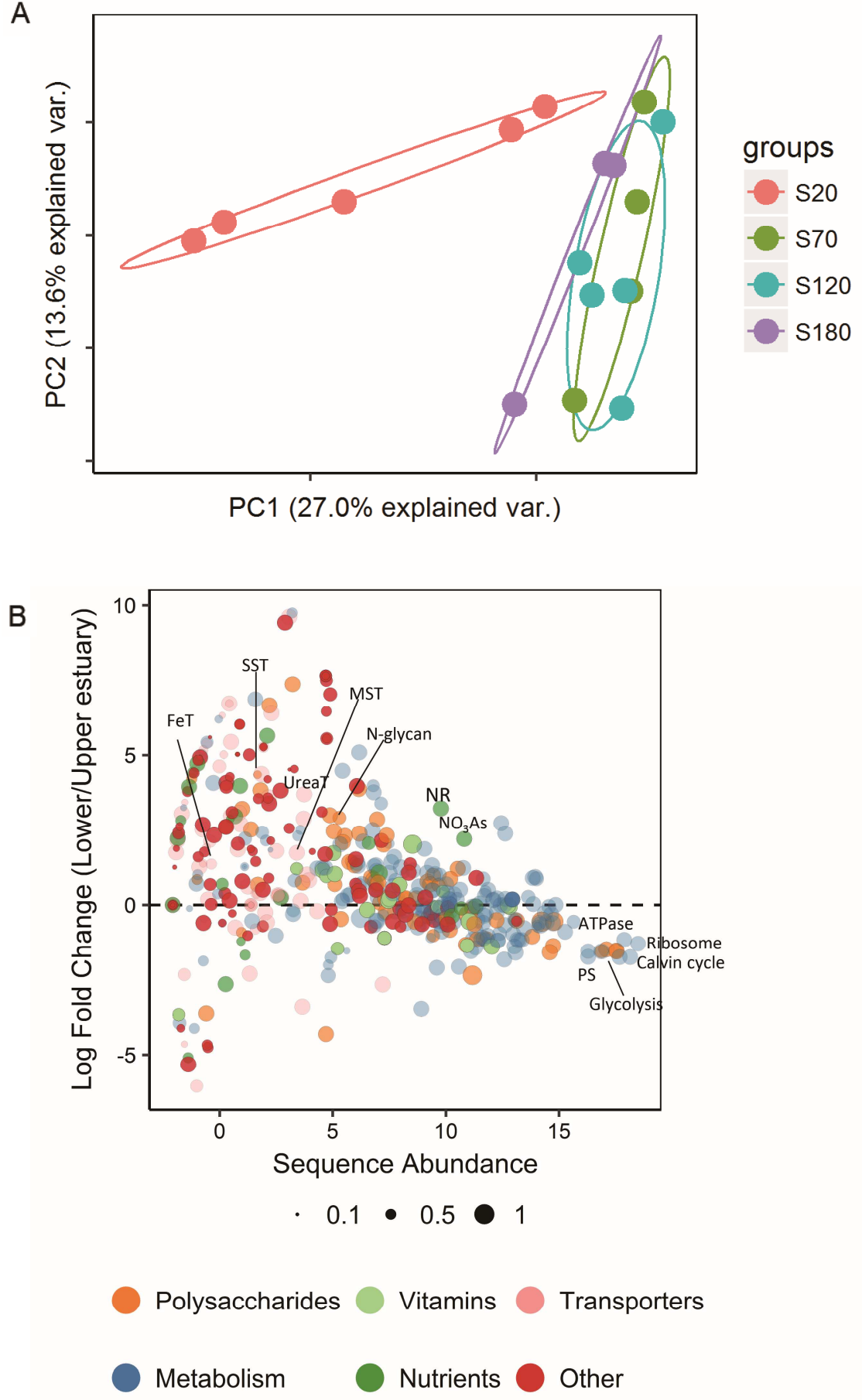

Fig. 3. Gene expression differences between the upper and lower (A) PCA of gene expression profiles of the phytoplankton community grouped by station (B) Metabolic-pathway color-coded scatter plot of log fold-change in transcript abundance between the lower and upper estuary stations. Plotted are the fold-change of module transcripts over average sequence abundance (counts per million $[\mathrm{CPM}]$ ). Modules are grouped into different categories based on their metabolic functions. Circle size indicates the percentage of enzymes/proteins in each KEGG module with reads mapping to the underlying KEGG genes. Both axes are in log scale (base 2). 
metabolism and ribosome metabolism are enriched in MEmagenta and MEgreenyellow (Fig. 4C and Table 3). KOs representing nitrogen metabolism, lipid metabolism, glycan metabolism, transcription/translation regulation mechanisms (spliceosome, RNA processing, proteasome), $\mathrm{ABC}$ transport system and saccharide, polyol and lipid transport system are enriched in MEred, MEturquiose and MEblack (Fig. 4C and Table 3).

In accordance with the KOs that are represented within each of these subnetworks (i.e., MEmagenta, MEgreenyellow, MEred, MEturquiose and MEblack), the phytoplankton responses to variations in environmental gradients along the NRE can be primarily characterized as being related to nutrient metabolism, growth metabolism, saccharide metabolism, and transport systems, grouping greater than 9500 KOs into 20 modules. Pearson correlation analysis was applied to determine how those "responsive" modules correlate with environmental factors. A negative correlation was detected between nitrogen concentrations and modules enriched with genes involved in nitrogen-related processes (i.e., $\mathrm{NO}_{3}{ }^{-}$reduction, $\mathrm{NO}_{3}{ }^{-}$assimilation, $\mathrm{NO}_{3}{ }^{-}$ transporter, urea transport system), $\mathrm{ABC}$ transport system and transporters for essential metabolites such as iron, multiple sugars, proline, phosphate and glycose (Fig. 5A). Nutrient concentrations $\left(\mathrm{NO}_{3}\right.$, surface/bottom $\mathrm{NH}_{4}$, and $\left.\mathrm{PO}_{4}\right)$ were positively correlated with modules enriched with genes involved in photosynthesis (PSI, PSII), glycolysis, photorespiration, ribosome metabolism, fatty acid synthesis, and citrate cycle (Fig. 5A). Besides correlation between modules and environmental factors, correlations within modules were also examined. Positive correlations among modules representative of transporters for various nutrients, modules involved in nitrogen-related processes and lipopolysaccharide synthesis/releasing system were identified (Fig. 5B). Photosynthesis, carbohydrate metabolisms and ATP synthesis were also detected to be co-expressed (Fig. 5C). 
A

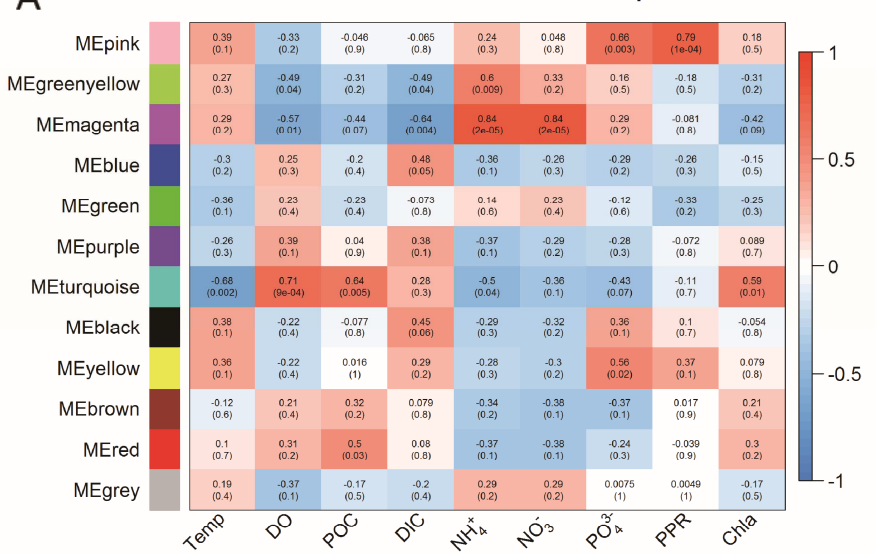

B
C

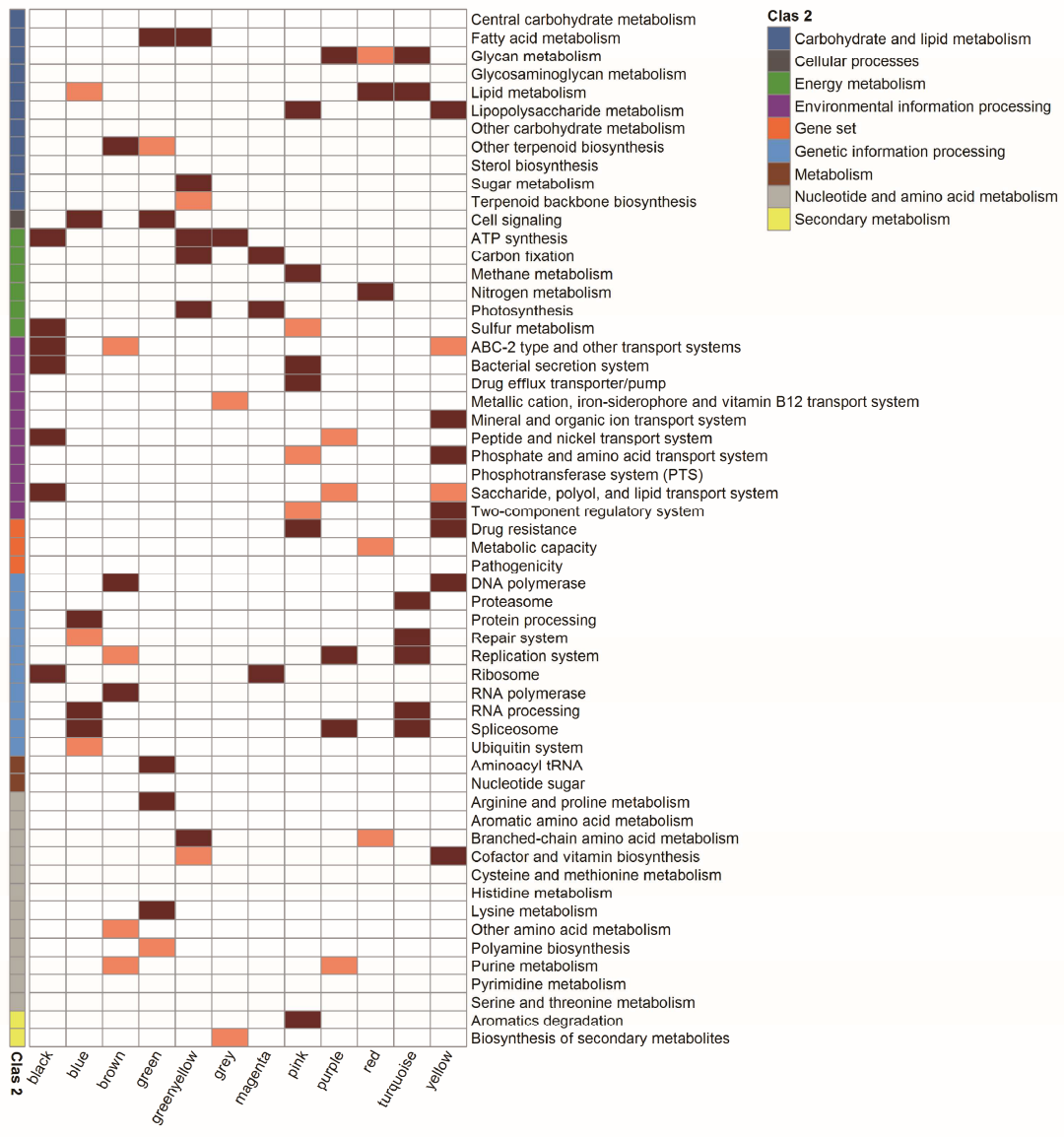

Fig. 4. WGCNA and gene enrichment analysis. Weighted Gene Co-expression Network Analysis (WGCNA) demonstrating the correlation between subnetworks and (A) environmental measurements (B) spatiotemporal identifiers. The numbers in each cell are Pearson's correlation coefficients and $p$-values of the correlation test (in brackets). Color of the cell indicates the correlation between subnetworks and corresponding parameters, with red indicating a positive correlation and blue indicating a negative correlation. (C) Heatmap for enrichment analysis shows the significance levels of whether each KEGG Clas 3 is enriched in each subnetwork, with dark red indicative of $p$-value $<0.05$, and pink indicative of $0.05<p$-value $<0.1$. KEGG Clas3 functions are sorted by KEGG Clas 2 in alphabetic order. 
Table 3: Enrichment analysis on KEGG Clas3

\begin{tabular}{|c|c|c|}
\hline KEGG Clas3 & P-value & subnetwork \\
\hline Sugar metabolism & 0.031498 & greenyellow \\
\hline Carbon fixation & 0.025377 & greenyellow \\
\hline Photosynthesis & 0.032296 & greenyellow \\
\hline ATP synthesis & $5.16 \mathrm{E}-07$ & greenyellow \\
\hline Fatty acid metabolism & 0.041549 & greenyellow \\
\hline Branched-chain amino acid metabolism & 0.000373 & greenyellow \\
\hline Ribosome & $2.25 \mathrm{E}-51$ & magenta \\
\hline Carbon fixation & 0.023032 & magenta \\
\hline Photosynthesis & 0.00084 & magenta \\
\hline RNA processing & 0.000458 & turquoise \\
\hline Spliceosome & 0.001091 & turquoise \\
\hline Proteasome & $1.32 \mathrm{E}-21$ & turquoise \\
\hline Repair system & $1.18 \mathrm{E}-06$ & turquoise \\
\hline Replication system & 0.005877 & turquoise \\
\hline Lipid metabolism & 0.025833 & turquoise \\
\hline Glycan metabolism & 0.049328 & turquoise \\
\hline Bacterial secretion system & 0.001129 & black \\
\hline ABC-2 type and other transport systems & 0.017615 & black \\
\hline Peptide and nickel transport system & $1.41 \mathrm{E}-05$ & black \\
\hline Saccharide, polyol, and lipid transport system & $5.20 \mathrm{E}-06$ & black \\
\hline Ribosome & 0.029372 & black \\
\hline Sulfur metabolism & 0.000451 & black \\
\hline ATP synthesis & 0.001319 & black \\
\hline Cell signaling & $7.00 \mathrm{E}-05$ & green \\
\hline Aminoacyl tRNA & $3.66 \mathrm{E}-05$ & green \\
\hline Fatty acid metabolism & 0.025243 & green \\
\hline Lysine metabolism & 0.009661 & green \\
\hline Arginine and proline metabolism & 0.021213 & green \\
\hline DNA polymerase & 0.001355 & brown \\
\hline RNA polymerase & 0.032672 & brown \\
\hline Other terpenoid biosynthesis & 0.028148 & brown \\
\hline Drug efflux transporter/pump & 0.00282 & pink \\
\hline Drug resistance & 0.006899 & pink \\
\hline Aromatics degradation & 0.017968 & pink \\
\hline Bacterial secretion system & 0.007337 & pink \\
\hline Methane metabolism & 0.00085 & pink \\
\hline Lipopolysaccharide metabolism & 0.01699 & pink \\
\hline Cell signaling & 0.000145 & blue \\
\hline Protein processing & 0.043808 & blue \\
\hline RNA processing & $6.02 \mathrm{E}-09$ & blue \\
\hline
\end{tabular}




\begin{tabular}{lll}
\hline Spliceosome & $1.06 \mathrm{E}-07$ & blue \\
Nitrogen metabolism & 0.004075 & red \\
Lipid metabolism & 0.023006 & red \\
ATP synthesis & 0.000208 grey \\
Drug resistance & 0.004657 yellow \\
Two-component regulatory system & 0.000763 yellow \\
DNA polymerase & 0.015433 yellow \\
Phosphate and amino acid transport system & 0.000124 yellow \\
Mineral and organic ion transport system & 0.004157 yellow \\
Cofactor and vitamin biosynthesis & 0.017866 yellow \\
Lipopolysaccharide metabolism & 0.006755 yellow \\
Spliceosome & 0.005551 purple \\
Replication system & 0.003774 purple \\
Glycan metabolism & 0.011045 purple \\
\hline
\end{tabular}


A

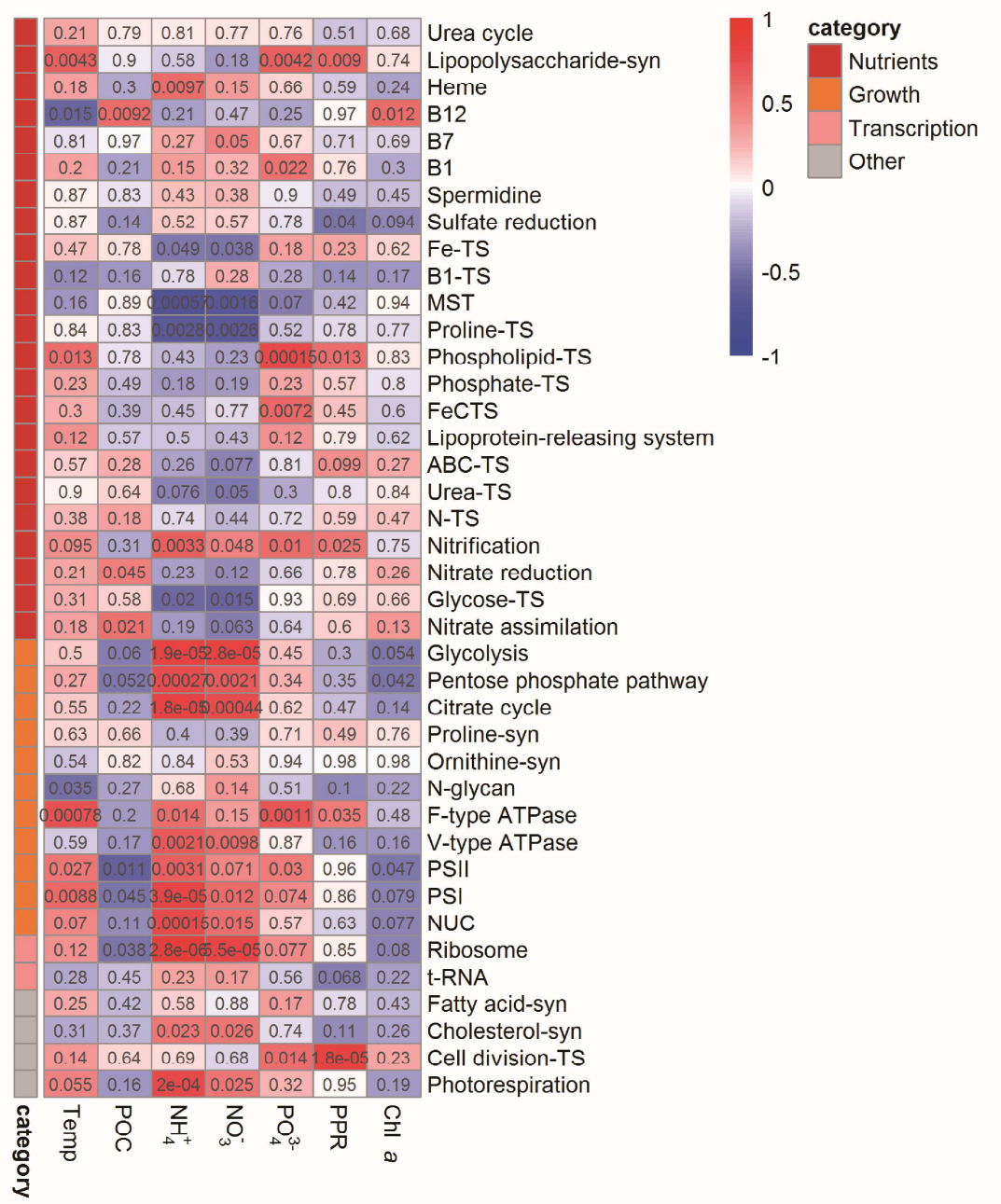

B
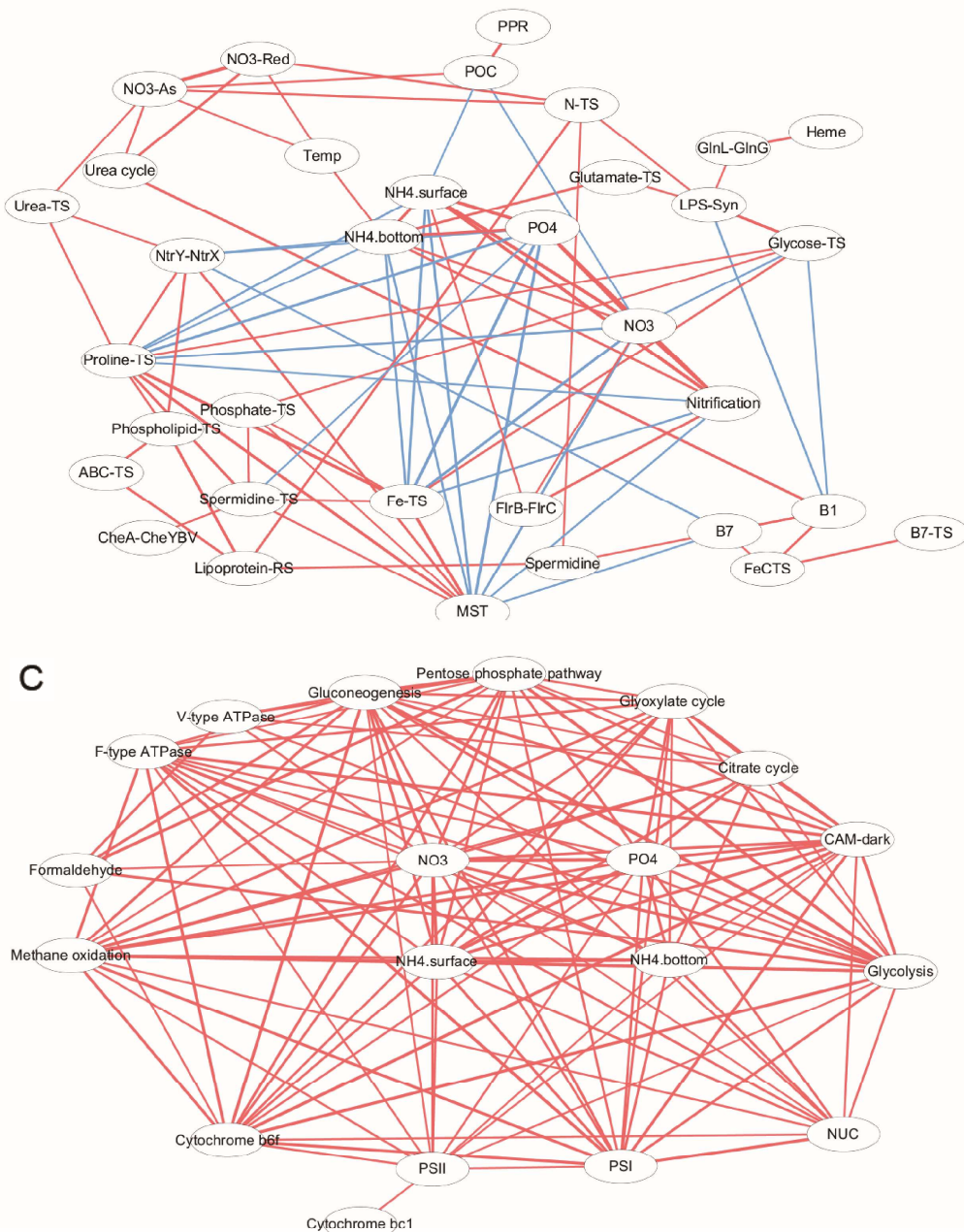

Fig. 5. Correlation and network analysis (A) Heatmap of the correlation between KEGG Modules and selected environmental factors in the NRE. Color of the cell indicates the correlation where red indicates a positive correlation and blue indicates a negative correlation. The numbers in the cells are p-values of the Pearson correlation test. Modules are sorted based on functional categories. Selected network map for (B) nutrient metabolisms and (C) growth-related metabolisms showing the co-expression patterns in KEGG modules and correlations between modules and environmental factors. Connections stand for significant ( $\mathrm{p}$-value $<0.05$ ) correlations, with red and blue indicative of positive and negative correlations, respectively. 


\section{DISCUSSION}

The NRE is a highly dynamic system characterized by steep gradients in $\mathrm{NO}_{3}^{-}$ concentrations from the upper to lower estuary (Fig. 1B). Correspondingly, nitrogen has frequently been shown to be the major limiting resource for phytoplankton with $\mathrm{NO}_{3}{ }^{-}$being the dominant inorganic source in the NRE (Piehler et al. 2004; Cira et al. 2016). Nitrogen is essential for phytoplankton growth, but nitrogen inputs are dependent on discharge rate and can be quite episodic. For example, the annual average of nitrate concentration at station 70 is approximately $10 \mu \mathrm{mol} \mathrm{L} \mathrm{L}^{-1}$, although concentrations were near or below the level of detection during four out of five metatranscriptiome sampling time points (Table 1). Given the high variability of nitrogen inputs and strong interplay between biological and hydrological processes, nitrogen $\left(\mathrm{NO}_{3}{ }^{-}\right.$and $\mathrm{NH}_{4}{ }^{+}$) along with other environmental factors were only weakly correlated with chl $a$ (Fig. 1C), and thus models based solely on these bulk measurements would have difficulty in predicting phytoplankton dynamics within the NRE.

Environmental conditions were found to be relatively similar at the three lower estuary stations (station 70, 120 and 180) while the upper estuary station (station 20) often displayed the greatest differences in water properties (Fig. 1D). Concomitantly, metabolic activity inferred through gene expression patterns also displayed many differences between the upper and lower estuary stations (e.g. Fig. 3A).

Transcript proportions of chlorophytes and cryptophytes decrease from upper to lower estuary, whereas those of dinoflagellates and diatoms slightly increase along the estuary. This spatial segregation of taxonomic groups is consistent with previous findings that freshwater 
chlorophytes are likely to be more abundant in the upper estuary due to salinity preferences (Pinckney et al. 1997; Paerl et al. 1995; Valdes-Weaver et al. 2006). Percentages of diatom transcripts in the NRE are relatively stable. Consistent with this pattern, there were minimal variations in diatom gene expression along the NRE despite the steep spatial gradients observed (Fig. 2D). Diatoms are known to have high maximum intrinsic growth rates and can become the dominant group when nutrients are supplied (Smayda 1997). Similarly within coastal upwelling zones as well as during nutrient addition experiments, diatoms often elicit a substantial gene expression response and quickly dominate the stimulated phytoplankton community (Fawcett \& Ward n.d.; Smith et al. 1992; Marchetti et al. 2012). However, in the NRE, diatoms were not any more abundant than other phytoplankton groups at upper estuary where nutrient concentrations were high, and diatom blooms were not observed frequently despite the occurrence of dinoflagellate blooms in the NRE when there are high nutrient inputs (Pinckney et al., 1998; Gong et al. 2016). Hall et al., (2012) reported resuspended diatoms from benthic environments as a major component to the diatom community that only weakly relied on "new" riverine nutrient inputs. Thus the diatom community could be inherently less affected by the spatial gradients in nutrient concentrations resulting in more stable gene expression patterns.

Divergence in gene expression profiles between upper and lower estuary stations indicated that phytoplankton in these sectors displayed different metabolic activities. Photosynthesis, ATP synthesis, carbohydrate metabolism, and carbon fixation were overrepresented in the upper estuary station, all of which are important components for phytoplankton energy production and growth. Ribosomes, which are essential for protein synthesis, were also over-represented at station 20 . The amount of ribosome transcripts has previously been shown to be positively correlated with metabolic rates and growth (Gifford et al. 
2012; Wei et al. 2001). The over-representation of these modules suggests high phytoplankton growth rates at this station, which is consistent with previous findings based on nutrient uptake kinetics that the highest growth rates occur in this section of estuary despite phytoplankton biomass not typically accumulating due to significant advective losses induced by high discharge rates (Pinckney et al. 1997). At lower estuary stations, nitrogen-related modules were overrepresented, indicative of a high nitrogen demand (Fig. 3B).

CAM and $\mathrm{C}_{4}$ are $\mathrm{CO}_{2}$ concentrating mechanisms $(\mathrm{CCM})$ acquired by algae for carbon fixation to cope with high $\mathrm{O}_{2}$ concentrations relative to $\mathrm{CO}_{2}$ (Giordano et al. 2005; Reinfelder et al. 2000). Phosphoenolpyruvate carboxylase (PEPC) catalyzes the first reaction in $\mathrm{CAM} / \mathrm{C}_{4}$ process, incorporating inorganic carbon to phosphoenolpyruvate (PEP) to form the four-carbon compound oxaloacetate, which is used to release $\mathrm{CO}_{2}$ for carbon fixation in downstream reactions (Hatch \& Slack 1968). Transcripts for PEPC were over-represented at stations 70 and 120, and were under-represented at station 20. As phytoplankton consume $\mathrm{CO}_{2}$ and produce $\mathrm{O}_{2}$, the high biomass at stations 70 and 120 further increases the $\mathrm{O}_{2} / \mathrm{CO}_{2}$ ratio, which could explain the high expression of PEPC. Malate dehydrogenase (oxaloacetate-decarboxylating) catalyzes the release of $\mathrm{CO}_{2}$ so that $\mathrm{CO}_{2}$ can be utilized in the Calvin cycle. Malate dehydrogenases (oxaloacetate-decarboxylating) (K00025, K00026, K00029) were over-represented at station 20, indicative of high $\mathrm{CO}_{2}$ assimilation in the upper estuary phytoplankton community, consistent with high carbon fixation and high growth rates.

Energy production, carbon fixation and other growth metabolisms that were highly expressed at upper estuary were represented by WGCNA subnetworks MEmagenta and MEgreenyellow (Fig. 4C, Table. 3). These subnetworks had strong positive correlations with nitrogen concentrations $\left(\mathrm{NO}_{3}{ }^{-}, \mathrm{NH}_{4}{ }^{+}\right)$, thus growth metabolisms in general were positively 
related to nitrogen concentrations. Correlations between each individual module involved in growth metabolisms (including PSI, PSII, carbohydrate metabolism, ATP synthesis and ribosome metabolisms) and nitrogen concentrations were found to be strongly positive (Fig. 5A). Such positive correlations indicate nitrogen is essential for phytoplankton growth and suggests the high nitrogen concentrations explain why growth-related modules were highly expressed in the upper estuary.

In contrast, nitrogen-related processes (i.e., $\mathrm{NO}_{3}{ }^{-}$assimilation, urea transport system, $\mathrm{NO}_{3}{ }^{-}$reduction) were enriched in subnetwork MEred (Fig. 4C) and found to be negatively correlated with nitrogen concentration (i.e., $\mathrm{NO}_{3}{ }^{-}, \mathrm{NH}_{4}{ }^{+}$) (Fig. 5A). The negative correlation between these subnetworks and nitrogen concentrations is consistent with previous findings that have shown genes for nitrogen metabolism increase in expression when nitrogen is limiting (Maheswari et al. 2010; Kang et al. 2007; Song \& Ward 2007). Similarly, transporters for iron, multiple sugars, proline, phosphate, glycose were also negatively correlated with nitrogen concentrations, indicating there were high demands for those essential metabolites in the lower estuary. Co-expression patterns were detected among nitrogen utilization pathways, which indicates nitrogen-related metabolic functions were coordinated under nitrogen stress conditions. Other than nitrogen metabolism, transcription/translation activities (replication system, repair system, DNA polymerase) and ABC transport systems were also enriched in subnetworks (MEturquiose, MEblack) that were negatively correlated with nitrogen concentrations. Enrichment of transcription/translation activities can be another signal that phytoplankton were under nutrient stress as these processes have been shown to function as recycling mechanisms for protein and amino acids under nutrient stress (Liu et al., 2015). The ABC transport system is comprised of transmembrane transporters and are essential for saccharides export (Jones and 
George, 2004; Delbarre-Ladrat et al., 2014). Phytoplankton have been shown to export carbohydrate for multiple reasons, including balancing inner $\mathrm{C} / \mathrm{N}$ ratios and in exchange for remineralized nutrients from bacteria (Wear et al., 2015; Croft et al., 2005; Rinta-Kanto et al., 2012; Cooper and Smith, 2015; Azam et al., 1983; Gong et al., 2016). As illustrated above, phytoplankton have high demands for N, P and Fe in the lower estuary, thus elevated export of carbohydrate can be a key process to sustain surrounding bacteria growth for remineralized ammonium and enhancement of Fe availability (Seymour et al., 2017). Thus, enrichment of glycan metabolism, lipopolysaccharide metabolism and $\mathrm{ABC}$ transport system and the strong negative correlation between sugar transportation (multiple sugar transporter, $\mathrm{ABC}$ transport system) could infer there are mutualistic nutrients/carbon exchange mechanisms between phytoplankton and bacteria in the lower estuary. In addition, considering a limited $\mathrm{N}$ supply along with replete carbon sources, it is also reasonable for phytoplankton to export excess carbon-rich substrates to balance $\mathrm{C} / \mathrm{N}$ ratio.

\section{Summary}

Through combining gene expression profiling with measurements of environmental conditions and other water quality parameters, we have constructed a more comprehensive network analysis for the plankton community in the NRE. Phytoplankton implement different metabolic strategies in the upper and lower estuary as a consequence of the steep environmental gradients that persist in the NRE. In the upper estuary, where nutrients are replete, phytoplankton highly expressed photosynthesis, carbon fixation, and other growth-related metabolic pathways. While in the lower estuary, where nutrients are limiting, phytoplankton increase nutrient acquisition processes to scavenge the scarce nutrients from the environment and elevate their 
internal nutrient cycling to meet the high demands for various nutrients. Metabolisms for polysaccharide synthesis and transportation were elevated in lower estuary and could be reflective of unbalanced growth and/or interactions with their surrounding microbial consortia. Nitrogen concentrations are shown to be the main drivers for the divergence in the phytoplankton differences in gene expression between the upper and lower estuaries. Although $\mathrm{NO}_{3}{ }^{-}$ concentrations were found to be mostly limiting at Station 70, occasionally, high discharge events can deliver large amount of $\mathrm{NO}_{3}{ }^{-}$to station 70 resulting in blooms that may alter gene expression patterns to be more reflective of the upper estuary phytoplankton community. Sampling of such instances would enable a better understanding of the phytoplankton dynamics in the NRE.

The sensitivity of phytoplankton metabolic functional responses to their environment as elucidated through molecular approaches has provided us with a new tool for water quality monitoring within our valuable coastal regions. With the development of sequencing technology and corresponding bioinformatics tools, more informative models can be developed to better predict the consequences of changes in environmental factors on phytoplankton dynamics and the marine ecosystem. 
APPENDIX 1: SRA ACCESSION NUMBERS FOR METATRANSCRIPTOMIC SAMPLES

\begin{tabular}{cc}
\hline Sample & Study accession no. \\
\hline Sample_1_020 & SRR3218234 \\
Sample_1_070 & SRR3218378 \\
Sample_1_120 & SRR3219836 \\
Sample_1_180 & SRR3221672 \\
Sample_2_020 & SRR3233860 \\
Sample_2_070 & SRR3233861 \\
Sample_2_120 & SRR3233862 \\
Sample_2_180 & SRR3233863 \\
Sample_3_020 & SRR3233866 \\
Sample_3_070 & SRR3233867 \\
Sample_3_120 & SRR3233868 \\
Sample_3_180 & SRR3233869 \\
Sample_4_020 & SRR3233870 \\
Sample_4_070 & SRR3233886 \\
Sample_4_120 & SRR3233887 \\
Sample_4_180 & SRR3233926 \\
Sample_6_020 & SRR3234059 \\
Sample_6_070 & SRR3234060 \\
Sample_6_120 & SRR3234061 \\
Sample_6_180 & SRR3234482 \\
\hline &
\end{tabular}


APPENDIX 2: CUSTOM TAXONOMIC LOOK-UP TABLE

\begin{tabular}{|c|c|}
\hline Class & Custom Name \\
\hline Coscinodiscophyceae & Diatoms \\
\hline Chrysophyceae & Chrysophyte \\
\hline Dinophyceae & Dinoflagellates \\
\hline Spirotrichea & Ciliates \\
\hline Synurophyceae & Synurophytes \\
\hline Cryptophyta & Cryptophytes \\
\hline Prymnesiaceae & Haptophytes \\
\hline Fragilariophyceae & Diatoms \\
\hline Mamiellophyceae & Prasinophytes \\
\hline Chlorophyta & Chlorophycean \\
\hline Mediophyceae & Diatoms \\
\hline Litostomatea & Ciliates \\
\hline Dictyochophyceae & Dictyochophytes \\
\hline Chlorophyceae & Chlorophycean \\
\hline Foraminifera & Foramnifera \\
\hline Bacillariophyceae & Diatoms \\
\hline Oligohymenophorea & Ciliates \\
\hline Heterotrichea & Ciliates \\
\hline Trebouxiophyceae & Trebouxiophytes \\
\hline Phaeocystaceae & Haptophytes \\
\hline Raphidophyceae & Raphidophytes \\
\hline Pelagophyceae & Pelagophytes \\
\hline Prostomatea & Ciliates \\
\hline Thraustochytriaceae & Labyrinthulids \\
\hline Coccolithaceae & Haptophytes \\
\hline Colpodea & Ciliates \\
\hline Glaucocystophyceae & Glaucophytes \\
\hline Noelaerhabdaceae & Haptophytes \\
\hline Chromerida & Chromera \\
\hline Chlorodendrophyceae & Chlorophycean \\
\hline Codonosigidae & Choanoflagellates \\
\hline Pavlovaceae & Haptophytes \\
\hline \multicolumn{2}{|l|}{ Alphaproteobacteria } \\
\hline Acanthoecidae & Choanoflagellates \\
\hline Isochrysidaceae & Haptophytes \\
\hline Bangiophyceae & Bangiophytes \\
\hline Xanthophyceae & Xanthophytes \\
\hline \multicolumn{2}{|l|}{ Synchromophyceae } \\
\hline Flavobacteriia & \\
\hline Bolidophyceae & Bolidophytes \\
\hline
\end{tabular}




\begin{tabular}{cc}
\hline Agaricomycetes & Basidiomycetes \\
Gammaproteobacteria & \\
Chrysochromulinaceae & Haptophytes \\
Compsopogonophyceae & \\
Paramoebidae & Dactyiopodids \\
Verrucomicrobia & \\
Cyanobacteria & \\
Cafeteriaceae & Bicosoecids \\
Nephroselmidophyceae & Prasinophytes \\
Euglenida & Euglenids \\
Pleurochrysidaceae & Haptophytes \\
Vannellidae & Vannellids \\
Betaproteobacteria & \\
Echinamoebidae & Tubulinids \\
Streptophyta & \\
Calcidiscaceae & Haptophytes \\
Eustigmatophyceae & Eustigmatophytes \\
Heterolobosea & Heteroloboseans \\
Pinguiophyceae & Pinguiophytes \\
Rhodellophyceae & \\
Stylonematophyceae & \\
Planctomycetia & \\
Vexilliferidae & Dactyiopodids \\
Euryarchaeota & \\
Sphingobacteriia & \\
Perkinsidae & Perkinsus \\
Saccharomycetes & Ascomycetes \\
Thaumarchaeota & \\
Actinobacteria & \\
Cytophagia & Tubulinids \\
Difflugiidae & Euglenids \\
Bodonidae & Apicomplexa \\
Gregarinasina & Haplosporidia \\
Haplosporidia & \\
Lentisphaeria & \\
Thermoplasmata & \\
Marinimicrobia & \\
& \\
\hline & \\
& \\
& \\
& \\
&
\end{tabular}




\section{APPENDIX 3: RESULT OF DIFFERENTIAL EXPRESSION ANALYSIS}

\begin{tabular}{|c|c|c|c|c|c|c|c|}
\hline module & upper & lower & $\log \mathrm{FC}$ & $\log \mathrm{CPM}$ & name & clas3 & pvalue \\
\hline M00001 & 281726 & 97625 & -1.529 & 17.5332 & $\begin{array}{l}\text { Glycolysis (Embden-Meyerhof } \\
\text { pathway), glucose }=>\text { pyruvate }\end{array}$ & $\begin{array}{l}\text { Central carbohydrate } \\
\text { metabolism }\end{array}$ & $3.62 \mathrm{E}-07$ \\
\hline M00002 & 206705 & 73424.6 & -1.4932 & 17.0957 & $\begin{array}{l}\text { Glycolysis, core module involving } \\
\text { three-carbon compounds }\end{array}$ & $\begin{array}{l}\text { Central carbohydrate } \\
\text { metabolism }\end{array}$ & $1.70 \mathrm{E}-07$ \\
\hline M00003 & 286768 & 97031.2 & -1.5634 & 17.55 & $\begin{array}{l}\text { Gluconeogenesis, oxaloacetate }=> \\
\text { fructose-6P }\end{array}$ & $\begin{array}{l}\text { Central carbohydrate } \\
\text { metabolism }\end{array}$ & $5.33 \mathrm{E}-12$ \\
\hline M00004 & 39678.3 & 15250.7 & -1.3795 & 14.7453 & $\begin{array}{l}\text { Pentose phosphate pathway (Pentose } \\
\text { phosphate cycle) }\end{array}$ & $\begin{array}{l}\text { Central carbohydrate } \\
\text { metabolism } \\
\text { Central carbohydrate }\end{array}$ & $8.99 \mathrm{E}-10$ \\
\hline M00005 & 134.274 & 141.189 & 0.07244 & 7.10571 & PRPP biosynthesis, ribose 5P $\Rightarrow$ PRPP & metabolism & 0.90272 \\
\hline M00006 & 892.197 & 2056.69 & 1.20489 & 10.526 & $\begin{array}{l}\text { Pentose phosphate pathway, oxidative } \\
\text { phase, glucose } 6 \mathrm{P}=>\text { ribulose } 5 \mathrm{P}\end{array}$ & $\begin{array}{l}\text { Central carbohydrate } \\
\text { metabolism }\end{array}$ & 0.0128 \\
\hline M00007 & 37115.7 & 12332.5 & -1.5896 & 14.5936 & $\begin{array}{l}\text { Pentose phosphate pathway, non- } \\
\text { oxidative phase, fructose } 6 \mathrm{P}=>\text { ribose } \\
5 \mathrm{P}\end{array}$ & $\begin{array}{l}\text { Central carbohydrate } \\
\text { metabolism }\end{array}$ & $1.79 \mathrm{E}-09$ \\
\hline M00008 & 470.645 & 924.86 & 0.9746 & 9.44657 & $\begin{array}{l}\text { Entner-Doudoroff pathway, glucose- } 6 \mathrm{P} \\
=>\text { glyceraldehyde- } 3 \mathrm{P}+\text { pyruvate }\end{array}$ & $\begin{array}{l}\text { Central carbohydrate } \\
\text { metabolism } \\
\text { Central carbohydrate }\end{array}$ & 0.32818 \\
\hline M00009 & 33637.6 & 22990.8 & -0.549 & 14.7892 & Citrate cycle (TCA cycle, Krebs cycle) & metabolism & 0.05221 \\
\hline M00010 & 10596.2 & 7375.16 & -0.5228 & 13.1334 & $\begin{array}{l}\text { Citrate cycle, first carbon oxidation, } \\
\text { oxaloacetate }=>2 \text {-oxoglutarate } \\
\text { Citrate cycle, second carbon oxidation, }\end{array}$ & $\begin{array}{l}\text { Irbohydrate } \\
\text { m } \\
\text { Irbohydrate }\end{array}$ & 0.1814 \\
\hline M00011 & 23041.4 & 15615.6 & -0.5612 & 14.2384 & 2-oxoglutarate $=>$ oxaloacetate & $\begin{array}{l}\text { metabolism } \\
\text { Other carbohydrate }\end{array}$ & 0.089 \\
\hline M00012 & 19558.3 & 9361.02 & -1.063 & 13.8197 & Glyoxylate cycle & metabolism & 0.00128 \\
\hline M00013 & 1028.65 & 898.32 & -0.1955 & 9.91212 & $\begin{array}{l}\text { Malonate semialdehyde pathway, } \\
\text { propanoyl-CoA }=>\text { acetyl-CoA }\end{array}$ & $\begin{array}{l}\text { Other carbohydrate } \\
\text { metabolism } \\
\text { Other carbohydrate }\end{array}$ & 0.99542 \\
\hline M00014 & 4899.16 & 2195.42 & -1.158 & 11.7925 & Glucuronate pathway (uronate pathway) & nd proline & 0.02543 \\
\hline M00015 & 159.569 & 246.629 & 0.62816 & 7.66604 & $\begin{array}{l}\text { proline } \\
\text { Lysine biosynthesis, succinyl-DAP }\end{array}$ & $\begin{array}{l}\text { Arginine and } \\
\text { metabolism }\end{array}$ & 0.10156 \\
\hline M00016 & 4252.05 & 2001.6 & -1.087 & 11.6105 & pathway, as & $\begin{array}{l}\text { Lysine metabolism } \\
\text { Cysteine and }\end{array}$ & 0.08863 \\
\hline M00017 & 3329.21 & 1821.4 & -0.8701 & 11.3305 & $\begin{array}{l}\text { Methionine biosynthesis, apartate }=> \\
\text { homoserine }=>\text { methionine } \\
\text { Threonine biosynthesis, aspartate }=>\end{array}$ & metabolism & 0.01929 \\
\hline M00018 & 3238.12 & 1449.9 & -1.1592 & 11.1948 & $\begin{array}{l}\text { homoserine }=>\text { threonine } \\
\text { Valine/isoleucine biosynthesis, pyruvate }\end{array}$ & metabolism & 0.02442 \\
\hline M00019 & 4936.64 & 2167.52 & -1.1875 & 11.7944 & $\begin{array}{l}\Rightarrow>\text { valine / } 2 \text {-oxobutanoate }=> \\
\text { isoleucine } \\
\text { Serine biosynthesis olvcerate-3P }=>\end{array}$ & $\begin{array}{l}\text { Branched-chain amino } \\
\text { acid metabolism }\end{array}$ & 0.25961 \\
\hline M00020 & 1161.86 & 1477.15 & 0.34638 & 10.3658 & iesis, glycerate-3P => & $\begin{array}{l}\text { metabolism } \\
\text { Cysteine and }\end{array}$ & 0.56789 \\
\hline M00021 & 409.583 & 372.567 & -0.1367 & 8.6113 & $\begin{array}{l}\text { Cysteine biosynthesis, serine }=> \\
\text { cysteine } \\
\text { Shikimate pathway, }\end{array}$ & $\begin{array}{l}\text { methionine } \\
\text { metabolism }\end{array}$ & 0.05428 \\
\hline M00022 & 988.933 & 680.255 & -0.5398 & 9.70493 & $\begin{array}{l}\text { phosphoenolpyruvate }+ \text { erythrose- } 4 \mathrm{P}=> \\
\text { chorismate } \\
\text { Tryptophan biosynthesis, chorismate }=>\end{array}$ & $\begin{array}{l}\text { Aromatic amino acid } \\
\text { metabolism } \\
\text { Aromatic amino acid }\end{array}$ & 0.22741 \\
\hline M00023 & 582.168 & 513.104 & -0.1822 & 9.09707 & $\begin{array}{l}\text { tryptophan } \\
\text { Phenylalanine biosynthesis, chorismate }\end{array}$ & $\begin{array}{l}\text { metabolism } \\
\text { Aromatic amino acid }\end{array}$ & 0.48835 \\
\hline M00024 & 87.3266 & 64.2596 & -0.4425 & 6.244 & $\begin{array}{l}\Rightarrow>\text { phenylalanine } \\
\text { Tyrosine biosynthesis, chorismate }=>\end{array}$ & $\begin{array}{l}\text { metabolism } \\
\text { Aromatic amino acid }\end{array}$ & 0.96544 \\
\hline M00025 & 121.807 & 146.253 & 0.26387 & 7.06641 & $\begin{array}{l}\text { tyrosine } \\
\text { Histidine biosynthesis, PRPP }=>\end{array}$ & metabolism & 0.9663 \\
\hline M00026 & 267.196 & 270.587 & 0.0182 & 8.07088 & histidine & $\begin{array}{l}\text { Histidine metabolism } \\
\text { Other amino acid }\end{array}$ & 0.91699 \\
\hline M00027 & 152.042 & 362.426 & 1.25321 & 8.00694 & $\begin{array}{l}\text { GABA (gamma-Aminobutyrate) shunt } \\
\text { Ornithine biosynthesis, glutamate }=>\end{array}$ & $\begin{array}{l}\text { metabolism } \\
\text { Arginine and proline }\end{array}$ & 0.62037 \\
\hline M00028 & 232.134 & 199.519 & -0.2184 & 7.75373 & & $\begin{array}{l}\text { metabolism } \\
\text { Arginine and proline }\end{array}$ & 0.50052 \\
\hline M00029 & 755.91 & 699.246 & -0.1124 & 9.50696 & Urea cycle & metabolism & 0.52802 \\
\hline
\end{tabular}




\begin{tabular}{|c|c|c|c|c|c|c|c|}
\hline M00030 & 365.215 & 239.643 & -0.6079 & 8.24045 & $\begin{array}{l}\text { oxoglutarate => 2-aminoadipate }=> \\
\text { lysine }\end{array}$ & Lysine metabolism & 0.99906 \\
\hline M00031 & 1.31453 & 0.86361 & -0.6061 & 0.1231 & $\begin{array}{l}\text { Lysine biosynthesis, mediated by LysW, } \\
\text { 2-aminoadipate }=>\text { lysine } \\
\text { Lysine degradation, lysine } \Rightarrow>\end{array}$ & Lysine metabolism & 0.77096 \\
\hline M00032 & 3110.92 & 2209.58 & -0.4936 & 11.3773 & saccharopine $=>$ acetoacetyl-CoA & Lysine metabolism & 0.79761 \\
\hline M00033 & 2475.94 & 588.285 & -2.0734 & 10.5813 & $\begin{array}{l}\text { Ectoine biosynthesis, aspartate }=> \\
\text { ectoine }\end{array}$ & $\begin{array}{l}\text { Other amino acid } \\
\text { metabolism }\end{array}$ & $3.03 \mathrm{E}-05$ \\
\hline M00034 & 22831.9 & 14306.3 & -0.6744 & 14.1806 & Methionine salvage pathway & $\begin{array}{l}\text { Cysteine and } \\
\text { methionine } \\
\text { metabolism } \\
\text { Cysteine and } \\
\text { methionine }\end{array}$ & 0.31296 \\
\hline M00035 & 26935.1 & 18198.5 & -0.5657 & 14.4619 & Methionine degradation & metabolism & 0.18287 \\
\hline M00036 & 5343.58 & 4496.34 & -0.2491 & 12.2644 & $\begin{array}{l}\text { Leucine degradation, leucine }=> \\
\text { acetoacetate }+ \text { acetyl-CoA } \\
\text { Melatonin biosynthesis, tryptophan }=>\end{array}$ & $\begin{array}{l}\text { Branched-chain amino } \\
\text { acid metabolism } \\
\text { Aromatic amino acid }\end{array}$ & 0.9907 \\
\hline M00037 & 10.164 & 8.94916 & -0.1836 & 3.2565 & $\begin{array}{l}\text { Melatonin biosynthesis, tryptophan }=> \\
\text { serotonin => melatonin } \\
\text { Tryptophan metabolism, tryptophan }=>\end{array}$ & $\begin{array}{l}\text { Aromatic amino acid } \\
\text { metabolism } \\
\text { Aromatic amino acid }\end{array}$ & 0.92635 \\
\hline M00038 & 76.7321 & 168.456 & 1.13447 & 6.93775 & $\begin{array}{l}\text { kynurenine }=>2 \text {-aminomuconate } \\
\text { Monolignol biosynthesis }\end{array}$ & $\begin{array}{l}\text { metabolism } \\
\text { Biosynthesis of }\end{array}$ & 0.8509 \\
\hline M00039 & 70.0214 & 289.619 & 2.04829 & 7.49041 & $\begin{array}{l}\text { phenylalanine/tyrosine }=>\text { monolignol } \\
\text { Tyrosine biosynthesis, prephanate }=>\end{array}$ & $\begin{array}{l}\text { secondary metabolites } \\
\text { Aromatic amino acid }\end{array}$ & 0.0537 \\
\hline M00040 & 48.4494 & 61.6981 & 0.34875 & 5.78329 & $\begin{array}{l}\text { pretyrosine }=>\text { tyrosine } \\
\text { Catecholamine biosynthesis, tyrosine }=>\end{array}$ & metabolism & 0.13069 \\
\hline M00042 & 156.658 & 278.496 & 0.83003 & 7.76538 & $\begin{array}{l}\text { dopamine }=>\text { noradrenaline }=> \\
\text { adrenaline } \\
\text { Tyrosine degradation, tyrosine }=>\end{array}$ & $\begin{array}{l}\text { Aromatic amino acid } \\
\text { metabolism } \\
\text { Aromatic amino acid }\end{array}$ & 0.47539 \\
\hline M00044 & 217.902 & 256.272 & 0.234 & 7.88927 & $\begin{array}{l}\text { homogentisate } \\
\text { Histidine degradation, histidine }=>\mathrm{N} \text { - }\end{array}$ & metabol & 0.74639 \\
\hline M00045 & 12.0302 & 27.8771 & 1.21242 & 4.31858 & $\begin{array}{l}\text { formiminoglutamate }=>\text { glutamate } \\
\text { Pyrimidine degradation, uracil }=>\text { beta- }\end{array}$ & Histidine metabolism & 0.39537 \\
\hline M00046 & 148.663 & 101.816 & -0.5461 & 6.96854 & $\begin{array}{l}\text { alanine, thymine }=>3- \\
\text { aminoisobutanoate }\end{array}$ & $\begin{array}{l}\text { Pyrimidine } \\
\text { metabolism } \\
\text { Other amino acid }\end{array}$ & 0.6943 \\
\hline M00047 & 1096.48 & 1012.41 & -0.1151 & 10.0423 & $\begin{array}{l}\text { Creatine pathway } \\
\text { Inosine monophosphate biosynthesis, }\end{array}$ & metabolism & 0.45958 \\
\hline M00048 & 659.764 & 1037.91 & 0.65366 & 9.72934 & $\begin{array}{l}\text { PRPP }+ \text { glutamine }=>\text { IMP } \\
\text { Adenine ribonucleotide biosynthesis, }\end{array}$ & Purine metabolism & 0.6699 \\
\hline M00049 & 14468.1 & 6408.82 & -1.1747 & 13.3496 & $\begin{array}{l}\mathrm{IMP}=>\text { ADP,ATP } \\
\text { Guanine ribonucleotide biosynthesis }\end{array}$ & Purine metabolism & 0.11932 \\
\hline M00050 & 13405.1 & 5871.7 & -1.1909 & 13.2346 & $\begin{array}{l}\text { IMP => GDP,GTP } \\
\text { Uridine monophosphate biosynthesis, }\end{array}$ & $\begin{array}{l}\text { Purine metabolism } \\
\text { Pyrimidine }\end{array}$ & 0.13419 \\
\hline M00051 & 234.821 & 518.962 & 1.14407 & 8.55801 & $\begin{array}{l}\text { glutamine }(+ \text { PRPP })=>\text { UMP } \\
\text { Pyrimidine ribonucleotide biosynthesis, }\end{array}$ & $\begin{array}{l}\text { metabolism } \\
\text { Pyrimidine }\end{array}$ & 0.34649 \\
\hline M00052 & 9644.88 & 2713.23 & -1.8298 & 12.5932 & $\begin{array}{l}\mathrm{UMP}=>\text { UDP/UTP,CDP/CTP } \\
\text { Pyrimidine deoxyribonuleotide }\end{array}$ & metabolism & 0.01041 \\
\hline M00053 & 10794.6 & 5465.91 & -0.9818 & 12.9891 & $\begin{array}{l}\text { biosynthesis, CDP/CTP }=> \\
\text { dCDP/dCTP,dTDP/dTTP }\end{array}$ & $\begin{array}{l}\text { Pyrimidine } \\
\text { metabolism }\end{array}$ & 0.00126 \\
\hline M00055 & 94.3028 & 150.27 & 0.67219 & 6.93412 & $\mathrm{~N}$-glycan precursor biosynthesis & Glycan metabolism & 0.29252 \\
\hline M00056 & 30.8445 & 84.2602 & 1.44984 & 5.8468 & $\begin{array}{l}\text { O-glycan biosynthesis, mucin type core } \\
\text { Glycosaminoglycan biosynthesis, }\end{array}$ & $\begin{array}{l}\text { Glycan metabolism } \\
\text { Glycosaminoglycan }\end{array}$ & 0.22431 \\
\hline M00057 & 9.51106 & 15.9151 & 0.74272 & 3.66824 & $\begin{array}{l}\text { linkage tetrasaccharide } \\
\text { Glycosaminoglycan biosynthesis, }\end{array}$ & & 0.62346 \\
\hline M00058 & 0.46228 & 6.59144 & 3.83377 & 1.81838 & $\begin{array}{l}\text { chondroitin sulfate backbone } \\
\text { Glycosaminoglycan biosynthesis, }\end{array}$ & & 0.4496 \\
\hline M00059 & 48.0671 & 34.5697 & -0.4755 & 5.36871 & & $\begin{array}{l}\text { metabolism } \\
\text { Lipopolysaccharide }\end{array}$ & 0.93744 \\
\hline M00060 & 26.4393 & 42.286 & 0.6775 & 5.10277 & $\begin{array}{l}\text { KDO2-lipid A } \\
\text { D-Glucuronate degradation, D- } \\
\text { glucuronate }=>\text { pyruvate }+ \text { D- }\end{array}$ & metabolism & 0.75181 \\
\hline M00061 & 9.16631 & 134.244 & 3.87237 & 6.164 & & & 0.16524 \\
\hline M00063 & 30.2795 & 219.363 & 2.85691 & 6.96372 & $\begin{array}{l}\text { CMP-KDO biosynthesis } \\
\text { ADP-L-glycero-D-manno-heptose }\end{array}$ & & 0.01951 \\
\hline M00064 & 2.50053 & 3.97471 & 0.66862 & 1.69493 & $\begin{array}{l}\text { biosynthesis } \\
\text { GPI-anchor biosynthesis, core }\end{array}$ & metabolism & 0.61363 \\
\hline M00065 & 176.936 & 149.965 & -0.2386 & 7.35271 & oligosaccharide & Glycan metabolism & 0.21127 \\
\hline
\end{tabular}




\begin{tabular}{|c|c|c|c|c|c|c|c|}
\hline M00066 & 0.3584 & 0.64491 & 0.84751 & -0.9952 & Lactosylceramide biosynthesis & Lipid metabolism & 0.98543 \\
\hline M00067 & 0.11285 & 18.6554 & 7.36898 & 3.23022 & $\begin{array}{l}\text { Sulfoglycolipids biosynthesis, } \\
\text { ceramide/1-alkyl-2-acylglycerol => } \\
\text { sulfatide/seminolipid } \\
\text { Glycosphingolipid biosynthesis, globo- }\end{array}$ & Lipid metabolism & 0.53011 \\
\hline M00068 & 2.5459 & 1.34624 & -0.9192 & 0.96057 & $\begin{array}{l}\text { series, LacCer }=>\text { Gb4Cer } \\
\text { Glycosphingolinid biosynthesis, ganglio }\end{array}$ & Glycan metabolism & 0.60911 \\
\hline M00069 & 0.04356 & 0.80911 & 4.21528 & -1.2299 & & Glycan metabolism & 0.81109 \\
\hline M00070 & 0.39173 & 3.61043 & 3.20424 & 1.00078 & $\begin{array}{l}\text { series, LacCer }=>\text { Lc4Cer } \\
\text { Glycosphingolipid biosynthesis, }\end{array}$ & Glycan metabolism & 0.99383 \\
\hline M00071 & 0.7778 & 4.46949 & 2.52264 & 1.39157 & $\begin{array}{l}\text { neolacto-series, } \mathrm{LacCer}=>\text { nLc } 4 \text { Cer } \\
\text { N-glycosylation by }\end{array}$ & Glycan metabolism & 0.9922 \\
\hline M00072 & 667.012 & 506.07 & -0.3984 & 9.19609 & oligosaccharyltransferase & Glycan metabolism & 0.09578 \\
\hline M00073 & 283.296 & 322.841 & 0.18851 & 8.2435 & $\begin{array}{l}\mathrm{N} \text {-glycan precursor trimming } \\
\mathrm{N} \text {-glycan biosynthesis, high-mannose }\end{array}$ & Glycan metabolism & 0.92991 \\
\hline M00074 & 275.677 & 324.605 & 0.23571 & 8.2295 & type & Glycan metabolism & 0.90589 \\
\hline M00075 & 9.20599 & 69.515 & 2.91668 & 5.29868 & $\mathrm{~N}$-glycan biosynthesis, complex type & $\begin{array}{l}\text { Glycan metabolism } \\
\text { Glycosaminoglycan }\end{array}$ & 0.39687 \\
\hline M00076 & 15.727 & 77.7502 & 2.3056 & 5.54654 & Dermatan sulfate degradation & $\begin{array}{l}\text { metabolism } \\
\text { Glycosaminoglycan }\end{array}$ & 0.95419 \\
\hline M00077 & 10.1579 & 56.0668 & 2.46454 & 5.0493 & Chondroitin sulfate degradation & $\begin{array}{l}\text { metabolism } \\
\text { Glycosaminoglycan }\end{array}$ & 0.87684 \\
\hline M00078 & 16.6455 & 71.0124 & 2.09294 & 5.45381 & Heparan sulfate degradation & $\begin{array}{l}\text { metabolism } \\
\text { Glycosaminoglycan }\end{array}$ & 0.91866 \\
\hline M00079 & 60.6782 & 245.233 & 2.0149 & 7.25697 & $\begin{array}{l}\text { Keratan sulfate degradation } \\
\text { Lipopolysaccharide biosynthesis, inner }\end{array}$ & $\begin{array}{l}\text { metabolism } \\
\text { Lipopolysaccharide }\end{array}$ & 0.08219 \\
\hline M00080 & 0.30048 & 6.12494 & 4.34937 & 1.68379 & core $=>$ outer core $=>$ O-antigen & $\begin{array}{l}\text { metabolism } \\
\text { Other carbohydrate }\end{array}$ & 0.96939 \\
\hline M00081 & 0.09137 & 9.18182 & 6.65097 & 2.21306 & Pectin degradation & metabolism & 0.40528 \\
\hline M00082 & 2277.2 & 1804.08 & -0.336 & 10.9948 & Fatty acid biosynthesis, initiation & Fatty acid metabolism & 0.00043 \\
\hline M00083 & 3659.89 & 1629.34 & -1.1675 & 11.3688 & Fatty acid biosynthesis, elongation & Fatty acid metabolism & 0.00508 \\
\hline M00085 & 1486.3 & 833.557 & -0.8344 & 10.1798 & $\begin{array}{l}\text { mitochondria } \\
\text { mesis, elongation, }\end{array}$ & Fatty acid metabolism & 0.07184 \\
\hline M00086 & 830.924 & 1508.93 & 0.86074 & 10.1922 & beta-Oxidation, acyl-CoA synthesis & Fatty acid metabolism & 0.14672 \\
\hline M00087 & 2401.47 & 2197.97 & -0.1277 & 11.1672 & $\begin{array}{l}\text { beta-Oxidation } \\
\text { Ketone body biosynthesis, acetyl-CoA } \\
=>\text { acetoacetate/3- }\end{array}$ & Fatty acid metabolism & 0.49673 \\
\hline M00088 & 938.679 & 459.859 & -1.0294 & 9.4497 & hydroxybutyrate/acetone & Fatty acid metabolism & 0.05375 \\
\hline M00089 & 384.327 & 445.512 & 0.21313 & 8.69669 & Triacylglycerol biosynthesis & Lipid metabolism & 0.93683 \\
\hline M00090 & 28.9987 & 78.0768 & 1.4289 & 5.74248 & $\begin{array}{l}\text { choline } \Rightarrow P C \\
\text { Phosphatidylcholine (PC) biosynthesis, }\end{array}$ & Lipid metabolism & 0.08878 \\
\hline M00091 & 49.7442 & 2.50942 & -4.3091 & 4.70746 & & Lipid metabolism & 0.14372 \\
\hline M00092 & 72.1649 & 136.065 & 0.91492 & 6.70203 & & Lipid metabolism & 0.02927 \\
\hline M00093 & 79.8099 & 143.917 & 0.85059 & 6.80559 & & Lipid metabolism & 0.34468 \\
\hline M00094 & 433.613 & 740.431 & 0.77196 & 9.19727 & esis & & 0.15977 \\
\hline M00095 & 1251.72 & 806.002 & -0.6351 & 10.0068 & $\begin{array}{l}\text { pathway } \\
\text { C5 isoprenoid biosynthesis, non- }\end{array}$ & $\begin{array}{l}\text { biosynthesis } \\
\text { Terpenoid backbone }\end{array}$ & 0.50284 \\
\hline M00096 & 1252.04 & 1066.23 & -0.2318 & 10.1788 & & $\begin{array}{l}\text { biosynthesis } \\
\text { Other terpenoid }\end{array}$ & 0.68373 \\
\hline M00097 & 266.322 & 244.519 & -0.1232 & 7.99673 & beta-carotene & biosynthesis & 0.85481 \\
\hline M00098 & 148.891 & 172.495 & 0.2123 & 7.32816 & Acylglycerol degradation & Lipid metabolism & 0.99761 \\
\hline M00099 & 489.995 & 785.685 & 0.68118 & 9.31705 & Sphingosine biosynthesis & Lipid metabolism & 0.33092 \\
\hline M00100 & 23.2893 & 122.056 & 2.3898 & 6.18334 & $\begin{array}{l}\text { Sphingosine degradation } \\
\text { Cholesterol biosynthesis, squalene 2,3- }\end{array}$ & Lipid metabolism & 0.03583 \\
\hline M00101 & 838.337 & 594.871 & -0.495 & 9.48503 & epoxide $=>$ cholesterol & Sterol biosynthesis & 0.06065 \\
\hline M00102 & 714.443 & 596.695 & -0.2598 & 9.3566 & Ergocalciferol biosynthesis & Sterol biosynthesis & 0.25526 \\
\hline
\end{tabular}




\begin{tabular}{|c|c|c|c|c|c|c|c|}
\hline M00104 & 52.0391 & 231.738 & 2.15483 & 7.14862 & $\begin{array}{l}\text { Bile acid biosynthesis, cholesterol => } \\
\text { cholate/chenodeoxycholate } \\
\text { Conjugated bile acid biosvnthesis, }\end{array}$ & Sterol biosynthesis & 0.11966 \\
\hline M00106 & 1.35243 & 0.05004 & -4.7562 & -0.512 & $\begin{array}{l}\text { cholate => taurocholate/glycocholate } \\
\text { cholesid hormone biosynthesis, } \\
\text { cholel => prognenolone }=>\end{array}$ & Sterol biosynthesis & 0.04822 \\
\hline M00107 & 0.13723 & 2.32207 & 4.08071 & 0.29825 & $\begin{array}{l}\text { progesterone } \\
\text { C21-Steroid hormone biosynthesis, }\end{array}$ & Sterol biosynthesis & 0.86223 \\
\hline M00109 & 1.61582 & 4.42713 & 1.45411 & 1.59525 & $\begin{array}{l}\text { progesterone }=>\text { cortisol/cortisone } \\
\text { C } 19 / \mathrm{C} 18 \text {-Steroid hormone biosynthesis, } \\
\text { pregnenolone }=>\text { androstenedione }=>\end{array}$ & Sterol biosynthesis & 0.77727 \\
\hline M00110 & 0.1496 & 4.82393 & 5.01104 & 1.31427 & estrone & $\begin{array}{l}\text { Sterol biosynthesis } \\
\text { Cofactor and vitamin }\end{array}$ & 0.58149 \\
\hline M00112 & 97.8085 & 87.0043 & -0.1689 & 6.52992 & Tocopherol/tocotorienol biosynthesis & biosynthesis & 0.73767 \\
\hline M00113 & 631.54 & 996.866 & 0.65853 & 9.66924 & $\begin{array}{l}\text { Jasmonic acid biosynthesis } \\
\text { Ascorbate biosynthesis, plants, glucose- }\end{array}$ & $\begin{array}{l}\text { Fatty acid metabolism } \\
\text { Cofactor and vitamin }\end{array}$ & 0.54126 \\
\hline M00114 & 2481.93 & 1698.6 & -0.5471 & 11.0295 & $6 \mathrm{P} \Rightarrow>$ ascorbate & $\begin{array}{l}\text { biosynthesis } \\
\text { Cofactor and vitamin }\end{array}$ & 0.42405 \\
\hline M00115 & 166.645 & 183.249 & 0.13702 & 7.45077 & $\begin{array}{l}\text { NAD biosynthesis, aspartate }=>\text { NAD } \\
\text { Menaquinone biosynthesis, chorismate }\end{array}$ & $\begin{array}{l}\text { biosynthesis } \\
\text { Cofactor and vitamin }\end{array}$ & 0.63294 \\
\hline M00116 & 14.6583 & 32.5423 & 1.1506 & 4.56073 & $\begin{array}{l}\Rightarrow>\text { menaquinone } \\
\text { Ubiquinone biosynthesis, prokaryotes, }\end{array}$ & $\begin{array}{l}\text { biosynthesis } \\
\text { Cofactor and vitamin }\end{array}$ & 0.67325 \\
\hline M00117 & 17.8928 & 34.908 & 0.96418 & 4.72249 & $\begin{array}{l}\text { chorismate }=>\text { ubiquinone } \\
\text { Glutathione biosynthesis, glutamate } \Rightarrow>\end{array}$ & $\begin{array}{l}\text { biosynthesis } \\
\text { Cofactor and vitamin }\end{array}$ & 0.61788 \\
\hline M00118 & 167.63 & 192.946 & 0.20292 & 7.49416 & $\begin{array}{l}\text { glutathione } \\
\text { Pantothenate biosynthesis, valine/L- } \\
\text { aspartate => pantothenate }\end{array}$ & $\begin{array}{l}\text { biosynthesis } \\
\text { Cofactor and vitamin } \\
\text { biosynthesis }\end{array}$ & 0.96043 \\
\hline M00120 & 22.4923 & 45.9944 & 1.03203 & 5.09775 & $\begin{array}{l}\text { Coenzyme A biosynthesis, pantothenate } \\
=>\text { CoA } \\
\text { Heme biosynthesis, glutamate }=>\end{array}$ & $\begin{array}{l}\text { Cofactor and vitamin } \\
\text { biosynthesis } \\
\text { Cofactor and vitamin }\end{array}$ & 0.66998 \\
\hline M00121 & 5362.33 & 2154.68 & -1.3154 & 11.8759 & $\begin{array}{l}\text { protoheme } / \text { siroheme } \\
\text { Cobalamin biosynthesis, cobinamide } \Rightarrow>\end{array}$ & $\begin{array}{l}\text { biosynthesis } \\
\text { Cofactor and vitamin }\end{array}$ & 0.0121 \\
\hline M00122 & 6.3867 & 14.7948 & 1.21194 & 3.40473 & $\begin{array}{l}\text { cobalamin } \\
\text { Biotin biosynthesis, pimeloyl-ACP/CoA }\end{array}$ & $\begin{array}{l}\text { biosynthesis } \\
\text { Cofactor and vitamin }\end{array}$ & 0.76842 \\
\hline M00123 & 212.804 & 98.8885 & -1.1056 & 7.28398 & $\Rightarrow$ biotin & $\begin{array}{l}\text { biosynthesis } \\
\text { Cofactor and vitamin }\end{array}$ & 0.55826 \\
\hline M00124 & 791.537 & 1079.69 & 0.44789 & 9.86977 & $\begin{array}{l}\text { pyridoxal-5P } \\
\text { Riboflavin biosynthesis, GTP }=>\end{array}$ & $\begin{array}{l}\text { biosynthesis } \\
\text { Cofactor and vitamin }\end{array}$ & 0.60495 \\
\hline MOOILS & 192.158 & 304.559 & ค0?00? & 1.9551 & Tetrahydrofolate biosynthesis, GTP $\Rightarrow>$ & Cofactor and vitamin & $0.04 / 1 / 1$ \\
\hline M00126 & 145.134 & 592.826 & 2.03022 & 8.5274 & $\begin{array}{l}\text { THF } \\
\text { Thiamine biosynthesis, AIR }=>\end{array}$ & $\begin{array}{l}\text { biosynthesis } \\
\text { Cofactor and vitamin }\end{array}$ & 0.16327 \\
\hline M00127 & 54.8462 & 19.8691 & -1.4649 & 5.22333 & $\begin{array}{l}\text { thiamine-P/thiamine- } 2 \mathrm{P} \\
\text { Ubiquinone biosynthesis, eukaryotes, } 4 \text { - } \\
\text { hydroxybenzoate => ubiquinone }\end{array}$ & $\begin{array}{l}\text { biosynthesis } \\
\text { Cofactor and vitamin } \\
\text { biosynthesis }\end{array}$ & 0.1073 \\
\hline M00129 & 6112.69 & 2321.11 & -1.397 & 12.042 & $\begin{array}{l}\text { Ascorbate biosynthesis, animals, } \\
\text { glucose- } 1 \mathrm{P}=>\text { ascorbate } \\
\text { Inositol phosphate metabolism, } \mathrm{PI}=>\end{array}$ & $\begin{array}{l}\text { Cofactor and vitamin } \\
\text { biosynthesis }\end{array}$ & 0.00712 \\
\hline M00130 & 55.6352 & 278.551 & 2.32387 & 7.38451 & $\begin{array}{l}\mathrm{PIP} 2 \Rightarrow \operatorname{Ins}(1,4,5) \mathrm{P} 3 \Rightarrow \operatorname{Ins}(1,3,4,5) \mathrm{P} 4 \\
\text { Inositol phosphate metabolism, }\end{array}$ & Lipid metabolism & 0.00723 \\
\hline M00131 & 36.1291 & 89.9995 & 1.31676 & 5.97875 & $\begin{array}{l}\text { inositol } \\
\text { Inositol phosphate metabolism, }\end{array}$ & Lipid metabolism & 0.66641 \\
\hline M00132 & 6.561 & 52.3227 & 2.99545 & 4.8798 & $\begin{array}{l}\text { Ins }(1,3,4) \mathrm{P} 3=>\text { phytate } \\
\text { Polyamine biosynthesis, arginine }=>\end{array}$ & $\begin{array}{l}\text { Lipid metabolism } \\
\text { Polyamine }\end{array}$ & 0.32329 \\
\hline M00133 & 1319.12 & 942.11 & -0.4856 & 10.1429 & $\begin{array}{l}\text { agmatine }=>\text { putrescine }=>\text { spermidine } \\
\text { Polyamine biosynthesis, arginine }=>\end{array}$ & $\begin{array}{l}\text { biosynthesis } \\
\text { Polyamine }\end{array}$ & 0.14415 \\
\hline M00134 & 1179.53 & 635.459 & -0.8923 & 9.82575 & & & 0.15525 \\
\hline M00135 & 687.075 & 520.608 & -0.4003 & 9.23803 & $\begin{array}{l}\text { putrescine }=>\text { GABA } \\
\text { GABA biosynthesis, prokaryotes, }\end{array}$ & $\begin{array}{l}\text { biosynthesis } \\
\text { Polyamine }\end{array}$ & 0.59535 \\
\hline M0013 & 0.9583 & 0.26049 & -1.8792 & -0.7146 & $\begin{array}{l}\text { putrescine }=>\text { GABA } \\
\text { Flavanone biosynthesis, phenylalanine }\end{array}$ & $\begin{array}{l}\text { biosynthesis } \\
\text { Biosynthesis of }\end{array}$ & 0.59716 \\
\hline 00137 & 4.70302 & 2.86997 & -0.7126 & 1.92086 & $\begin{array}{l}\Rightarrow \text { naringenin } \\
\text { Flavonoid biosynthesis, naringenin }=>\end{array}$ & $\begin{array}{l}\text { secondary metabolites } \\
\text { Biosynthesis of }\end{array}$ & 0.199 \\
\hline M0013 & 1.01682 & 1.32217 & $0.3 / 883$ & 0.22589 & din & Secondary metabolites & $0.859 / 4$ \\
\hline & 15.64 & & & 12.0242 & nit interconversion, prokaryotes & (2) & \\
\hline M00141 & 6930 & 6861.64 & -0.0143 & 12.7515 & C1-unit interconversion, eukaryotes & Cofactor and vitamin & 0.93004 \\
\hline
\end{tabular}


biosynthesis

\begin{tabular}{|c|c|c|c|c|c|c|c|}
\hline M00142 & 3307.5 & 1128.35 & -1.5515 & 11.115 & $\begin{array}{l}\text { NADH:ubiquinone oxidoreductase, } \\
\text { mitochondria } \\
\text { NADH dehydrogenase (ubiquinone) Fe- }\end{array}$ & ATP synthesis & 0.00622 \\
\hline M00143 & 2276.55 & 4151.38 & 0.86675 & 11.6501 & $\begin{array}{l}S \text { protein/flavoprotein complex, } \\
\text { mitochondria }\end{array}$ & ATP synthesis & 0.71354 \\
\hline M00144 & 296.543 & 257.933 & -0.2012 & 8.11498 & $\begin{array}{l}\text { NADH:quinone oxidoreductase, } \\
\text { prokaryotes } \\
\text { NAD(P)H·quinone oxidoreductase }\end{array}$ & ATP synthesis & 0.09525 \\
\hline M00145 & 4.12588 & 140.359 & 5.08827 & 6.17477 & $\begin{array}{l}\text { chloroplasts and cyanobacteria } \\
\text { NADH dehydrogenase (ubiquinone) } 1\end{array}$ & ATP synthesis & 0.34274 \\
\hline M00146 & 1089.48 & 678.693 & -0.6828 & 9.78804 & $\begin{array}{l}\text { alpha subcomplex } \\
\text { NADH dehydrogenase (ubiquinone) } 1\end{array}$ & ATP synthesis & 0.03557 \\
\hline M00147 & 167.966 & 132.001 & -0.3476 & 7.22866 & beta subcomplex & ATP synthesis & 0.18916 \\
\hline M00148 & 3122.96 & 4408.1 & 0.49724 & 11.8786 & Succinate dehydrogenase (ubiquinone) & ATP synthesis & 0.28426 \\
\hline M00149 & 374.21 & 786.415 & 1.07144 & 9.18069 & Succinate dehydrogenase, prokaryotes & ATP synthesis & 0.81485 \\
\hline M00150 & 3.67537 & 18.2578 & 2.31255 & 3.45504 & $\begin{array}{l}\text { Fumarate reductase, prokaryotes } \\
\text { Cytochrome bc } 1 \text { complex respiratory }\end{array}$ & ATP synthesis & 0.27897 \\
\hline M00151 & 10940 & 20823.1 & 0.92857 & 13.9551 & unit & ATP synthesis & 0.41901 \\
\hline M00152 & 11641.2 & 21287.4 & 0.87076 & 14.0071 & Cytochrome bc1 complex & ATP synthesis & 0.25289 \\
\hline M00153 & 0.37566 & 0.61282 & 0.70604 & -1.0167 & Cytochrome d ubiquinol oxidase & ATP synthesis & 0.98543 \\
\hline M00154 & 11644.5 & 13952.7 & 0.2609 & 13.6437 & Cytochrome c oxidase & ATP synthesis & 0.45881 \\
\hline M00155 & 374.55 & 470.285 & 0.32838 & 8.72253 & Cytochrome c oxidase, prokaryotes & ATP synthesis & 0.82323 \\
\hline M00156 & 0.0346 & 1.10859 & 5.00169 & -0.8069 & Cytochrome c oxidase, cbb3-type & ATP synthesis & 0.73021 \\
\hline M00157 & 14309.3 & 8316.94 & -0.7828 & 13.4657 & chloroplasts & ATP synthesis & 0.13765 \\
\hline M00158 & 61795.3 & 41786.8 & -0.5644 & 15.6604 & F-type ATPase, eukaryotes & ATP synthesis & 0.08471 \\
\hline M00159 & 1.51378 & 6.74103 & 2.15481 & 2.04524 & V/A-type ATPase, prokaryotes & ATP synthesis & 0.39198 \\
\hline M00160 & 7678.96 & 4816.95 & -0.6728 & 12.6092 & V-type ATPase, eukaryotes & ATP synthesis & 0.29722 \\
\hline M00161 & 51818.7 & 27798 & -0.8985 & 15.2808 & Photosystem II & Photosynthesis & 0.02385 \\
\hline M00162 & 6995.23 & 3608.06 & -0.9551 & 12.3722 & Cytochrome b6f complex & ATP synthesis & 0.00089 \\
\hline M00163 & 13081.4 & 4314.49 & -1.6003 & 13.0865 & $\begin{array}{l}\text { Photosystem I } \\
\text { Reductive pentose phosphate cycle }\end{array}$ & Photosynthesis & 0.00039 \\
\hline M00165 & 448564 & 133435 & -1.7492 & 18.1507 & (Calvin cycle) & Carbon fixation & 8.07E-24 \\
\hline M00166 & 324198 & 96223.2 & -1.7524 & 17.6815 & $\begin{array}{l}\text { ribulose- } 5 \mathrm{P}=>\text { glyceraldehyde- } 3 \mathrm{P} \\
\text { Reductive pentose phosphate cycle, }\end{array}$ & Carbon fixation & $1.81 \mathrm{E}-16$ \\
\hline M00167 & 124366 & 37211.8 & -1.7408 & 16.3019 & & Carbon fixation & $1.29 \mathrm{E}-09$ \\
\hline M00168 & 12190.5 & 4655.01 & -1.3889 & 13.0401 & $\begin{array}{l}\text { dark } \\
\text { CAM (Crassulacean acid metabolism), }\end{array}$ & Carbon fixation & 0.00344 \\
\hline M00169 & 1471.05 & 9767.6 & 2.73116 & 12.4562 & $\begin{array}{l}\text { light } \\
\text { C4-dicarboxylic acid cycle, } \\
\text { phosphoenolpyruvate carboxykinase }\end{array}$ & Carbon fixation & $2.43 \mathrm{E}-05$ \\
\hline M00170 & 2571.74 & 2503.26 & -0.0389 & 11.3092 & $\begin{array}{l}\text { type } \\
\text { C4-dicarboxylic acid cycle, NAD - }\end{array}$ & Carbon fixation & 0.01603 \\
\hline M00171 & 14792.7 & 15060.5 & 0.02588 & 13.8656 & $\begin{array}{l}\text { malic enzyme type } \\
\text { C4-dicarboxylic acid cycle, NADP - }\end{array}$ & Carbon fixation & $9.42 \mathrm{E}-11$ \\
\hline M00172 & 2043.21 & 10679.4 & 2.38592 & 12.6351 & $\begin{array}{l}\text { malic enzyme type } \\
\text { Reductive citrate cycle (Arnon- }\end{array}$ & Carbon fixation & 0.00011 \\
\hline M00173 & 10242.1 & 19086.1 & 0.89801 & 13.84 & $\begin{array}{l}\text { Buchanan cycle) } \\
\text { Methane oxidation, methanotroph, }\end{array}$ & Carbon fixation & 0.33036 \\
\hline M00174 & 0.55413 & 0.03606 & -3.9416 & -1.7607 & $\begin{array}{l}\text { methane }=>\text { formaldehyde } \\
\text { Assimilatory sulfate reduction, sulfate }\end{array}$ & Methane metabolism & 0.17208 \\
\hline M00176 & 2616.53 & 2521.55 & -0.0533 & 11.327 & $\Rightarrow \mathrm{H} 2 \mathrm{~S}$ & Sulfur metabolism & 0.24312 \\
\hline M00177 & 527994 & 214885 & -1.297 & 18.5028 & Ribosome, eukaryotes & Ribosome & $4.52 \mathrm{E}-54$ \\
\hline M00178 & 28629.4 & 23080.2 & -0.3108 & 14.6581 & Ribosome, bacteria & Ribosome & $3.68 \mathrm{E}-05$ \\
\hline M00179 & 334187 & 148979 & -1.1655 & 17.8822 & Ribosome, archaea & Ribosome & $2.67 \mathrm{E}-24$ \\
\hline
\end{tabular}




\begin{tabular}{|c|c|c|c|c|c|c|c|}
\hline M00180 & 1316.72 & 1866.98 & 0.50376 & 10.6365 & RNA polymerase II, eukaryotes & RNA polymerase & 0.02906 \\
\hline M00181 & 1063.24 & 1213.7 & 0.19094 & 10.1529 & RNA polymerase III, eukaryotes & RNA polymerase & 0.32021 \\
\hline M00182 & 1076.55 & 1240.39 & 0.20437 & 10.178 & RNA polymerase I, eukaryotes & RNA polymerase & 0.47041 \\
\hline M00183 & 566.614 & 1140.26 & 1.00893 & 9.73714 & RNA polymerase, bacteria & RNA polymerase & 0.19638 \\
\hline M00184 & 3.52214 & 20.1099 & 2.51338 & 3.56267 & RNA polymerase, archaea & $\begin{array}{l}\text { RNA polymerase } \\
\text { Mineral and organic }\end{array}$ & 0.91256 \\
\hline M00185 & 3.78543 & 2.16399 & -0.8068 & 1.57275 & Sulfate transport system & $\begin{array}{l}\text { ion transport system } \\
\text { Mineral and organic }\end{array}$ & 0.95009 \\
\hline M00186 & 0.06806 & 0.5622 & 3.04617 & -1.666 & Tungstate transport system & $\begin{array}{l}\text { ion transport system } \\
\text { Mineral and organic }\end{array}$ & 0.89145 \\
\hline M00188 & 0.68934 & 8.32345 & 3.59389 & 2.17197 & NitT/TauT family transport system & $\begin{array}{l}\text { ion transport system } \\
\text { Mineral and organic }\end{array}$ & 0.51127 \\
\hline M00189 & 0.03149 & 1.32346 & 5.39312 & -0.5618 & Molybdate transport system & $\begin{array}{l}\text { ion transport system } \\
\text { Mineral and organic }\end{array}$ & 0.34683 \\
\hline M00190 & 0.75856 & 2.74121 & 1.85348 & 0.80726 & Iron(III) transport system & $\begin{array}{l}\text { ion transport system } \\
\text { Mineral and organic }\end{array}$ & 0.87174 \\
\hline M00191 & 0.53099 & 0.04197 & -3.6614 & -1.8035 & Thiamine transport system & $\begin{array}{l}\text { ion transport system } \\
\text { Mineral and organic }\end{array}$ & 0.16526 \\
\hline M00192 & 0.98156 & 0.01484 & -6.0477 & -1.0052 & $\begin{array}{l}\text { Putative thiamine transport system } \\
\text { Putative spermidine/putrescine transport }\end{array}$ & $\begin{array}{l}\text { ion transport system } \\
\text { Mineral and organic }\end{array}$ & 0.08015 \\
\hline M00193 & 23.0714 & 2.18179 & -3.4025 & 3.6584 & system & $\begin{array}{l}\text { ion transport system } \\
\text { Saccharide, polyol, } \\
\text { and lipid transport }\end{array}$ & 0.33014 \\
\hline M00194 & 2.61556 & 2.61556 & 0 & 1.38712 & $\begin{array}{l}\text { Maltose/maltodextrin transport system } \\
\text { Raffinose/stachyose/melibiose transport }\end{array}$ & $\begin{array}{l}\text { system } \\
\text { Saccharide, polyol, } \\
\text { and lipid transport }\end{array}$ & 1 \\
\hline M00196 & 2.65734 & 3.46833 & 0.38425 & 1.61487 & system & System Saccharide, polyol, & 1 \\
\hline M00197 & 2.61556 & 2.61556 & 0 & 1.38712 & $\begin{array}{l}\text { Putative fructooligosaccharide transport } \\
\text { system }\end{array}$ & $\begin{array}{l}\text { and lipid transport } \\
\text { system } \\
\text { Saccharide, polyol, }\end{array}$ & 1 \\
\hline M00198 & 0.11532 & 9.70325 & 6.39475 & 2.29551 & $\begin{array}{l}\text { Putative sn-glycerol-phosphate transport } \\
\text { system }\end{array}$ & $\begin{array}{l}\text { and lipid transport } \\
\text { system } \\
\text { Saccharide, polyol, }\end{array}$ & 0.46722 \\
\hline M00200 & 2.61556 & 2.61556 & 0 & 1.38712 & $\begin{array}{l}\text { Putative sorbitol/mannitol transport } \\
\text { system }\end{array}$ & $\begin{array}{l}\text { and lipid transport } \\
\text { system } \\
\text { Saccharide, polyol, } \\
\text { and lipid transport }\end{array}$ & 1 \\
\hline M00201 & 4.43052 & 3.71884 & -0.2526 & 2.02669 & alpha-Glucoside transport system & $\begin{array}{l}\text { system } \\
\text { Saccharide, polyol, } \\
\text { and lipid transport }\end{array}$ & 1 \\
\hline M00204 & 0.43472 & 1.12098 & 1.36661 & -0.3624 & Trehalose/maltose transport system & $\begin{array}{l}\text { system } \\
\text { Saccharide, polyol, } \\
\text { and lipid transport }\end{array}$ & 0.86035 \\
\hline M00206 & 2.61556 & 2.61556 & 0 & 1.38712 & Cellobiose transport system & $\begin{array}{l}\text { system } \\
\text { Saccharide, polyol, } \\
\text { and lipid transport }\end{array}$ & 1 \\
\hline M00207 & 4.90482 & 16.4029 & 1.74168 & 3.41331 & Putative multiple sugar transport system & $\begin{array}{l}\text { system } \\
\text { Mineral and organic }\end{array}$ & 1 \\
\hline M00208 & 0.02157 & 16.9118 & 9.61471 & 3.0818 & Glycine betaine/proline transport system & $\begin{array}{l}\text { ion transport system } \\
\text { Saccharide, polyol, } \\
\text { and lipid transport }\end{array}$ & 0.05347 \\
\hline M00210 & 5.38999 & 6.73085 & 0.32051 & 2.59942 & Phospholipid transport system & $\begin{array}{l}\text { system } \\
\text { Saccharide, polyol, } \\
\text { and lipid transport }\end{array}$ & 0.98182 \\
\hline M00211 & 0.38319 & 3.23264 & 3.0766 & 0.85433 & Putative $A B C$ transport system & $\begin{array}{l}\text { system } \\
\text { Saccharide, polyol, } \\
\text { and lipid transport }\end{array}$ & 0.57308 \\
\hline M00212 & 4.19272 & 0.84762 & -2.3064 & 1.33352 & Ribose transport system & $\begin{array}{l}\text { system } \\
\text { Saccharide, polyol, } \\
\text { and lipid transport }\end{array}$ & 0.69885 \\
\hline M00215 & 0.56667 & 0.11237 & -2.3343 & -1.5584 & D-Xylose transport system & $\begin{array}{l}\text { system } \\
\text { Saccharide, polyol, } \\
\text { and lipid transport }\end{array}$ & 0.36212 \\
\hline M00218 & 0.33514 & 0.87585 & 1.38593 & -0.7238 & Fructose transport system & $\begin{array}{l}\text { system } \\
\text { Saccharide, polyol, }\end{array}$ & 0.91038 \\
\hline M00220 & 0.30744 & 2.43319 & 2.98449 & 0.45451 & Rhamnose transport system & and lipid transport & 0.3961 \\
\hline
\end{tabular}




\begin{tabular}{|c|c|c|c|c|c|c|c|}
\hline M00221 & 0.33556 & 6.92499 & 4.36719 & 1.86008 & Putative simple sugar transport system & $\begin{array}{l}\text { and lipid transport } \\
\text { system }\end{array}$ & 0.76697 \\
\hline M00222 & 255.917 & 40.3041 & -2.6667 & 7.21053 & Phosphate transport system & $\begin{array}{l}\text { Phosphate and amino } \\
\text { acid transport system } \\
\text { Phosphate and amino }\end{array}$ & 0.26562 \\
\hline M00223 & 0.02538 & 2.66753 & 6.71589 & 0.42916 & Phosphonate transport system & acid transport system & 0.3243 \\
\hline M00225 & 0.05858 & 0.63235 & 3.43215 & -1.5334 & $\begin{array}{l}\text { Lysine/arginine/ornithine transport } \\
\text { system }\end{array}$ & $\begin{array}{l}\text { Phosphate and amino } \\
\text { acid transport system } \\
\text { Phosphate and amino }\end{array}$ & 0.86737 \\
\hline M00227 & 0.03743 & 0.99341 & 4.73003 & -0.9562 & Glutamine transport system & $\begin{array}{l}\text { acid transport system } \\
\text { Phosphate and amino }\end{array}$ & 0.76681 \\
\hline M00229 & 0.04826 & 0.74259 & 3.94369 & -1.3385 & Arginine transport system & $\begin{array}{l}\text { acid transport system } \\
\text { Phosphate and amino }\end{array}$ & 0.83111 \\
\hline M00230 & 1.88562 & 2.88285 & 0.61246 & 1.25353 & Glutamate/aspartate transport system & $\begin{array}{l}\text { acid transport system } \\
\text { Phosphate and amino }\end{array}$ & 0.67083 \\
\hline M00231 & 0.02672 & 2.13819 & 6.32242 & 0.11431 & Octopine/nopaline transport system & $\begin{array}{l}\text { acid transport system } \\
\text { Phosphate and amino }\end{array}$ & 0.56481 \\
\hline M00232 & 9.67435 & 19.4777 & 1.00959 & 3.86553 & General L-amino acid transport system & $\begin{array}{l}\text { acid transport system } \\
\text { Phosphate and amino }\end{array}$ & 0.69623 \\
\hline M00234 & 0.27552 & 1.20526 & 2.12912 & -0.4336 & Cystine transport system & $\begin{array}{l}\text { acid transport system } \\
\text { Phosphate and amino }\end{array}$ & 0.94707 \\
\hline M00235 & 0.04117 & 0.86803 & 4.39818 & -1.1373 & $\begin{array}{l}\text { Arginine/ornithine transport system } \\
\text { Putative polar amino acid transport }\end{array}$ & $\begin{array}{l}\text { acid transport system } \\
\text { Phosphate and amino }\end{array}$ & 0.80172 \\
\hline M00236 & 11.1949 & 19.8077 & 0.82322 & 3.95432 & $\begin{array}{l}\text { system } \\
\text { Branched-chain amino acid transport }\end{array}$ & $\begin{array}{l}\text { acid transport system } \\
\text { Phosphate and amino }\end{array}$ & 0.53593 \\
\hline M00237 & 21.3763 & 18.4827 & -0.2098 & 4.31684 & system & $\begin{array}{l}\text { acid transport system } \\
\text { Phosphate and amino }\end{array}$ & 0.99198 \\
\hline M00238 & 0.72195 & 0.52537 & -0.4586 & -0.6812 & D-Methionine transport system & $\begin{array}{l}\text { acid transport system } \\
\text { Peptide and nickel }\end{array}$ & 0.72107 \\
\hline M00239 & 6.00809 & 7.21505 & 0.2641 & 2.72499 & Peptides/nickel transport system & $\begin{array}{l}\text { transport system } \\
\text { Metallic cation, iron- } \\
\text { siderophore and } \\
\text { vitamin B12 transport }\end{array}$ & 0.99814 \\
\hline M00240 & 2.03602 & 1.20293 & -0.7592 & 0.69552 & Iron complex transport system & $\begin{array}{l}\text { system } \\
\text { Metallic cation, iron- } \\
\text { siderophore and } \\
\text { vitamin B12 transport }\end{array}$ & 0.62066 \\
\hline M00242 & 0.06388 & 2.76959 & 5.4381 & 0.50257 & Zinc transport system & $\begin{array}{l}\text { system } \\
\text { Metallic cation, iron- } \\
\text { siderophore and } \\
\text { vitamin B12 transport }\end{array}$ & 0.33589 \\
\hline M00243 & 0.03908 & 0.93433 & 4.57944 & -1.0389 & Manganese/iron transport system & $\begin{array}{l}\text { system } \\
\text { Metallic cation, iron- } \\
\text { siderophore and }\end{array}$ & 0.49548 \\
\hline M00244 & 5.13034 & 3.42852 & -0.5815 & 2.09742 & $\begin{array}{l}\text { Putative zinc/manganese transport } \\
\text { system }\end{array}$ & $\begin{array}{l}\text { vitamin B12 transport } \\
\text { system } \\
\text { ABC-2 type and other }\end{array}$ & 0.77764 \\
\hline M00250 & 0.10076 & 0.45053 & 2.16074 & -1.8591 & Lipopolysaccharide transport system & $\begin{array}{l}\text { transport systems } \\
\text { ABC-2 type and other }\end{array}$ & 0.93854 \\
\hline M00252 & 0.23778 & 0.23778 & 0 & -2.0723 & Lipooligosaccharide transport system & $\begin{array}{l}\text { transport systems } \\
\text { ABC-2 type and other }\end{array}$ & 0.93854 \\
\hline M00253 & 0.66191 & 0.751 & 0.18219 & -0.5013 & Sodium transport system & $\begin{array}{l}\text { transport systems } \\
\text { ABC-2 type and other }\end{array}$ & 0.46954 \\
\hline M00254 & 2.53712 & 8.8394 & 1.80076 & 2.50799 & ABC-2 type transport system & $\begin{array}{l}\text { transport systems } \\
\text { ABC-2 type and other }\end{array}$ & 0.40249 \\
\hline M00255 & 0.17666 & 1.01689 & 2.52515 & -0.7447 & Lipoprotein-releasing system & $\begin{array}{l}\text { transport systems } \\
\text { ABC-2 type and other }\end{array}$ & 0.94651 \\
\hline M00256 & 0.23778 & 0.23778 & 0 & -2.0723 & Cell division transport system & $\begin{array}{l}\text { transport systems } \\
\text { ABC-2 type and other }\end{array}$ & 0.93854 \\
\hline M00258 & 11.412 & 12.5044 & 0.13188 & 3.57992 & Putative $\mathrm{ABC}$ transport system & $\begin{array}{l}\text { transport systems } \\
\text { ABC-2 type and other }\end{array}$ & 0.81277 \\
\hline M00259 & 0.09692 & 0.46133 & 2.25099 & -1.841 & Heme transport system & transport systems & 0.93854 \\
\hline M00260 & 7.22558 & 12.6693 & 0.81015 & 3.31432 & $\begin{array}{l}\text { DNA polymerase III complex, bacteria } \\
\text { DNA polymerase alpha / primase }\end{array}$ & DNA polymerase & 0.55704 \\
\hline M00261 & 104.034 & 316.354 & 1.60448 & 7.71558 & complex & DNA polymerase & 0.04107 \\
\hline M00262 & 66.4178 & 162.147 & 1.28766 & 6.83646 & DNA polymerase delta complex & DNA polymerase & 0.70195 \\
\hline
\end{tabular}




\begin{tabular}{|c|c|c|c|c|c|c|c|}
\hline M00273 & 30.5909 & 0.47554 & 2.12047 & 6.35413 & $\begin{array}{l}\text { DNA polymerase epsilon complex } \\
\text { PTS system, fructose-specific II } \\
\text { component }\end{array}$ & $\begin{array}{l}\text { DNA polymerase } \\
\text { Phosphotransferase } \\
\text { system (PTS) }\end{array}$ & 0.06709 \\
\hline M00284 & 16.073 & 65.2389 & 2.0211 & 5.34539 & Origin recognition complex & Replication system & 0.09452 \\
\hline M00285 & 487.294 & 994.035 & 1.0285 & 9.53268 & MCM complex & Replication system & 0.0408 \\
\hline M00286 & 55.4237 & 86.409 & 0.64068 & 6.14805 & GINS complex & Replication system & 0.50561 \\
\hline M00288 & 385.511 & 965.562 & 1.3246 & 9.39989 & RPA complex & Replication system & 0.2054 \\
\hline M00289 & 230.158 & 841.295 & 1.86999 & 9.06535 & RF-C complex & Replication system & 0.00041 \\
\hline M00290 & 32.63 & 184.846 & 2.50206 & 6.76471 & Holo-TFIIH complex & Repair system & 0.00139 \\
\hline M00291 & 15.4505 & 209.399 & 3.76052 & 6.81282 & MRN complex & Repair system & 0.00544 \\
\hline M00292 & 13.1045 & 208.127 & 3.98933 & 6.78941 & MRX complex & Repair system & 0.00063 \\
\hline M00293 & 0.0512 & 5.92652 & 6.85494 & 1.57959 & DNA polymerase zeta complex & DNA polymerase & 0.11555 \\
\hline M00294 & 0.02152 & 18.4704 & 9.74521 & 3.20883 & $\begin{array}{l}\text { DNA polymerase gamma complex } \\
\text { BRCA1-associated genome surveillance }\end{array}$ & DNA polymerase & 0.13257 \\
\hline M00295 & 1044.46 & 2455.38 & 1.23319 & 10.7731 & complex (BASC) & Repair system & $1.00 \mathrm{E}-06$ \\
\hline M00296 & 86.3536 & 147.008 & 0.76757 & 6.86643 & BER complex & Repair system & 0.83877 \\
\hline M00297 & 13.8843 & 32.7346 & 1.23736 & 4.54284 & DNA-PK complex & $\begin{array}{l}\text { Repair system } \\
\text { Mineral and organic }\end{array}$ & 0.44947 \\
\hline M00299 & 0.07783 & 1.91606 & 4.62165 & -0.0044 & Spermidine/putrescine transport system & $\begin{array}{l}\text { ion transport system } \\
\text { Mineral and organic }\end{array}$ & 0.6481 \\
\hline M00300 & 0.23778 & 0.23778 & 0 & -2.0723 & $\begin{array}{l}\text { Putrescine transport system } \\
\text { Pyruvate oxidation, pyruvate }=>\text { acetyl- }\end{array}$ & $\begin{array}{l}\text { ion transport system } \\
\text { Central carbohydrate }\end{array}$ & 0.93854 \\
\hline M00307 & 5720.98 & 4015.05 & -0.5108 & 12.2491 & $\begin{array}{l}\text { CoA } \\
\text { Semi-phosphorylative Entner- }\end{array}$ & metabolism & 0.09233 \\
\hline M00308 & 180973 & 61353.7 & -1.5606 & 16.8866 & $\begin{array}{l}\text { Doudoroff pathway, gluconate }=> \\
\text { glycerate-3P } \\
\text { Non-phosphorylative Entner-Doudoroff }\end{array}$ & $\begin{array}{l}\text { Central carbohydrate } \\
\text { metabolism }\end{array}$ & $1.84 \mathrm{E}-08$ \\
\hline M00309 & 0.02632 & 1.92007 & 6.18866 & -0.0392 & $\begin{array}{l}\text { pathway, gluconate/galactonate }=> \\
\text { glycerate }\end{array}$ & $\begin{array}{l}\text { Central carbohydrate } \\
\text { metabolism } \\
\text { Metallic cation, iron- } \\
\text { siderophore and } \\
\text { vitamin B12 transport }\end{array}$ & 0.52715 \\
\hline M00319 & 0.0466 & 0.70737 & 3.92415 & -1.4074 & Manganese/zinc/iron transport system & $\begin{array}{l}\text { system } \\
\text { ABC-2 type and other }\end{array}$ & 0.89767 \\
\hline M00320 & 1.23097 & 0.09995 & -3.6225 & -0.5876 & Lipopolysaccharide export system & $\begin{array}{l}\text { transport systems } \\
\text { Phosphate and amino }\end{array}$ & 0.28564 \\
\hline M00323 & 1.90914 & 24.8001 & 3.69935 & 3.73926 & Urea transport system & $\begin{array}{l}\text { acid transport system } \\
\text { Peptide and nickel }\end{array}$ & 0.08751 \\
\hline M00324 & 0.03311 & 1.18819 & 5.16541 & -0.7116 & $\begin{array}{l}\text { Dipeptide transport system } \\
\text { alpha-Hemolysin/cyclolysin transport }\end{array}$ & $\begin{array}{l}\text { transport system } \\
\text { Bacterial secretion }\end{array}$ & 0.26786 \\
\hline M00325 & 1.11134 & 52.1109 & 5.55121 & 4.73396 & system & $\begin{array}{l}\text { system } \\
\text { Bacterial secretion }\end{array}$ & 0.00853 \\
\hline M00326 & 0.594 & 52.1286 & 6.45546 & 4.72035 & RTX toxin transport system & $\begin{array}{l}\text { system } \\
\text { Bacterial secretion }\end{array}$ & 0.02399 \\
\hline M00330 & 0.03544 & 1.07051 & 4.91674 & -0.8547 & Adhesin protein transport system & $\begin{array}{l}\text { system } \\
\text { Bacterial secretion }\end{array}$ & 0.45985 \\
\hline M00331 & 1.24219 & 4.29861 & 1.79098 & 1.4701 & Type II general secretion pathway & & 0.84158 \\
\hline M00332 & 0.10312 & 3.36307 & 5.02732 & 0.79335 & Type III secretion system & $\begin{array}{l}\text { system } \\
\text { Bacterial secretion }\end{array}$ & 0.85511 \\
\hline M00333 & 0.23778 & 0.23778 & 0 & -2.0723 & Type IV secretion system & $\begin{array}{l}\text { system } \\
\text { Bacterial secretion }\end{array}$ & 0.93854 \\
\hline M00334 & 4.76745 & 41.1247 & 3.10872 & 4.52017 & Type VI secretion system & $\begin{array}{l}\text { system } \\
\text { Bacterial secretion }\end{array}$ & 0.15797 \\
\hline M00335 & 1126.45 & 1050.78 & -0.1003 & 10.0883 & $\begin{array}{l}\text { Sec (secretion) system } \\
\text { Twin-arginine translocation (Tat) }\end{array}$ & $\begin{array}{l}\text { system } \\
\text { Bacterial secretion }\end{array}$ & 0.04717 \\
\hline M00336 & 129.26 & 77.9283 & -0.7301 & 6.6948 & system & system & 0.33916 \\
\hline M00337 & 5492.91 & 5480.8 & -0.0032 & 12.4218 & Immunoproteasome & Proteasome & 0.99977 \\
\hline M00338 & 357.473 & 547.426 & 0.61483 & 8.82161 & $\begin{array}{l}\text { Cysteine biosynthesis, homocysteine }+ \\
\text { serine }=>\text { cysteine }\end{array}$ & $\begin{array}{l}\text { methionine } \\
\text { metabolism }\end{array}$ & 0.42966 \\
\hline
\end{tabular}




\begin{tabular}{|c|c|c|c|c|c|c|c|}
\hline M00339 & 0.29039 & 52.4464 & 7.49669 & 4.72074 & RaxAB-RaxC type I secretion system & $\begin{array}{l}\text { Bacterial secretion } \\
\text { system }\end{array}$ & 0.00245 \\
\hline M00340 & 6211.41 & 6207.16 & -0.001 & 12.6002 & $\begin{array}{l}\text { Proteasome, } 20 \mathrm{~S} \text { core particle } \\
\text { Proteasome, 19S regulatory particle }\end{array}$ & Proteasome & 1 \\
\hline M00341 & 3016.86 & 3729.8 & 0.30605 & 11.72 & (PA700) & Proteasome & 0.96184 \\
\hline M00342 & 3.16467 & 1.5545 & -1.0256 & 1.23853 & Bacterial proteasome & Proteasome & 0.7463 \\
\hline M00343 & 3.2195 & 2.2132 & -0.5407 & 1.44167 & Archaeal proteasome & Proteasome & 0.75832 \\
\hline M00344 & 33175.3 & 21650.2 & -0.6157 & 14.7426 & $\begin{array}{l}\text { monophosphate pathway } \\
\text { Formaldehyde assimilation, ribulose }\end{array}$ & Methane metabolism & 0.06145 \\
\hline M00345 & 23326.2 & 19337.4 & -0.2706 & 14.3807 & $\begin{array}{l}\text { monophosphate pathway } \\
\text { Formaldehyde assimilation, serine }\end{array}$ & Methane metabolism & 0.0506 \\
\hline M00346 & 21170.8 & 14090.8 & -0.5873 & 14.1058 & $\begin{array}{l}\text { pathway } \\
\text { Capsaicin biosynthesis, L-Phenylalanine }\end{array}$ & $\begin{array}{l}\text { Methane metabolism } \\
\text { Aromatic amino acid }\end{array}$ & 0.30827 \\
\hline M00350 & 24.5562 & 257.673 & 3.39138 & 7.14072 & $\Rightarrow$ Capsaicin & metabolism & 0.08537 \\
\hline M00351 & 4191.28 & 4717.65 & 0.17068 & 12.121 & Spliceosome, U1-snRNP & Spliceosome & 0.99999 \\
\hline M00352 & 4595.49 & 5329.77 & 0.21385 & 12.2769 & Spliceosome, U2-snRNP & Spliceosome & 0.99989 \\
\hline M00353 & 24636.8 & 23729.3 & -0.0541 & 14.5617 & Spliceosome, Prp19/CDC5L complex & Spliceosome & 0.70257 \\
\hline M00354 & 5926.44 & 6827.11 & 0.20411 & 12.6386 & Spliceosome, U4/U6.U5 tri-snRNP & Spliceosome & 0.99999 \\
\hline M00355 & 29693.4 & 29671.5 & -0.0011 & 14.8573 & Spliceosome, 35S U5-snRNP & Spliceosome & 0.99983 \\
\hline M00356 & 1.2607 & 3.04715 & 1.27324 & 1.10697 & Methanogenesis, methanol $=>$ methane & Methane metabolism & 0.99997 \\
\hline M00357 & 189.474 & 392.89 & 1.05213 & 8.18578 & Methanogenesis, acetate $=>$ methane & Methane metabolism & 0.99754 \\
\hline M00358 & 0.7719 & 3.60251 & 2.22251 & 1.12909 & Coenzyme $\mathrm{M}$ biosynthesis & Methane metabolism & 0.07817 \\
\hline M00359 & 9958.27 & 7095.79 & -0.4889 & 13.0578 & $\begin{array}{l}\text { Aminoacyl-tRNA biosynthesis, } \\
\text { eukaryotes } \\
\text { Aminoacyl-tRNA biosynthesis, }\end{array}$ & Aminoacyl tRNA & 0.07305 \\
\hline M00360 & 9891.79 & 6957.26 & -0.5077 & 13.0404 & $\begin{array}{l}\text { prokaryotes } \\
\text { Nucleotide sugar biosynthesis, }\end{array}$ & Aminoacyl tRNA & 0.34653 \\
\hline M00361 & 7073.03 & 3092.87 & -1.1934 & 12.3115 & $\begin{array}{l}\text { eukaryotes } \\
\text { Nucleotide sugar biosynthesis, }\end{array}$ & Nucleotide sugar & 0.00207 \\
\hline M00362 & 7049.39 & 3066.85 & -1.2007 & 12.3044 & $\begin{array}{l}\text { prokaryotes } \\
\mathrm{C} 10-\mathrm{C} 20 \text { isoprenoid biosynthesis, }\end{array}$ & $\begin{array}{l}\text { Nucleotide sugar } \\
\text { Terpenoid backbone }\end{array}$ & 0.00105 \\
\hline M00364 & 671.246 & 642.583 & -0.063 & 9.35956 & $\begin{array}{l}\text { bacteria } \\
\text { C10-C20 isoprenoid biosynthesis, }\end{array}$ & $\begin{array}{l}\text { biosynthesis } \\
\text { Terpenoid backbone }\end{array}$ & 0.97725 \\
\hline M00365 & 176.508 & 230.824 & 0.38706 & 7.67006 & archaea & $\begin{array}{l}\text { biosynthesis } \\
\text { Terpenoid backbone }\end{array}$ & 0.96202 \\
\hline M00366 & 1026.2 & 793.239 & -0.3715 & 9.82928 & $\begin{array}{l}\mathrm{C} 10-\mathrm{C} 20 \text { isoprenoid biosynthesis, plants } \\
\mathrm{C} 10-\mathrm{C} 20 \text { isoprenoid biosynthesis, non- }\end{array}$ & $\begin{array}{l}\text { biosynthesis } \\
\text { Terpenoid backbone }\end{array}$ & 0.7135 \\
\hline M00367 & 537.524 & 390.934 & -0.4594 & 8.85869 & plant eukaryotes & $\begin{array}{l}\text { biosynthesis } \\
\text { Cysteine and }\end{array}$ & 0.62167 \\
\hline M00368 & 21307.8 & 13026.1 & -0.71 & 14.0673 & $\begin{array}{l}\text { Ethylene biosynthesis, methionine }=> \\
\text { ethylene } \\
\text { Castasterone biosynthesis, campesterol }\end{array}$ & $\begin{array}{l}\text { methionine } \\
\text { metabolism } \\
\text { Other terpenoid }\end{array}$ & 0.09953 \\
\hline M00371 & 0.13403 & 2.59585 & 4.27559 & 0.44884 & $\Rightarrow>$ castasterone & biosynthesis & 0.74319 \\
\hline M00372 & 192.787 & 496.909 & 1.36597 & 8.42982 & carotene $=>$ abscisic acid & $\begin{array}{l}\text { biosynthesis } \\
\text { Other carbohydrate }\end{array}$ & 0.72173 \\
\hline M00373 & 1211.04 & 881.341 & -0.4585 & 10.0309 & Ethylmalonyl pathway & metabolism & 0.25717 \\
\hline M00374 & 2910.4 & 3973.15 & 0.44907 & 11.7489 & $\begin{array}{l}\text { Dicarboxylate-hydroxybutyrate cycle } \\
\text { Hydroxypropionate-hydroxybutylate }\end{array}$ & Carbon fixation & 0.58676 \\
\hline M00375 & 882.592 & 410.788 & -1.1034 & 9.33693 & cycle & Carbon fixation & 0.98159 \\
\hline M00376 & 1362.14 & 1545.91 & 0.18258 & 10.5058 & $\begin{array}{l}\text { 3-Hydroxypropionate bi-cycle } \\
\text { Reductive acetyl-CoA pathway (Wood- }\end{array}$ & Carbon fixation & 0.127 \\
\hline M00377 & 642.322 & 393.506 & -0.7069 & 9.01657 & Ljungdahl pathway) & Carbon fixation & 0.69872 \\
\hline M00378 & 0.03099 & 1.33142 & 5.42511 & -0.5538 & F420 biosynthesis & Methane metabolism & 0.36128 \\
\hline M00379 & 7410.73 & 8397.72 & 0.18038 & 12.9484 & SCF-MET30 complex & Ubiquitin system & 0.99956 \\
\hline M00380 & 7412.21 & 8401.93 & 0.18082 & 12.9489 & SCF-BTRC complex & Ubiquitin system & 0.99969 \\
\hline M00381 & 7410.49 & 8398.04 & 0.18048 & 12.9484 & SCF-SKP2 complex & Ubiquitin system & 0.99955 \\
\hline M00382 & 7410.7 & 8394.96 & 0.17991 & 12.9482 & SCF-FBS complex & Ubiquitin system & 0.9999 \\
\hline
\end{tabular}




\begin{tabular}{|c|c|c|c|c|c|c|c|}
\hline M00383 & 1205.35 & 1124.13 & -0.1006 & 10.1858 & ECV complex & Ubiquitin system & 0.99938 \\
\hline M00384 & 1118.87 & 1159.1 & 0.05096 & 10.1535 & Cul3-SPOP complex & Ubiquitin system & 0.99521 \\
\hline M00385 & 1153.84 & 1160.35 & 0.00812 & 10.1763 & Cu14-DDB1-DDB2 complex & Ubiquitin system & 0.99919 \\
\hline M00386 & 1157.06 & 1163.89 & 0.0085 & 10.1805 & Cul4-DDB1-CSA complex & Ubiquitin system & 0.99919 \\
\hline M00387 & 7412.5 & 8400.84 & 0.18057 & 12.9489 & SCF-FBW7 complex & Ubiquitin system & 0.99974 \\
\hline M00388 & 143.172 & 99.4316 & -0.526 & 6.92246 & ECS complex & Ubiquitin system & 0.93921 \\
\hline M00389 & 118.031 & 247.278 & 1.06697 & 7.51298 & $\mathrm{APC} / \mathrm{C}$ complex & Ubiquitin system & 0.14051 \\
\hline M00390 & 68.8831 & 172.315 & 1.32283 & 6.91408 & Exosome, archaea & RNA processing & 0.30849 \\
\hline M00391 & 104.518 & 281.087 & 1.42727 & 7.59098 & Exosome, eukaryotes & RNA processing & 0.36862 \\
\hline M00392 & 45.7594 & 56.5753 & 0.3061 & 5.67715 & Ski complex & RNA processing & 0.58026 \\
\hline M00393 & 40.3816 & 99.6429 & 1.30307 & 6.12954 & TRAMP complex & RNA processing & 0.72638 \\
\hline M00394 & 12707.6 & 5676.63 & -1.1626 & 13.1662 & RNA degradosome & RNA processing & 0.00212 \\
\hline M00395 & 511.96 & 505.023 & -0.0197 & 8.99008 & Decapping complex & RNA processing & 0.39599 \\
\hline M00396 & 576.444 & 802.934 & 0.4781 & 9.4298 & Lsm 2-8 complex & Spliceosome & 0.95499 \\
\hline M00397 & 562.267 & 789.287 & 0.4893 & 9.4004 & Lsm 1-7 complex & Spliceosome & 0.94881 \\
\hline M00398 & 4134.61 & 4576.34 & 0.14645 & 12.0886 & Sm core complex & Spliceosome & 1 \\
\hline M00399 & 59.7198 & 96.5994 & 0.6938 & 6.28835 & Cap binding complex & Spliceosome & 0.60179 \\
\hline M00400 & 3760.75 & 2924.42 & -0.3629 & 11.7067 & p97-Ufd1-Npl4 complex & Protein processing & 0.94783 \\
\hline M00401 & 1567.83 & 1056.9 & -0.5689 & 10.358 & $\begin{array}{l}\text { Sec61 complex } \\
\text { Translocon-associated protein (TRAP) }\end{array}$ & Protein processing & 0.31619 \\
\hline M00402 & 547.912 & 325.085 & -0.7531 & 8.76983 & complex & Protein processing & 0.36119 \\
\hline M00403 & 3862.1 & 3124.68 & -0.3057 & 11.7704 & HRD1/SEL1 ERAD complex & Protein processing & 0.68512 \\
\hline M00404 & 913.947 & 1206.49 & 0.40063 & 10.0501 & COPII complex & Protein processing & 0.70012 \\
\hline M00405 & 100.788 & 144.254 & 0.51728 & 6.93689 & THC complex & RNA processing & 0.84746 \\
\hline M00406 & 2362.02 & 2262.99 & -0.0618 & 11.1752 & TREX complex & RNA processing & 0.81888 \\
\hline M00407 & 7414.01 & 8397.27 & 0.17967 & 12.9487 & SCF-CDC4 complex & Ubiquitin system & 0.9998 \\
\hline M00408 & 7.51366 & 3.69692 & -1.0232 & 2.48679 & ESCRT-0 complex & Protein processing & 0.51392 \\
\hline M00409 & 144.521 & 88.3294 & -0.7103 & 6.86326 & ESCRT-I complex & Protein processing & 0.29547 \\
\hline M00410 & 15.1563 & 35.863 & 1.24258 & 4.67297 & ESCRT-II complex & Protein processing & 0.39312 \\
\hline M00411 & 7412.8 & 8395.92 & 0.17967 & 12.9484 & SCF-GRR1 complex & Ubiquitin system & 0.99975 \\
\hline M00412 & 905.603 & 853.397 & -0.0857 & 9.78054 & ESCRT-III complex & Protein processing & 0.22675 \\
\hline M00413 & 2.08195 & 7.45687 & 1.84064 & 2.25381 & FA core complex & Repair system & 0.20509 \\
\hline M00414 & 37.5841 & 99.3321 & 1.40214 & 6.09715 & Bloom's syndrome complex & Repair system & 0.50694 \\
\hline M00415 & 473.953 & 320.978 & -0.5623 & 8.63469 & $\begin{array}{l}\text { Fatty acid biosynthesis, elongation, } \\
\text { endoplasmic reticulum } \\
\text { Cytochrome aa3-600 menaquinol }\end{array}$ & Fatty acid metabolism & 0.679 \\
\hline M00416 & 1.16695 & 6.23883 & 2.41853 & 1.88865 & oxidase & ATP synthesis & 0.33007 \\
\hline M00417 & 0.87568 & 0.05042 & -4.1184 & -1.1108 & Cytochrome o ubiquinol oxidase & ATP synthesis & 0.10571 \\
\hline M00419 & 0.41509 & 0.38243 & -0.1182 & -1.3264 & 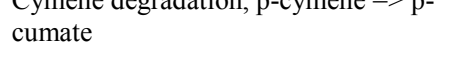 & $\begin{array}{l}\text { Aromatics } \\
\text { degradation }\end{array}$ & 0.83744 \\
\hline M00424 & 44.7963 & 11.1405 & -2.0076 & 4.80572 & Shelterin complex & Replication system & 0.41564 \\
\hline M00425 & 505.474 & 581.464 & 0.20205 & 9.08605 & H/ACA ribonucleoprotein complex & RNA processing & 0.94459 \\
\hline M00426 & 40.6402 & 46.204 & 0.18511 & 5.44036 & Survival motor neuron (SMN) complex & RNA processing & 0.92637 \\
\hline M00427 & 791.039 & 1283.56 & 0.69833 & 10.0186 & Nuclear pore complex & RNA processing & 0.45929 \\
\hline M00428 & 3890.62 & 2554.81 & -0.6068 & 11.6541 & $\begin{array}{l}\text { eIF4F complex } \\
\text { Competence-related DNA }\end{array}$ & $\begin{array}{l}\text { RNA processing } \\
\text { Bacterial secretion }\end{array}$ & 0.55334 \\
\hline M00429 & 7.68053 & 26.4522 & 1.78411 & 4.09308 & transformation transporter & & 0.38686 \\
\hline
\end{tabular}




\begin{tabular}{|c|c|c|c|c|c|c|c|}
\hline M00430 & 2840.47 & 2946.32 & 0.05278 & 11.4985 & Exon junction complex (EJC) & RNA processing & 0.14588 \\
\hline M00432 & 1266.73 & 293.568 & -2.1093 & 9.60761 & $\begin{array}{l}\text { Leucine biosynthesis, 2-oxoisovalerate } \\
=>2 \text {-oxoisocaproate } \\
\text { Lysine biosynthesis, } 2 \text {-oxoglutarate }=>\end{array}$ & $\begin{array}{l}\text { Branched-chain amino } \\
\text { acid metabolism }\end{array}$ & $8.24 \mathrm{E}-05$ \\
\hline M00433 & 10.5266 & 8.50763 & -0.3072 & 3.25053 & $\begin{array}{l}\text { 2-oxoadipate } \\
\text { PhoR-PhoB (phosphate starvation }\end{array}$ & Lysine metabolism & 0.99808 \\
\hline M00434 & 0.36562 & 2.85224 & 2.96367 & 0.6861 & $\begin{array}{l}\text { response) two-component regulatory } \\
\text { system }\end{array}$ & $\begin{array}{l}\text { Two-component } \\
\text { regulatory system } \\
\text { Mineral and organic }\end{array}$ & 0.73274 \\
\hline M00435 & 0.12056 & 0.40695 & 1.75505 & -1.9227 & Taurine transport system & $\begin{array}{l}\text { ion transport system } \\
\text { Mineral and organic }\end{array}$ & 0.93854 \\
\hline M00436 & 0.28046 & 1.06684 & 1.92751 & -0.5699 & Sulfonate transport system & $\begin{array}{l}\text { ion transport system } \\
\text { Mineral and organic }\end{array}$ & 0.91849 \\
\hline M00438 & 0.22378 & 3.52495 & 3.97742 & 0.9064 & Nitrate/nitrite transport system & $\begin{array}{l}\text { ion transport system } \\
\text { Peptide and nickel }\end{array}$ & 0.79622 \\
\hline M00439 & 0.31657 & 0.76011 & 1.26369 & -0.8934 & Oligopeptide transport system & $\begin{array}{l}\text { transport system } \\
\text { Peptide and nickel }\end{array}$ & 0.97886 \\
\hline M00440 & 0.10749 & 0.43474 & 2.01597 & -1.883 & $\begin{array}{l}\text { Nickel transport system } \\
\text { PhoQ-PhoP (magnesium transport) two- }\end{array}$ & $\begin{array}{l}\text { transport system } \\
\text { Two-component }\end{array}$ & 0.93854 \\
\hline M00444 & 0.19511 & 7.52526 & 5.26935 & 1.94867 & $\begin{array}{l}\text { component regulatory system } \\
\text { EnvZ-OmpR (osmotic stress response) }\end{array}$ & regulatory system & 0.63992 \\
\hline M00445 & 0.27976 & 1.41177 & 2.33525 & -0.2417 & $\begin{array}{l}\text { two-component regulatory system } \\
\text { CusS-CusR (copper tolerance) two- }\end{array}$ & $\begin{array}{l}\text { regulatory system } \\
\text { Two-component }\end{array}$ & 0.99624 \\
\hline M00452 & 0.34311 & 2.09679 & 2.61146 & 0.28682 & $\begin{array}{l}\text { component regulatory system } \\
\text { KdpD-KdpE (potassium transport) two- }\end{array}$ & $\begin{array}{l}\text { regulatory system } \\
\text { Two-component }\end{array}$ & 0.99806 \\
\hline M00454 & 0.23778 & 0.23778 & -0.6058 & -2.0723 & $\begin{array}{l}\text { component regulatory system } \\
\text { TorS-TorR (TMAO respiration) two- } \\
\text { component regulatory system }\end{array}$ & $\begin{array}{l}\text { regulatory system } \\
\text { Two-component } \\
\text { regulatory system }\end{array}$ & 0.93854 \\
\hline M00456 & 0.23778 & 0.23778 & 0 & -2.0723 & $\begin{array}{l}\text { ArcB-ArcA (anoxic redox control) two- } \\
\text { component regulatory system } \\
\text { ResE-ResD (aerobic and anaerobic }\end{array}$ & $\begin{array}{l}\text { Two-component } \\
\text { regulatory system }\end{array}$ & 0.93854 \\
\hline M00458 & 0.7441 & 0.02174 & -5.0968 & -1.3849 & $\begin{array}{l}\text { respiration) two-component regulatory } \\
\text { system } \\
\text { VicK-VicR (cell wall metabolism) two- }\end{array}$ & $\begin{array}{l}\text { Two-component } \\
\text { regulatory system }\end{array}$ & 0.11197 \\
\hline M00459 & 0.16958 & 8.45252 & 5.63938 & 2.10804 & $\begin{array}{l}\text { component regulatory system } \\
\text { SasA-RpaAB (circadian timing }\end{array}$ & $\begin{array}{l}\text { Iwo-component } \\
\text { regulatory system }\end{array}$ & 0.62805 \\
\hline M00472 & 0.07548 & 0.53385 & 2.82219 & -1.7147 & & regulatory system & 0.90142 \\
\hline M00473 & 0.09748 & 0.45868 & 2.23425 & -1.8464 & $\begin{array}{l}\text { uptake) two-component regulatory } \\
\text { system } \\
\text { RcsC-RcsD-RcsB (capsule synthesis) }\end{array}$ & $\begin{array}{l}\text { Two-component } \\
\text { regulatory system } \\
\text { Two-component }\end{array}$ & 0.93854 \\
\hline M00474 & 0.33205 & 2.44135 & 2.87822 & 0.47165 & $\begin{array}{l}\text { two-component regulatory system } \\
\text { BarA-UvrY (central carbon }\end{array}$ & regulatory system & 0.62268 \\
\hline M00475 & 0.23778 & 0.23778 & 0 & -2.0723 & $\begin{array}{l}\text { metabolism) two-component regulatory } \\
\text { system } \\
\text { DegS-DegU (multicellular behavior }\end{array}$ & $\begin{array}{l}\text { Two-component } \\
\text { regulatory system }\end{array}$ & 0.93854 \\
\hline M00478 & 0.05065 & 0.70108 & 3.79088 & -1.4117 & & $\begin{array}{l}\text { Two-component } \\
\text { regulatory system }\end{array}$ & 0.85081 \\
\hline M00479 & 0.23778 & 0.23778 & 0 & -2.0723 & $\begin{array}{l}\text { regulation) two-component regulatory } \\
\text { system } \\
\text { NreB-NreC (dissimilatory nitrate/nitrite }\end{array}$ & $\begin{array}{l}\text { Two-component } \\
\text { regulatory system }\end{array}$ & 0.93854 \\
\hline M00483 & 0.03908 & 0.84323 & 4.43131 & -1.1806 & $\begin{array}{l}\text { reduction) two-component regulatory } \\
\text { system } \\
\text { KinABCDE-Spo0FA (sporulation }\end{array}$ & $\begin{array}{l}\text { Two-component } \\
\text { regulatory system }\end{array}$ & 0.86981 \\
\hline M00485 & 0.03031 & 1.46382 & 5.59388 & -0.4207 & $\begin{array}{l}\text { control) two-component regulatory } \\
\text { system } \\
\text { arabinogalactan } \\
\text { oligomer/maltooligosaccharide transport }\end{array}$ & $\begin{array}{l}\text { Two-component } \\
\text { regulatory system } \\
\text { Saccharide, polyol, } \\
\text { and lipid transport }\end{array}$ & 0.66293 \\
\hline 1M0049 & 2.61556 & 100777 & 17000 & 0070 & $\begin{array}{l}\text { system } \\
\text { GlnL-GlnG (nitrogen regulation) two- }\end{array}$ & Two-component & 0.1720 \\
\hline M00497 & 0.0374 & 0.97775 & 4.70828 & -0.9783 & & & 0.47386 \\
\hline M00498 & 0.04807 & 0.73951 & 3.9435 & -1.3445 & $\begin{array}{l}\text { component regulatory system } \\
\text { PilS-PilR (type } 4 \text { fimbriae synthesis) }\end{array}$ & $\begin{array}{l}\text { regulatory system } \\
\text { Two-component }\end{array}$ & 0.83139 \\
\hline M00501 & 0.02166 & 14.8356 & 9.42013 & 2.8931 & two-component regulatory system & regulatory system & 0.16228 \\
\hline
\end{tabular}




\begin{tabular}{|c|c|c|c|c|c|c|c|}
\hline M00506 & 6.01222 & 7.08529 & 0.23693 & 2.71122 & $\begin{array}{l}\text { CheA-CheYBV (chemotaxis) two- } \\
\text { component regulatory system }\end{array}$ & $\begin{array}{l}\text { Two-component } \\
\text { regulatory system } \\
\text { Two-component }\end{array}$ & 0.8626 \\
\hline M00507 & 0.68098 & 2.81994 & 2.04999 & 0.80773 & $\begin{array}{l}\text { ChpA-ChpB/PilGH (chemosensory) } \\
\text { two-component regulatory system }\end{array}$ & $\begin{array}{l}\text { Two-component } \\
\text { regulatory system }\end{array}$ & 0.21173 \\
\hline M00511 & 0.82678 & 1.33741 & 0.69387 & 0.11383 & $\begin{array}{l}\text { PleC-PleD (cell fate control) two- } \\
\text { component regulatory system } \\
\text { CckA-CtrA/CpdR (cell cycle control) }\end{array}$ & $\begin{array}{l}\text { Two-component } \\
\text { regulatory system } \\
\text { Two-component }\end{array}$ & 0.97575 \\
\hline M00512 & 0.57627 & 0.92545 & 0.6834 & -0.4134 & $\begin{array}{l}\text { two-component regulatory system } \\
\text { LuxQN/CqsS-LuxU-LuxO (quorum }\end{array}$ & regulatory system & 0.99623 \\
\hline M00513 & 0.11374 & 0.42033 & 1.88578 & -1.9049 & $\begin{array}{l}\text { sensing) two-component regulatory } \\
\text { system } \\
\text { FlrB-FlrC (polar flagellar synthesis) }\end{array}$ & $\begin{array}{l}\text { Two-component } \\
\text { regulatory system } \\
\text { Two-component }\end{array}$ & 0.93854 \\
\hline M00515 & 0.28584 & 0.97729 & 1.77356 & -0.663 & $\begin{array}{l}\text { two-component regulatory system } \\
\text { SLN1-YPD1-SSK1/SKN7 }\end{array}$ & regulatory system & 0.9616 \\
\hline M00516 & 3.32545 & 1.0383 & -1.6793 & 1.12557 & $\begin{array}{l}\text { (osmosensing) two-component } \\
\text { regulatory system } \\
\text { YesM-YesN two-component regulatory }\end{array}$ & $\begin{array}{l}\text { Two-component } \\
\text { regulatory system } \\
\text { Two-component }\end{array}$ & 0.27264 \\
\hline M00519 & 0.16215 & 1.0391 & 2.67996 & -0.7355 & $\begin{array}{l}\text { system } \\
\text { ChvG-ChvI (acidity sensing) two- }\end{array}$ & $\begin{array}{l}\text { regulatory system } \\
\text { Two-component }\end{array}$ & 0.97579 \\
\hline M00520 & 0.79814 & 8.37223 & 3.3909 & 2.19698 & $\begin{array}{l}\text { component regulatory system } \\
\text { RegB-RegA (redox response) two- }\end{array}$ & $\begin{array}{l}\text { regulatory system } \\
\text { Two-component }\end{array}$ & 0.27752 \\
\hline M00523 & 0.75195 & 0.01878 & -5.3233 & -1.3757 & $\begin{array}{l}\text { component regulatory system } \\
\text { FixL-FixJ (nitrogen fixation) two- }\end{array}$ & $\begin{array}{l}\text { regulatory system } \\
\text { Two-component }\end{array}$ & 0.12731 \\
\hline M00524 & 2.08165 & 0.3307 & -2.6541 & 0.27044 & $\begin{array}{l}\text { component regulatory system } \\
\text { Lysine biosynthesis, acetyl-DAP }\end{array}$ & regulatory system & 0.26318 \\
\hline M00525 & 3726.6 & 1371.13 & -1.4425 & 11.3156 & $\begin{array}{l}\text { pathway, aspartate }=>\text { lysine } \\
\text { Lysine biosynthesis, DAP }\end{array}$ & Lysine metabolism & 0.00018 \\
\hline M00526 & 4086.18 & 1858 & -1.137 & 11.5373 & $\begin{array}{l}\text { dehydrogenase pathway, aspartate => } \\
\text { lysine } \\
\text { Lysine biosynthesis, DAP }\end{array}$ & Lysine metabolism & 0.05256 \\
\hline M00527 & 4508.8 & 2076.03 & -1.1189 & 11.6849 & lysine & Lysine metabolism & 0.06826 \\
\hline M00529 & 2.68246 & 1.15309 & -1.2181 & 0.93943 & $\begin{array}{l}\text { Denitrification, nitrate }=>\text { nitrogen } \\
\text { Dissimilatory nitrate reduction, nitrate }\end{array}$ & Nitrogen metabolism & 0.33417 \\
\hline M00530 & 37.5107 & 156.259 & 2.05856 & 6.5982 & $\begin{array}{l}\Rightarrow>\text { ammonia } \\
\text { Assimilatory nitrate reduction, nitrate }\end{array}$ & Nitrogen metabolism & 0.0452 \\
\hline M00531 & 170.816 & 1593.53 & 3.22171 & 9.78492 & $\Rightarrow>$ ammonia & $\begin{array}{l}\text { Nitrogen metabolism } \\
\text { Other carbohydrate }\end{array}$ & 0.09273 \\
\hline M00532 & 120485 & 41024.7 & -1.5543 & 16.3013 & $\begin{array}{l}\text { Photorespiration } \\
\text { Homoprotocatechuate degradation, } \\
\text { homoprotocatechuate =>2-oxohept-3- }\end{array}$ & metabolism & 0.01589 \\
\hline M00533 & 0.81743 & 1.05356 & 0.3661 & -0.0962 & $\begin{array}{l}\text { enedioate } \\
\text { Isoleucine biosynthesis, pyruvate }=>2 \text { - }\end{array}$ & & 0.48458 \\
\hline M00535 & 892.107 & 80.1581 & -3.4763 & 8.92521 & $\begin{array}{l}\text { oxobutanoate } \\
\text { Xylene degradation, xylene }=>\end{array}$ & $\begin{array}{l}\text { acid metabolism } \\
\text { Aromatics }\end{array}$ & 3.44E-05 \\
\hline M00537 & 1.32249 & 0.05195 & -4.6699 & -0.5412 & $\begin{array}{l}\text { methylbenzoate } \\
\text { Toluene degradation, toluene } \Rightarrow>\end{array}$ & $\begin{array}{l}\text { degradation } \\
\text { Aromatics }\end{array}$ & 0.05061 \\
\hline M00538 & 1.32249 & 0.05195 & -4.6699 & -0.5412 & $\begin{array}{l}\text { benzoate } \\
\text { Benzoate degradation, } \\
\text { cyclohexanecarboxylic acid }\end{array}$ & degradation & 0.05061 \\
\hline M00540 & 0.03504 & 1.05849 & 4.91672 & -0.871 & $\begin{array}{l}\Rightarrow \text { pimeloyl-CoA } \\
\text { EHEC/EPEC pathogenicity signature, }\end{array}$ & & 0.76199 \\
\hline M00542 & 0.10312 & 3.36307 & 5.02732 & 0.79335 & $\begin{array}{l}\text { T3SS and effectors } \\
\text { Biphenyl degradation, biphenyl => 2- }\end{array}$ & $\begin{array}{l}\text { Pathogenicity } \\
\text { Aromatics }\end{array}$ & 0.85511 \\
\hline M00545 & 46.9153 & 13.8042 & -1.765 & 4.92409 & $\begin{array}{l}\text { oxopent- } 4 \text {-enoate }+ \text { benzoate } \\
\text { Trans-cinnamate degradation, trans- } \\
\text { cinnamate }=>\text { acetyl-CoA }\end{array}$ & $\begin{array}{l}\text { degradation } \\
\text { Aromatic amino acid } \\
\text { metabolism }\end{array}$ & 0.56197 \\
\hline M00546 & 85.8497 & 179.045 & 1.06044 & 7.04928 & $\begin{array}{l}\text { Purine degradation, xanthine }=>\text { urea } \\
\text { Benzene degradation, benzene }=>\end{array}$ & $\begin{array}{l}\text { Purine metabolism } \\
\text { Aromatics }\end{array}$ & 0.56513 \\
\hline M00548 & 0.23778 & 0.23778 & 0 & -2.0723 & $\begin{array}{l}\text { catechol } \\
\text { Nucleotide sugar biosynthesis, glucose }\end{array}$ & degradation & 0.93854 \\
\hline M00549 & 2716.62 & 1077 & -1.3348 & 10.8894 & $\begin{array}{l}\text { => UDP-glucose } \\
\text { D-galactonate degradation, De Ley- }\end{array}$ & Sugar metabolism & 0.03945 \\
\hline M00552 & 180892 & 61210.5 & -1.5633 & 16.8853 & $\begin{array}{l}\text { Doudoroff pathway, D-galactonate }=> \\
\text { glycerate-3P } \\
\text { Nucleotide sugar biosynthesis, galactose }\end{array}$ & $\begin{array}{l}\text { Other carbohydrate } \\
\text { metabolism }\end{array}$ & 4.53E-09 \\
\hline M00554 & 96.8947 & 161.953 & 0.74108 & 7.01596 & $=>$ UDP-galactose & $\begin{array}{l}\text { Sugar metabolism } \\
\text { Serine and threonine }\end{array}$ & 0.1762 \\
\hline M00555 & 40.7664 & 44.345 & 0.12139 & 5.41128 & Betaine biosynthesis, choline $\Rightarrow$ betaine & metabolism & 0.09165 \\
\hline
\end{tabular}




\begin{tabular}{|c|c|c|c|c|c|c|c|}
\hline M00563 & 1.2607 & 3.04715 & 1.27324 & 1.10697 & $\begin{array}{l}\text { methylamine/dimethylamine/trimethyla } \\
\text { mine => methane } \\
\text { Trehalose biosynthesis, D-glucose 1P }\end{array}$ & Methane metabolism & 0.99997 \\
\hline M00565 & 2980.76 & 1908.5 & -0.6432 & 11.2554 & $\Rightarrow>$ trehalose & Sugar metabolism & 0.7423 \\
\hline M00567 & 1.2607 & 3.04715 & 1.27324 & 1.10697 & Methanogenesis, $\mathrm{CO} 2=>$ methane & Methane metabolism & 0.99997 \\
\hline M00568 & 0.33991 & 0.6843 & 1.00949 & -0.9655 & $\begin{array}{l}\text { oxoadipate } \\
\text { Catechol meta-cleavage, catechol }=>\end{array}$ & $\begin{array}{l}\text { Aromatics } \\
\text { degradation }\end{array}$ & 0.98543 \\
\hline M00569 & 46.8968 & 9.0555 & -2.3726 & 4.80613 & $\begin{array}{l}\text { acetyl-CoA / 4-methylcatechol => } \\
\text { propanoyl-CoA } \\
\text { Isoleucine biosynthesis, threonine }=>2 \text { - }\end{array}$ & $\begin{array}{l}\text { Aromatics } \\
\text { degradation } \\
\text { Branched-chain amino }\end{array}$ & 0.52732 \\
\hline M00570 & 5015.71 & 2442.75 & -1.0379 & 11.8647 & $\begin{array}{l}\text { oxobutanoate }=>\text { isoleucine } \\
\text { AlgE-type Mannuronan C-5-Epimerase }\end{array}$ & $\begin{array}{l}\text { acid metabolism } \\
\text { Bacterial secretion }\end{array}$ & 0.1626 \\
\hline M00571 & 0.25551 & 51.4409 & 7.6534 & 4.69199 & $\begin{array}{l}\text { transport system } \\
\text { Pimeloyl-ACP biosynthesis, BioC-BioH }\end{array}$ & system & 0.00104 \\
\hline M00572 & 2817.15 & 1093.38 & -1.3654 & 10.9331 & $\begin{array}{l}\text { pathway, malonyl-ACP }=>\text { pimeloyl- } \\
\text { ACP } \\
\text { Biotin biosynthesis, BioI pathway, long- }\end{array}$ & $\begin{array}{l}\text { Cofactor and vitamin } \\
\text { biosynthesis }\end{array}$ & 0.011 \\
\hline M00573 & 212.804 & 98.8885 & -1.1056 & 7.28398 & $\begin{array}{l}\text { chain-acyl-ACP }=>\text { pimeloyl-ACP }=> \\
\text { biotin } \\
\text { Pertussis pathogenicity signature } 2\end{array}$ & $\begin{array}{l}\text { Cofactor and vitamin } \\
\text { biosynthesis }\end{array}$ & 0.55826 \\
\hline M00575 & 1.11134 & 52.1109 & 5.55121 & 4.73396 & $\begin{array}{l}\text { T1SS } \\
\text { Biotin hiosynthesis BioW nathway }\end{array}$ & Pathogenicity & 0.00853 \\
\hline M00577 & 212.804 & 98.8885 & -1.1056 & 7.28398 & $\begin{array}{l}\text { pimelate }=>\text { pimeloyl-CoA }=>\text { biotin } \\
\text { Phosphate acetyltransferase-acetate }\end{array}$ & $\begin{array}{l}\text { biosynthesis } \\
\text { biamin }\end{array}$ & 0.55826 \\
\hline M00579 & 3.72295 & 83.0529 & 4.47951 & 5.43922 & kinase pathway, acetyl-CoA $\Rightarrow>$ acetate & $\begin{array}{l}\text { Carbon fixation } \\
\text { Central carbohydrate }\end{array}$ & 0.46956 \\
\hline M00580 & 3879.13 & 755.521 & -2.3602 & 11.1782 & fructose $6 \mathrm{P}=>$ ribose $5 \mathrm{P}$ & $\begin{array}{l}\text { metabolism } \\
\text { Metallic cation, iron- } \\
\text { siderophore and } \\
\text { vitamin B12 transport }\end{array}$ & $8.66 \mathrm{E}-09$ \\
\hline M00581 & 0.06809 & 2.20465 & 5.01689 & 0.18444 & Biotin transport system & $\begin{array}{l}\text { system } \\
\text { Metallic cation, iron- } \\
\text { siderophore and } \\
\text { vitamin B12 transport }\end{array}$ & 0.50422 \\
\hline M00582 & 0.50852 & 3.29839 & 2.69739 & 0.92862 & Energy-coupling factor transport system & $\begin{array}{l}\text { system } \\
\text { Phosphate and amino }\end{array}$ & 0.92609 \\
\hline M00586 & 0.02528 & 2.6631 & 6.71872 & 0.42674 & $\begin{array}{l}\text { Putative amino-acid transport system } \\
\text { Thiosulfate oxidation by SOX complex, }\end{array}$ & acid transport system & 0.39972 \\
\hline M00595 & 1392.64 & 1071.72 & -0.3779 & 10.267 & $\begin{array}{l}\text { thiosulfate }=>\text { sulfate } \\
\text { Dissimilatory sulfate reduction, sulfate }\end{array}$ & Sulfur metabolism & 0.45186 \\
\hline M00596 & 1704.53 & 1573.3 & -0.1156 & 10.6785 & $\Rightarrow \mathrm{H} 2 \mathrm{~S}$ & Sulfur metabolism & 0.78843 \\
\hline M00597 & 0.09272 & 1.56291 & 4.07514 & -0.2726 & Anoxygenic photosystem II & $\begin{array}{l}\text { Photosynthesis } \\
\text { Saccharide, polyol, } \\
\text { and lipid transport }\end{array}$ & 0.90932 \\
\hline M00599 & 0.65714 & 0.02628 & -4.6441 & -1.5492 & Inositol-phosphate transport system & $\begin{array}{l}\text { system } \\
\text { Saccharide, polyol, } \\
\text { and lipid transport }\end{array}$ & 0.12287 \\
\hline M00602 & 2.61556 & 2.61556 & 0 & 1.38712 & Arabinosaccharide transport system & $\begin{array}{l}\text { system } \\
\text { Saccharide, polyol, } \\
\text { and lipid transport }\end{array}$ & 1 \\
\hline M00605 & 3.00516 & 3.95918 & 0.39776 & 1.79999 & $\begin{array}{l}\text { Glucose/mannose transport system } \\
\text { N,N'-Diacetylchitobiose transport }\end{array}$ & $\begin{array}{l}\text { system } \\
\text { Saccharide, polyol, } \\
\text { and lipid transport }\end{array}$ & 1 \\
\hline M00606 & 2.61556 & 2.61556 & 0 & 1.38712 & & $\begin{array}{l}\text { system } \\
\text { Saccharide, polyol, } \\
\text { and lipid transport }\end{array}$ & 1 \\
\hline M00607 & 3.14047 & 23.1086 & 2.87938 & 3.71419 & $\begin{array}{l}\text { Glycerol transport system } \\
\text { 2-Oxocarboxylic acid chain extension, } \\
\text { 2-oxoglutarate }=>\text { 2-oxoadipate }=>2 \text { - }\end{array}$ & system & 0.35951 \\
\hline M00609 & 21307.1 & 13027.4 & 3.25537 & -1.5858 & $\begin{array}{l}\text { oxopimelate }=>2 \text {-oxosuberate } \\
\text { Cysteine biosynthesis, methionine }=> \\
\text { cysteine }\end{array}$ & $\begin{array}{l}\text { Methane metabolism } \\
\text { Cysteine and } \\
\text { methionine } \\
\text { metabolism }\end{array}$ & 0.88239 \\
\hline M00615 & 639.796 & 2955.56 & 2.20775 & 10.8119 & Nitrate assimilation & Metabolic capacity & 0.06319 \\
\hline M00620 & 891.242 & 973.939 & 0.12801 & 9.8651 & acetyl-CoA $=>$ oxoglutarate & Carbon fixation & 0.65518 \\
\hline
\end{tabular}




\begin{tabular}{|c|c|c|c|c|c|c|c|}
\hline M00622 & 0.71257 & 16.3755 & 4.52237 & 3.09491 & $\begin{array}{l}\text { Nicotinate degradation, nicotinate }=> \\
\text { fumarate }\end{array}$ & $\begin{array}{l}\text { Cofactor and vitamin } \\
\text { biosynthesis }\end{array}$ & 0.52531 \\
\hline M00625 & 0.58089 & 0.03358 & -4.1127 & -1.7026 & Methicillin resistance & Drug resistance & 0.1404 \\
\hline M00627 & 1.47587 & 2.5483 & 0.78797 & 1.00869 & beta-Lactam resistance, Bla system & Drug resistance & 0.76136 \\
\hline M00628 & 0.14996 & 2.30936 & 3.94486 & 0.29826 & $\begin{array}{l}\text { beta-Lactam resistance, AmpC system } \\
\text { D-Galacturonate degradation (bacteria), }\end{array}$ & Drug resistance & 0.882 \\
\hline M00631 & 8.07671 & 126.649 & 3.97093 & 6.07388 & $\begin{array}{l}\text { D-galacturonate }=>\text { pyruvate }+ \text { D- } \\
\text { glyceraldehyde } 3 \mathrm{P}\end{array}$ & $\begin{array}{l}\text { Other carbohydrate } \\
\text { metabolism }\end{array}$ & 0.51732 \\
\hline M00632 & 550.512 & 476.042 & -0.2097 & 9.00359 & $\begin{array}{l}\text { Galactose degradation, Leloir pathway, } \\
\text { galactose => alpha-D-glucose-1P } \\
\text { Semi-phosphorylative Entner- }\end{array}$ & $\begin{array}{l}\text { Other carbohydrate } \\
\text { metabolism }\end{array}$ & 0.04125 \\
\hline M00633 & 73.6306 & 25.1821 & -1.5479 & 5.62662 & $\begin{array}{l}\text { Doudoroff pathway, } \\
\text { gluconate/galactonate }=>\text { glycerate-3P } \\
\text { Multidrug resistance, efflux pump }\end{array}$ & $\begin{array}{l}\text { Central carbohydrate } \\
\text { metabolism } \\
\text { Drug efflux }\end{array}$ & 0.09149 \\
\hline M00646 & 0.25551 & 51.4409 & 7.6534 & 4.69199 & $\begin{array}{l}\text { AcrAD-TolC } \\
\text { Multidrug resistance, efflux pump }\end{array}$ & $\begin{array}{l}\text { transporter/pump } \\
\text { Drug efflux }\end{array}$ & 0.00104 \\
\hline M00647 & 0.25551 & 51.4409 & 7.6534 & 4.69199 & $\begin{array}{l}\text { AcrAB-TolC/SmeDEF } \\
\text { Vancomycin resistance, D-Ala-D-Lac }\end{array}$ & transporter/pump & 0.00104 \\
\hline M00651 & 0.14907 & 0.35642 & 1.25761 & -1.9843 & $\begin{array}{l}\text { type } \\
\text { Xanthomonas spp. pathogenicity }\end{array}$ & Drug resistance & 0.93854 \\
\hline M00660 & 0.10312 & 3.36307 & 5.02732 & 0.79335 & $\begin{array}{l}\text { signature, T3SS and effectors } \\
\text { Hk1-Rrp1 (glycerol uptake and }\end{array}$ & Plant pathogenicity & 0.85511 \\
\hline M00662 & 0.03522 & 0.99994 & 4.82742 & -0.9501 & $\begin{array}{l}\text { utilization) two-component regulatory } \\
\text { system } \\
\text { Tetracycline resistance, TetA }\end{array}$ & $\begin{array}{l}\text { Two-component } \\
\text { regulatory system } \\
\text { Drug efflux }\end{array}$ & 0.68301 \\
\hline M00668 & 2.43527 & 14.3833 & 2.56224 & 3.07198 & transporter & $\begin{array}{l}\text { transporter/pump } \\
\text { Saccharide, polyol, }\end{array}$ & 0.43277 \\
\hline M00669 & 5.38999 & 6.73085 & 0.32051 & 2.59942 & $\begin{array}{l}\text { gamma-Hexachlorocyclohexane } \\
\text { transport system }\end{array}$ & $\begin{array}{l}\text { and lipid transport } \\
\text { system } \\
\text { Saccharide, polyol, } \\
\text { and lipid transport }\end{array}$ & 0.98182 \\
\hline M00670 & 5.38999 & 6.73085 & 0.32051 & 2.59942 & Mce transport system & system & 0.98182 \\
\hline M00672 & 3.12426 & 4.43008 & 0.50382 & 1.91731 & $\begin{array}{l}\text { cycteine }+ \text { valine }=>\text { penicillin } \\
\text { Cephamycin } C \text { biosynthesis, }\end{array}$ & secondary metabolites & 0.76736 \\
\hline M00673 & 3.16808 & 5.87067 & 0.88991 & 2.17612 & $\begin{array}{l}\text { aminoadipate }+ \text { cycteine }+ \text { valine }=> \\
\text { cephamycin } C\end{array}$ & $\begin{array}{l}\text { Biosynthesis of } \\
\text { secondary metabolites }\end{array}$ & 0.70887 \\
\hline M00676 & 49.6528 & 80.2215 & 0.69211 & 6.02097 & PI3K-Akt signaling & Cell signaling & 0.80158 \\
\hline M00677 & 240.648 & 163.361 & -0.5589 & 7.65824 & Wnt signaling & Cell signaling & 0.98489 \\
\hline M00678 & 320.862 & 193.286 & -0.7312 & 8.00604 & Hedgehog signaling & Cell signaling & 0.65391 \\
\hline M00679 & 1.12263 & 4.10355 & 1.86999 & 1.38576 & BMP signaling & Cell signaling & 0.99985 \\
\hline M00680 & 1.77943 & 7.8706 & 2.14506 & 2.27053 & TGF-beta signaling & Cell signaling & 0.80894 \\
\hline M00681 & 0.68157 & 8.14209 & 3.57846 & 2.14138 & Activin signaling & Cell signaling & 0.99295 \\
\hline M00682 & 330.126 & 266.093 & -0.3111 & 8.2197 & Notch signaling & Cell signaling & 0.28742 \\
\hline M00683 & 98.9315 & 139.261 & 0.49329 & 6.89598 & Hippo signaling & Cell signaling & 0.76319 \\
\hline M00684 & 0.86096 & 12.155 & 3.81947 & 2.70221 & JAK-STAT signaling & Cell signaling & 0.98142 \\
\hline M00685 & 0.30594 & 2.61633 & 3.09621 & 0.54709 & Apoptotic machinery & Cell signaling & 0.86988 \\
\hline M00686 & 35.9812 & 23.2132 & -0.6323 & 4.88739 & Toll-like receptor signaling & Cell signaling & 0.98639 \\
\hline M00687 & 167.556 & 233.193 & 0.47688 & 7.64656 & MAPK (ERK1/2) signaling & Cell signaling & 0.59631 \\
\hline M00688 & 60.3747 & 82.9636 & 0.45853 & 6.16328 & MAPK (JNK) signaling & Cell signaling & 0.96255 \\
\hline M00689 & 66.2285 & 81.4283 & 0.29808 & 6.2061 & MAPK (p38) signaling & Cell signaling & 0.98546 \\
\hline M00690 & 12.0071 & 38.8459 & 1.69387 & 4.66826 & $\begin{array}{l}\text { MAPK (ERK5) signaling } \\
\text { DNA damage-induced cell cycle }\end{array}$ & Cell signaling & 0.31907 \\
\hline M00691 & 33.6389 & 96.7599 & 1.52428 & 6.02679 & checkpoints & Cell signaling & 0.75089 \\
\hline M00692 & 602.57 & 385.548 & -0.6442 & 8.94854 & Cell cycle - G1/S transition & Cell signaling & 0.77578 \\
\hline M00693 & 1326.36 & 845.64 & -0.6494 & 10.0848 & Cell cycle - G2/M transition & Cell signaling & 0.70036 \\
\hline M00694 & 213.451 & 448.365 & 1.07077 & 8.37028 & cGMP signaling & Cell signaling & 0.87301 \\
\hline
\end{tabular}




\begin{tabular}{|c|c|c|c|c|c|c|c|}
\hline M00695 & 502.286 & 594.522 & 0.24322 & 9.0991 & $\begin{array}{l}\text { cAMP signaling } \\
\text { Multidrug resistance, efflux pump }\end{array}$ & Cell signaling & 0.61246 \\
\hline M00696 & 0.25551 & 51.4409 & 7.6534 & 4.69199 & $\begin{array}{l}\text { AcrEF-TolC } \\
\text { Multidrug resistance, efflux pump }\end{array}$ & Drug resistance & 0.00104 \\
\hline M00697 & 0.25551 & 51.4409 & 7.6534 & 4.69199 & $\begin{array}{l}\text { MdtEF-TolC } \\
\text { Multidrug resistance, efflux pump }\end{array}$ & $\begin{array}{l}\text { Drug resistance } \\
\text { Drug efflux }\end{array}$ & 0.00104 \\
\hline M00701 & 0.0901 & 0.47944 & 2.41176 & -1.8121 & $\begin{array}{l}\text { EmrAB } \\
\text { Macrolide resistance, MacAB-TolC }\end{array}$ & $\begin{array}{l}\text { transporter/pump } \\
\text { Drug efflux }\end{array}$ & 0.93854 \\
\hline M00709 & 0.45062 & 58.9662 & 7.03182 & 4.8928 & $\begin{array}{l}\text { transporter } \\
\text { Fluoroquinolone resistance, efflux pump }\end{array}$ & $\begin{array}{l}\text { transporter/pump } \\
\text { Drug efflux }\end{array}$ & 0.0113 \\
\hline M00713 & 0.05594 & 3.63104 & 6.02037 & 0.88244 & LfrA & transporter/pump & 0.65113 \\
\hline M00714 & 0.05594 & 3.63104 & 6.02037 & 0.88244 & Multidrug resistance, efflux pump QacA & Drug resistance & 0.65113 \\
\hline M00717 & 0.04125 & 0.87559 & 4.40783 & -1.1253 & $\begin{array}{l}\text { Multidrug resistance, efflux pump NorA } \\
\text { Multidrug resistance, efflux pump }\end{array}$ & $\begin{array}{l}\text { NA } \\
\text { Drug efflux }\end{array}$ & 0.51344 \\
\hline M00720 & 0.25551 & 51.4409 & 7.6534 & 4.69199 & $\begin{array}{l}\text { VexEF-TolC } \\
\text { Cationic antimicrobial peptide (CAMP) }\end{array}$ & transporter/pump & 0.00104 \\
\hline M00721 & 0.45245 & 8.30811 & 4.1987 & 2.13102 & $\begin{array}{l}\text { resistance, arnBCADTEF operon } \\
\text { Cationic antimicrobial peptide (CAMP) } \\
\text { resistance, phosphoethanolamine }\end{array}$ & Drug resistance & 0.91951 \\
\hline M00723 & 0.19511 & 7.52526 & 5.26935 & 1.94867 & $\begin{array}{l}\text { transferase EptB } \\
\text { Cationic antimicrobial peptide (CAMP) }\end{array}$ & Drug resistance & 0.63992 \\
\hline M00724 & 0.19511 & 7.52526 & 5.26935 & 1.94867 & $\begin{array}{l}\text { resistance, palmitoyl transferase PagP } \\
\text { Cationic antimicrobial peptide (CAMP) } \\
\text { resistance, lysyl-phosphatidylglycerol }\end{array}$ & Drug resistance & 0.63992 \\
\hline M00726 & 0.08228 & 0.50694 & 2.62319 & -1.7631 & $\begin{array}{l}\text { (L-PG) synthase MprF } \\
\text { Cationic antimicrobial peptide (CAMP) } \\
\text { resistance, N-acetylmuramoyl-L- }\end{array}$ & Drug resistance & 0.90576 \\
\hline M00727 & 1.61967 & 1.32941 & -0.2849 & 0.56026 & $\begin{array}{l}\text { alanine amidase AmiA and AmiC } \\
\text { Cationic antimicrobial peptide (CAMP) } \\
\text { resistance, envelope protein folding and }\end{array}$ & Drug resistance & 0.99553 \\
\hline M00728 & 0.81291 & 18.8832 & 4.53786 & 3.29984 & $\begin{array}{l}\text { degrading factors DegP and DsbA } \\
\text { Fluoroquinolone resistance, gyrase- }\end{array}$ & Drug resistance & 0.97584 \\
\hline M00729 & 32.3816 & 29.1144 & -0.1534 & 4.94242 & $\begin{array}{l}\text { protecting protein Qnr } \\
\text { Nocardicin A biosynthesis, L-pHPG + }\end{array}$ & $\begin{array}{l}\text { Drug resistance } \\
\text { Biosynthesis of }\end{array}$ & 0.95402 \\
\hline M00736 & 0.23778 & 0.23778 & 0 & -2.0723 & arginine + serine $=>$ nocardicin $\mathrm{A}$ & $\begin{array}{l}\text { secondary metabolites } \\
\text { Other carbohydrate }\end{array}$ & 0.93854 \\
\hline M00740 & 10654.2 & 7320.42 & -0.5414 & 13.1337 & $\begin{array}{l}\text { Methylaspartate cycle } \\
\text { Propanoyl-CoA metabolism, propanoyl- }\end{array}$ & $\begin{array}{l}\text { metabolism } \\
\text { Other carbohydrate }\end{array}$ & 0.39254 \\
\hline M00741 & 329.991 & 327.273 & -0.0119 & 8.36033 & $\begin{array}{l}\mathrm{CoA}=>\text { succinyl-CoA } \\
\text { Aminoglycoside resistance, protease }\end{array}$ & metabolism & 0.93979 \\
\hline M00742 & 1822.72 & 3393.96 & 0.89688 & 11.3489 & $\begin{array}{l}\text { FtsH } \\
\text { Aminoglycoside resistance, protease }\end{array}$ & Drug resistance & 0.68087 \\
\hline M00743 & 1.29027 & 1.42758 & 0.1459 & 0.44247 & $\begin{array}{l}\text { HtpX } \\
\text { Cationic antimicrobial peptide (CAMP) }\end{array}$ & Drug resistance & 0.94388 \\
\hline M00744 & 0.19511 & 7.52526 & 5.26935 & 1.94867 & $\begin{array}{l}\text { resistance, protease PgtE } \\
\text { Imipenem resistance, repression of }\end{array}$ & Drug resistance & 0.63992 \\
\hline M00745 & 0.34311 & 2.09679 & 2.61146 & 0.28682 & $\begin{array}{l}\text { porin OprD } \\
\text { Erythromycin resistance, macrolide 2'- }\end{array}$ & Drug resistance & 0.99806 \\
\hline M00760 & 0.51556 & 6.06296 & 3.55582 & 1.71776 & $\begin{array}{l}\text { phosphotransferase I MphA } \\
\text { Undecaprenylphosphate alpha-L-Ara4N } \\
\text { biosynthesis, UDP-GlcA => } \\
\text { Undecaprenyl phosphate alpha-L- }\end{array}$ & Drug resistance & 0.14046 \\
\hline M00761 & 0.25733 & 0.78286 & 1.60512 & -0.9432 & $\begin{array}{l}\text { Ara4N } \\
\text { Ornithine biosynthesis, mediated by }\end{array}$ & $\begin{array}{l}\text { NA } \\
\text { Arginine and proline }\end{array}$ & 0.98544 \\
\hline M00763 & 1.31453 & 0.86361 & -0.6061 & 0.1231 & LysW, glutamate $=>$ ornithine & metabolism & 0.77096 \\
\hline
\end{tabular}




\section{APPENDIX 4: MA PLOT BETWEEN UPPER AND LOWER STATIONS}

Differential expression analysis between the upper and lower estuary stations for (A) station 20 versus station 70, (B) station 20 versus station 120 and (C) station 20 versus station 180.
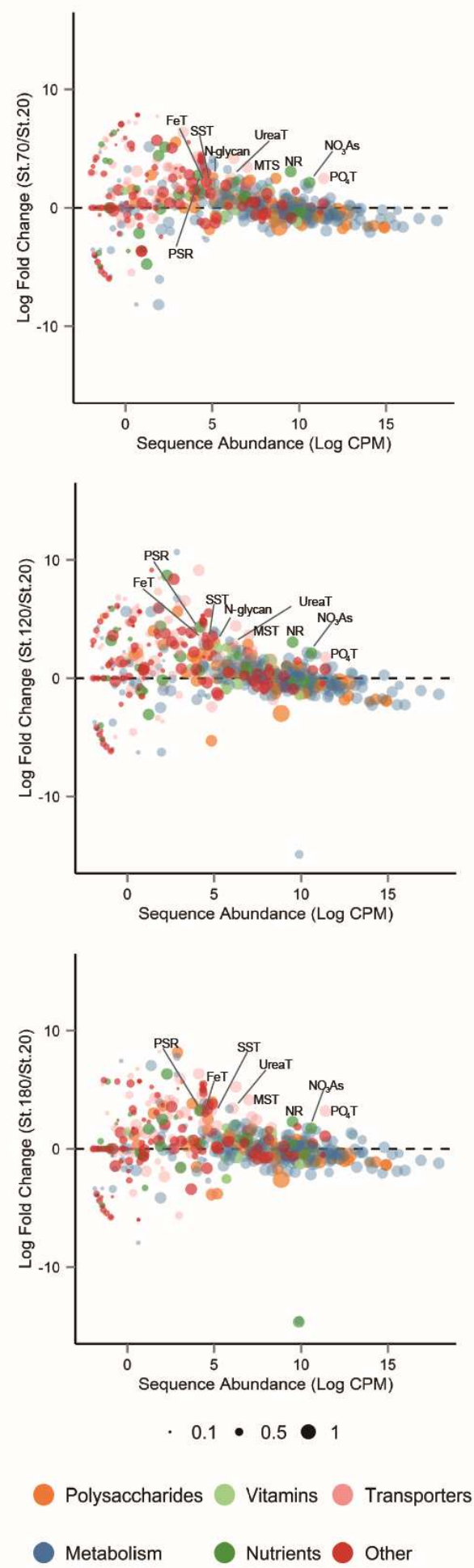


\section{APPENDIX 5: HEATMAP FOR EXPRESSION PROFILES}

Heatmap for the expression profiles based on KEGG clas 3 between a) station 20 and station 70 , b) station 20 and station 120, c) station 20 and station 180. Each row represents the expression level of a KEGG clas3 with warmer color (positive fold change) indicating overrepresentation in the lower estuary stations (station 70,120,180) and cooler color (negative fold change) indicating over-representation at station 20 .

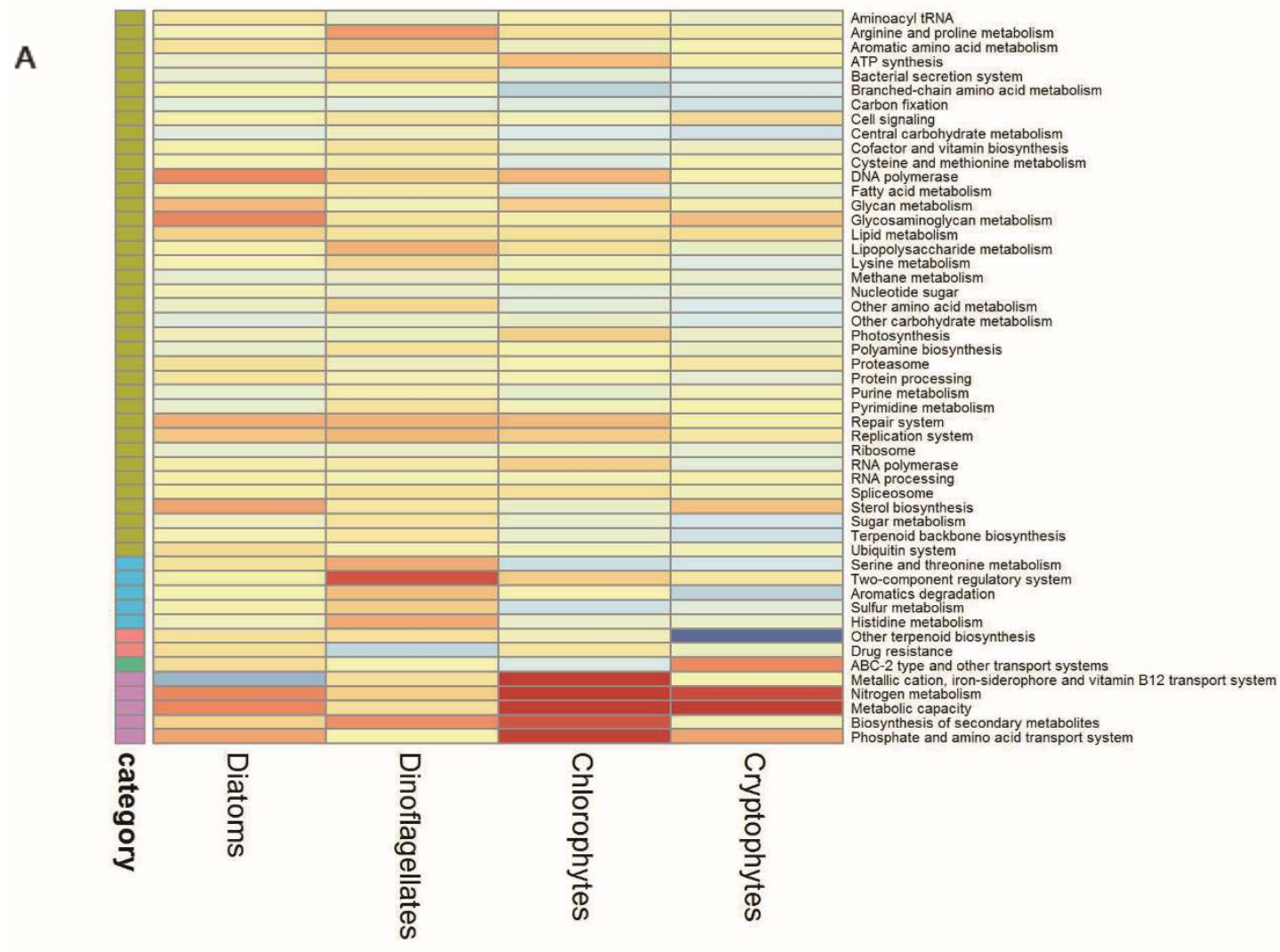


B

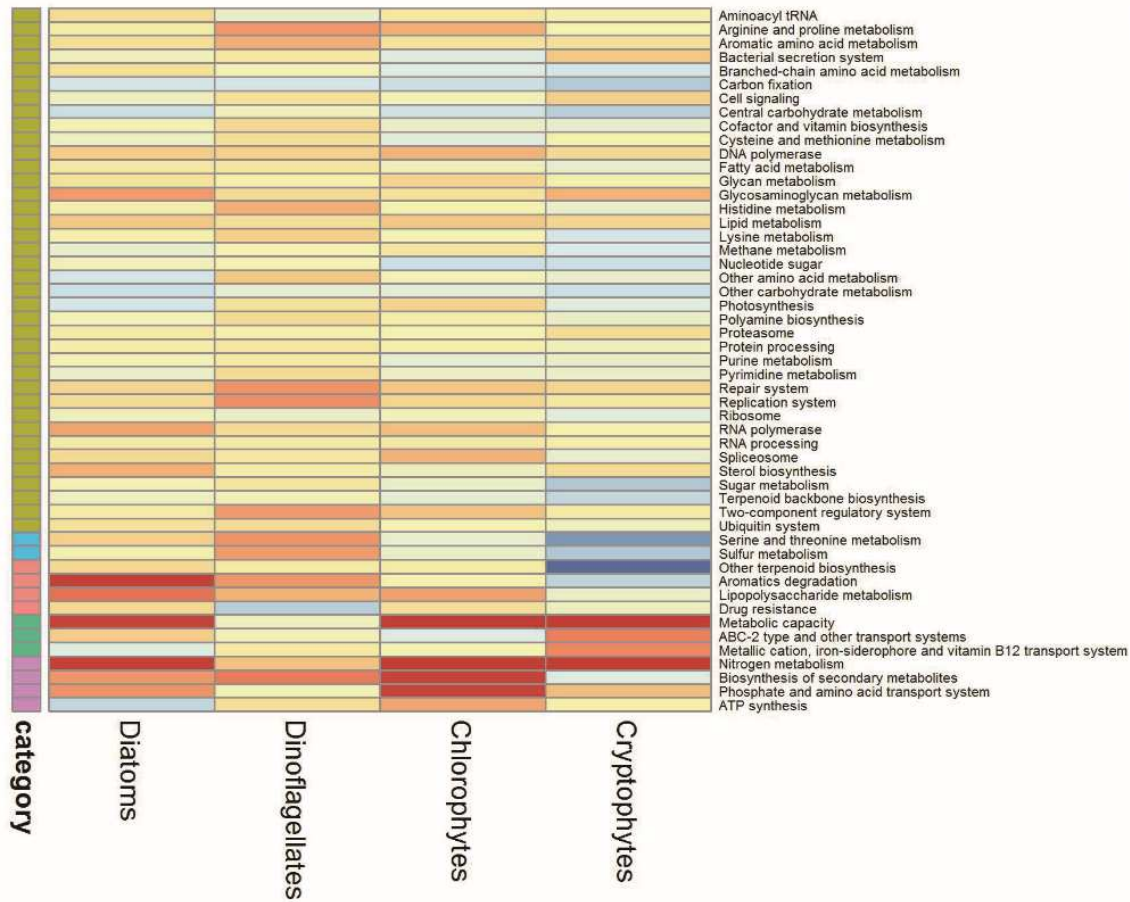

C

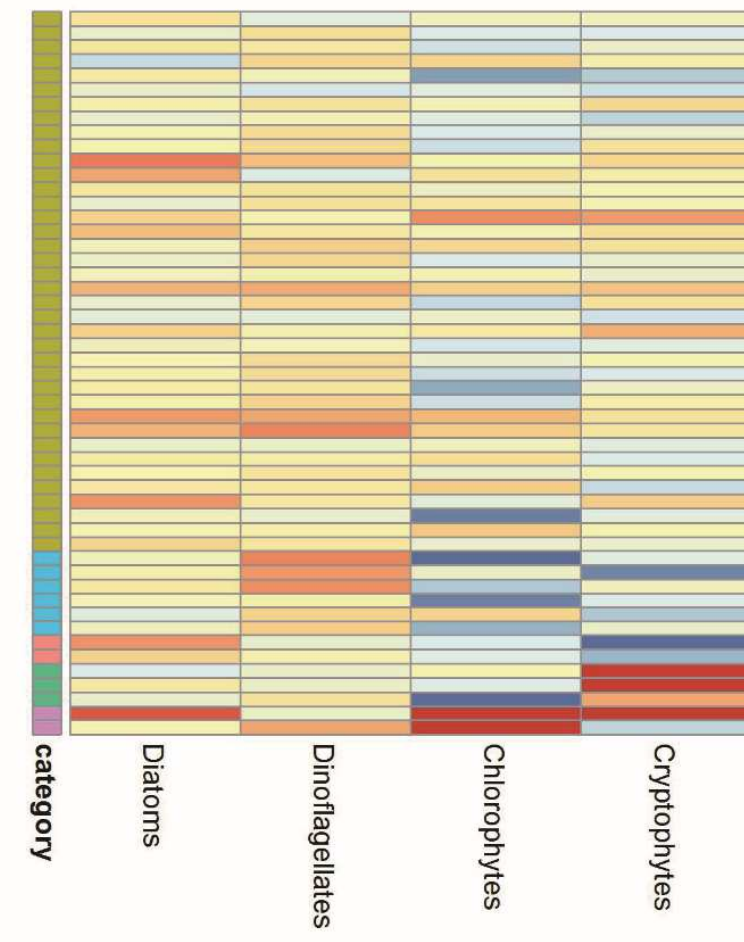

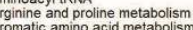

Tranchede-chis ain amino acid metabolism

Cell signaling

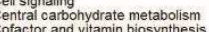

Cysteine and methionine metabolism

Cysteine and me
DNA polymerase
Drug resistance

atty acid metabolism

(ycosaminogliscan metabolism

Lipid metabolism me metabolism

ysine metabolism
Methane metabolism

Nitrogen metabolism

Ther carbohydrate metabolism

and amino acid transport system

Peasome

protein roceessin

Pyrimidine metabolism

Repair system

Ribosome
RNA polymerase
RNA processing

pliceosome

Sterol biosynthesis
Terpenoid backbone biosynthesis
Two-component regulatory system

quitin system

Sulfur metabolism
Serine and threonine metabolism

Serine and threo
Nucleotide sugar
Photosnnthesis

Histidine metabolism
Other termenoid biosynthesis

Jar

BC-2 type and other tran Metabolic capacity Metabolic capacity
Aromatics degradation

Log FC:

$\leq-4$

category

Chloro_up

Crypto_up

Diatom_up

Dino_up

Low_variance 


\section{REFERENCES}

Anderson, M.J. \& Walsh, D.C.I., 2013. PERMANOVA, ANOSIM, and the Mantel test in the face of heterogeneous dispersions: What null hypothesis are you testing? Ecological Monographs, 83(4), pp.557-574. Available at: http://doi.wiley.com/10.1890/12-2010.1 [Accessed November 1, 2016].

Andrews, S., 2010. FastQC: a quality control tool for high throughput sequence data. Available at: http://www.bioinformatics.babraham.ac.uk/projects/fastqc/.

Azam, F. et al., 1983. The Ecological Role of Water-Column Microbes in the Sea . Marine Ecology Progress Series, 10, pp.257-263.

Brussaard, C.P.D., 2003. Viral control of phytoplankton populations--a review. The Journal of eukaryotic microbiology, 51(2), pp.125-38.

Carstensen, J., Henriksen, P. \& Heiskanen, A.-S., 2007. Summer algal blooms in shallow estuaries: Definition, mechanisms, and link to eutrophication. Limnology and Oceanography, 52(1), pp.370384.

Cira, E.K. et al., 2016. Effects of Nitrogen Availability and Form on Phytoplankton Growth in a Eutrophied Estuary (Neuse River Estuary, NC, USA) C. J. Gobler, ed. PLOS ONE, 11(8), p.e0160663.

Clarke, K.R. \& Warwick, R.M., 2001. Change in marine communities. An approach to statistical analysis and interpretation. Natural Environment Research Council, pp.1-172.

Cloern, J., 2001. Our evolving conceptual model of the coastal eutrophication problem. Marine Ecology Progress Series, 210, pp.223-253.

Cooper, E.D. et al., 2014. Metatranscriptome profiling of a harmful algal bloom. Harmful Algae, 37, pp.75-83.

Cooper, M.B. \& Smith, A.G., 2015. Exploring mutualistic interactions between microalgae and bacteria in the omics age. Current Opinion in Plant Biology, 26, pp.147-153.

Croft, M.T. et al., 2005. Algae acquire vitamin B12 through a symbiotic relationship with bacteria. Nature, 438(November), pp.90-93.

Day, J.W. et al., 2012. Estuarine Ecology 2nd ed., New York, NY: John Wiley.

Delbarre-Ladrat, C. et al., 2014. Exopolysaccharides produced by marine bacteria and their applications as glycosaminoglycan-like molecules. Frontiers in Chemistry, 2(October), pp.1-15.

Demir, E. et al., 2008. Assessment of Microzooplankton Grazing on Heterosigma akashiwo Using a Species- Specific Approach Combining Quantitative Real-Time PCR (QPCR) and Dilution Methods. Microbial Ecology, 55(4), pp.583-594.

Fawcett, S.E. \& Ward, B.B., Phytoplankton succession and nitrogen utilization during the development of an upwelling bloom. Marine Ecology Progress Series, 428, pp.13-31.

Gifford, S.M. et al., 2012. Expression patterns reveal niche diversification in a marine microbial 
assemblage. The ISME Journal, 7(2), pp.281-298.

Giordano, M., Beardall, J. \& Raven, J. a, 2005. CO2 concentrating mechanisms in algae: mechanisms, environmental modulation, and evolution. Annual review of plant biology, 56, pp.99-131.

Graham, S. \& Strom, S., 2010. Growth and grazing of microzooplankton in response to the harmful alga Heterosigma akashiwo in prey mixtures. Aquatic Microbial Ecology, 59(2), pp.111-124.

Hall, N.S. et al., 2012. Effects of climatic variability on phytoplankton community structure and bloom development in the eutrophic , microtidal, New River Estuary, North Carolina, USA. Estuarine, Coastal and Shelf Science, 117, pp.70-82.

Hall, N.S. \& Pearl, H., 2011. Vertical migration patterns of phytoflagellates in relation to light and nutrient availability in a shallow microtidal estuary. Marine Ecology Progress Series, 425, pp.1-19.

Hatch, M.D. \& Slack, C.R., 1968. A new enzyme for the interconversion of pyruvate and phosphopyruvate and its role in the $\mathrm{C} 4$ dicarboxylic acid pathway of photosynthesis. Biochem $\mathrm{J}$, 106(1), pp.141-146.

Howarth, R.W., Billen, G. \& Swaney, D., 1997. Regional nitrogen budgets and riverine N and P fluxes for the drainages to the North Atlantic Ocean: natural and human influences. Oceanographic Literature Review, 5(44), p.448.

Jones, P.M. \& George, A.M., 2004. The ABC transporter structure and mechanism: perspectives on recent research. Cellular and molecular life sciences : CMLS, 61(6), pp.682-99.

Kang, L.-K. et al., 2007. Influences of nitrogen deficiency on the transcript levels of ammonium transporter, nitrate trans ... Phycologia, pp.521-533.

Keeling, P.J. et al., 2014. The Marine Microbial Eukaryote Transcriptome Sequencing Project (MMETSP): Illuminating the Functional Diversity of Eukaryotic Life in the Oceans through Transcriptome Sequencing. PLoS Biology, 12.

Kennish, M.J. \& Paerl, H.W., 2010. Coastal lagoons : critical habitats of environmental change, Taylor $\&$ Francis.

Langfelder, P. \& Horvath, S., 2008. WGCNA: an R package for weighted correlation network analysis. BMC bioinformatics, $9(1)$, p.559.

Li, H. et al., 2009. The Sequence Alignment/Map format and SAMtools. Bioinformatics (Oxford, England), 25(16), pp.2078-9.

Liu, Z. et al., 2015. Changes in gene expression of Prymnesium parvum induced by nitrogen and phosphorus limitation. Frontiers in microbiology, 6, p.631.

Maheswari, U. et al., 2010. Digital expression profiling of novel diatom transcripts provides insight into their biological functions. Genome biology, 11(8), p.R85.

Mallin, M.A. \& Paerl, H.W., 1992. Effects of variable irradiance on phytoplankton productivity in shallow estuaries. Limnology and Oceanography, 37(1), pp.54-62. A 
Marchetti, A. et al., 2012. Comparative metatranscriptomics identifies molecular bases for the physiological responses of phytoplankton to varying iron availability. Proceedings of the National Academy of Sciences, 109(6), pp.E317-E325.

Nielsen, R. et al., 2005. A Scan for Positively Selected Genes in the Genomes of Humans and Chimpanzees. PLoS Biology, 3(6), p.e170.

Nixon, S.W., 1995. Coastal marine eutrophication: A definition, social causes, and future concerns. Ophelia, 41(1), pp.199-219.

Paerl, H.W., 2006. Assessing and managing nutrient-enhanced eutrophication in estuarine and coastal waters: Interactive effects of human and climatic perturbations. Ecological Engineering, 26, pp.4054.

Paerl, H.W. et al., 1998. Ecosystem responses to internal and watershed organic matter loading: consequences for hypoxia in the eutrophying Neuse River Estuary, North Carolina, USA. Marine Ecology Progress Series, 166, pp.17-25.

Paerl, H.W., Hall, N.S., Peierls, B.L. \& Rossignol, K.L., 2014. Evolving Paradigms and Challenges in Estuarine and Coastal Eutrophication Dynamics in a Culturally and Climatically Stressed World. Estuaries and Coasts, 37(2), pp.243-258.

Paerl, H.W., Hall, N.S., Peierls, B.L., Rossignol, K.L., et al., 2014. Hydrologic Variability and Its Control of Phytoplankton Community Structure and Function in Two Shallow, Coastal, Lagoonal Ecosystems: The Neuse and New River Estuaries, North Carolina, USA. Estuaries and Coasts, 37(S1), pp.31-45.

Paerl, H.W. et al., 1995. Nitrogen loading sources and eutrophication of the Neuse River Estuary, North Carolina: Direct and indirect roles of atmospheric deposition. Rep, 291.

Paerl, H.W. et al., 2010. Phytoplankton community indicators of short- and long-term ecological change in the anthropogenically and climatically impacted neuse river estuary, North Carolina, USA. Estuaries and Coasts, 33, pp.485-497.

Peierls, B.L., Hall, N.S. \& Paerl, H.W., 2012. Non-monotonic Responses of Phytoplankton Biomass Accumulation to Hydrologic Variability: A Comparison of Two Coastal Plain North Carolina Estuaries. Estuaries and Coasts, 35(6), pp.1376-1392.

Piehler, M.F. et al., 2004. Impacts of inorganic nutrient enrichment on phytoplankton community structure and function in Pamlico Sound, NC, USA. Estuarine, Coastal and Shelf Science, 61, pp.197-209.

Pinckney, J.L. et al., 1998. Annual cycles of phytoplankton community-structure and bloom dynamics in the Neuse River Estuary, North Carolina. Marine Biology, 131(2), pp.371-381.

Pinckney, J.L. et al., 1997. Environmental controls of phytoplankton bloom dynamics in the Neuse River Estuary, North Carolina, U.S.A. Canadian Journal of Fisheries and Aquatic Sciences, 54(11), pp.2491-2501.

Pinckney, J.L. et al., 1996. Flow scintillation counting of 14 C-labeled microalgal photosynthetic pigments. Journal of Plankton Research, 18(10), pp.1867-1880. 
Reed, R.E. et al., 2004. Seasonal physical-chemical structure and acoustic Doppler current profiler flow patterns over multiple years in a shallow, stratified estuary, with implications for lateral variability. Estuarine, Coastal and Shelf Science, 60(4), pp.549-566.

Reinfelder, J.R., Kraepiel, A.M. \& Morel, F.M., 2000. Unicellular C4 photosynthesis in a marine diatom. Nature, 407(6807), pp.996-9.

Rinta-Kanto, J.M. et al., 2012. Bacterial community transcription patterns during a marine phytoplankton bloom. Environmental Microbiology, 14, pp.228-239.

Robertson, G. et al., 2010. De novo assembly and analysis of RNA-seq data. Nature methods, 7(11), pp.909-12. Available at: http://dx.doi.org/10.1038/nmeth.1517 [Accessed August 7, 2015].

Robinson, M.D., McCarthy, D.J. \& Smyth, G.K., 2009. edgeR: A Bioconductor package for differential expression analysis of digital gene expression data. Bioinformatics, 26(1), pp.139-140.

Robinson, M.D. \& Oshlack, A., 2010. A scaling normalization method for differential expression analysis of RNA-seq data. Genome biology, 11, p.R25.

Schruth, D., 2013. caroline: A Collection of Database, Data Structure, Visualization, and Utility Functions for R. Available at: http://cran.r-project.org/package=caroline.

Seymour, J.R. et al., 2017. Zooming in on the phycosphere: the ecological interface for phytoplanktonbacteria relationships. Nature Microbiology, 2(May), p.17065.

Sharp, J.H. et al., 1984. Estuarine Interaction of Nutrients, Organics, and Metals: A Case Study in the Delaware Estuary. The Estuary as a Filter, Academic Press, Orlando FL. 1984. P 241-258, 10 fig, 23 ref. NA 80 AA-D-00106., pp.241-258.

Simpson, J.T. et al., 2009. ABySS: a parallel assembler for short read sequence data. Genome research, 19(6), pp.1117-23.

Smayda, T.J., 1997. Harmful algal blooms: Their ecophysiology and general relevance to phytoplankton blooms in the sea. Limnology and Oceanography, 42(5_part_2), pp.1137-1153.

Smith, G.J., Zimmerman, R.C. \& Alberte, R.S., 1992. Molecular and physiological responses of diatoms to variable levels of irradiance and nitrogen availability: Growth of Skeletonema costatum in simulated upwelling conditions. Limnology and Oceanography, 37(5), pp.989-1007.

Song, B. \& Ward, B.B., 2007. MOLECULAR CLONING AND CHARACTERIZATION OF HIGHAFFINITY NITRATE TRANSPORTERS IN MARINE PHYTOPLANKTON. Journal of Phycology, 43(3), pp.542-552.

Twomey, L.J., Piehler, M.F. \& Paerl, H.W., 2005. Phytoplankton uptake of ammonium, nitrate and urea in the Neuse River Estuary, NC, USA. Hydrobiologia, 533(1-3), pp.123-134.

Valdes-Weaver, L.M. et al., 2006. Long-term temporal and spatial trends in phytoplankton biomass and class-level taxonomic composition in the hydrologically variable Neuse-Pamlico estuarine continuum, North Carolina, U.S.A. Limnology and Oceanography, 51(3), pp.1410-1420. 
Walz, N. \& Welker, M., 1998. Plankton Development in a Rapidly Flushed Lake in the River Spree System (Neuendorfer See, Northeast Germany). J Plankton Res, Vol 20(Iss 11), pp.2071-2087.

Wear, E.K. et al., 2015. Roles of diatom nutrient stress and species identity in determining the short- and long-term bioavailability of diatom exudates to bacterioplankton. Marine Chemistry, 177, pp.335348.

Wei, Y. et al., 2001. High-density microarray-mediated gene expression profiling of Escherichia coli. Journal of bacteriology, 183(2), pp.545-56.

Welschmeyer, N.A., 1994. Fluorometric analysis of chlorophyll a in the presence of chlorophyll b and pheopigments. Limnology and Oceanography, 39(8), pp.1985-1992. 